\title{
Parent-Adolescent Relationships and Adolescent Pubertal Development
}

Layne Dee Bennion

Vernal, Utah

B.S., Utah State University, 1985

M.S., Utah State University, 1989

A Dissertation presented to the Graduate Faculty of the University of Virginia

in Candidacy for the Degree of

Doctor of Philosophy

\author{
Department of Psychology \\ University of Virginia
}

August 1995

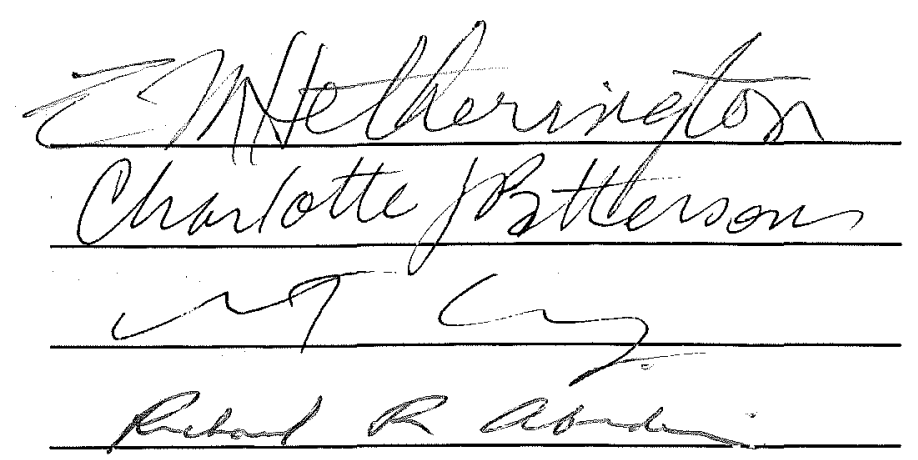


PSYCH

Diss.

Psych.

1995

. 846 
(C) Copyright by

Layne Dee Bennion

All rights reserved

August 1995 


\section{Acknowledgements}

First I would like to thank my wife, Rebecca, for her patience, love, support and affection. It has been a long, long, long journey. Gerald Adams, my academic mentor and father-figure, took a risk in helping an earnest, but very quiet student. He opened my mind to possibilities and helped build my confidence. Ray Bingham was an important ally in those early years.

The support of more recent collegues has been important to me: the BAS staff for their humor and concern, the department of psychology at Wilford Hall.

Finally acknowledgement is due to my family and parents who have been supportive of my efforts in school. They raised their children with a love of learning and a respect for work. 
Abstract

This study investigated the longitudinal and crosssectional relationship between three composite measures of parenting behaviors (negativity, positivity and control) and the pubertal development of adolescents. Approximately 400 families consisting of a mother, father and adolescents comprised the sample. Data was collected in two waves two to two-and-one-half years apart. Important grouping variables included family type (stepfamilies and nondivorced families), adolescent gender and timing of puberty for females. Exploratory analyses were conducted to compare biological parent-adolescent relationships versus stepparent-child relationships. Behavioral composites of each parent's behavior toward the target adolescent were constructed based on mother, father, adolescent and observer reports.

Curvilinear relationships between the parenting composites and pubertal development were expected and directly tested via difference scores. For example, negativity was hypothesized to increase during early pubertal development and decrease during later stages of pubertal development: Support for curvilinear patterns was found for maternal negativity and somewhat for paternal positivity and control in some family groups. A consistent and robust wave effect indicated increased parental negativity, decreased positivity and decreased control over 
time. Family type differences indicated higher negativity and lower postivity for adolescents in stepfamilies as compared to teenagers in nondivorced homes. The importance of including biologically versus nonbiologically related dyads when examining family relationships was supported in a variety of ways. 


\section{Parent-Adolescent Relationships and \\ Adolescent Pubertal Development}

Early adolescence, perhaps more than any other period in human life aside from early childhood, is a period of maximal change: biologically, physically, cognitively and socially. Aspects of this process are obvious, not only to adolescent themselves, but also to their parents and to society around them. Pubertal maturation marks the beginning of a developmental transition from childhood to adulthood.

Puberty is characterized not only by physical transformations associated with biological maturation, but also with shifts in cognitive functioning as adolescents move into formal operations, notable changes in the selfsystem and alterations in social relationships. Although family relationships continue to play an important role in adolescent development, other social relationships in the peer group, school and neighborhood become increasingly salient.

It is not just in quantitative changes in time spent with parents that alterations in the parent-child relationship occur, qualitative shifts also are found as the teenager begins to deal with the normative challenges of adolescence associated with increasing independence. There is a shift in parent-adolescent relationships from the 
parents organizing, controlling and making decisions about the child's activities and well-being to an increase in autonomy and self-control as teenagers gain greater responsibility for their own lifestyles as they mature (Steinberg, 1990a; Grotevant \& Cooper, 1986).

As this shift in adolescent autonomy occurs affective changes in warmth, negativity and conflict in the parentchild relationship have been found (e.g., Hill, Holmbeck, Marlow, Green \& Lynch, 1985a, 1985b; Mekos, 1991; Steinberg, 1981; Anderson, Hetherington \& Clingempeel, 1989). Moreover parent may give up attempts to directly control their children's behavior and rely on monitoring and more indirect supervision of their adolescents activities.

This paper will focus on changes in parent-adolescent relationships associated with physical maturation. Theories Predicting Changes in Parent-Adolescent Relations

There are a number of prominent developmental theories that attempt to forecast changes in parent-adolescent relations and illuminate the forces promoting these reorganizations.

Freudian psychodynamic theory. Freudian theory proposed that puberty produces a rupture in parent-child relations because of the reawakening sexual instinct in the early adolescent. Puberty revitalizes sexual drives and 
Parent-Adolescent Relations and Puberty

reactivates the Oedipal conflict. The resurgence of these conscious and unconscious impulses and conflicts leads ultimately to detachment from parental objects (Freud, 1958). Emotional detachment is made possible by increased fear, rejection and hostility toward parents. Parents react to this by excessive control attempts (Freud, 1936). Given the heightened control attempts by parents, the increased parent-adolescent hostility and the underlying sexual tensions, one would predict increases in parent-adolescent conflicts.

Freudian theory has been criticized, however, by Steinberg (1989). Psychoanalytic theory predicts, in particular, increased conflict between sons and mothers and between fathers and daughters. The available data points toward heightened conflict with mothers whether the adolescent is male or female.

Lewin Field Theory. Another developmental theory, Lewin's field theory, describes adolescents as "marginal men [and women]" (Muuss, 1982) stuck between the life space available to children and that of adults. Adolescents are expected not behave as children yet aren't given the responsibilities and freedoms adults have. Puberty brings with it sexual and physical maturity and parents begin to expect more responsible and adult-like behavior (Brooks-Gunn 
Parent-Adolescent Relations and Puberty

\& Zahaykevich, 1989). However, these expectations apply only to socially or culturally acceptable teenage functioning and usually excludes sexual behavior which has a strong positive valence for an adolescent. Because of the shifting life space and associated valances, unfamiliar situations, a still-developing cognitive structure and sense of self still in transition, the adolescent experiences increased emotional tensions and periodic aggression leading to conflict with their parents.

Evolutionary Model. Steinberg (1988, 1989) has suggested another theoretical basis for increased emotional distance between maturing adolescents and their parents-evolution. Among virtually all nonhuman primates who live in groups, emigration from the family group takes place at about the time of puberty (Caine, 1986). Emigration leads to increased reproductive fitness because it minimizes inbreeding and increases genetic diversity. Historical work (Katz, 1975) and cross-cultural work (Cohen, 1964) both suggest that emigration from the family group was common at puberty in the past and is traditional among diverse cultures. The economic state and educational demands in contemporary westernized societies have made leaving parents at puberty nearly impossible. The modern analogue of physical emigration may be parent-child distancing in the 
form of increased conflict, increased adolescent autonomy and decreased family cohesion and warmth.

Such biologically based theories include assumptions that biological changes in adolescence coincide with increased difficulties in parent-adolescent behavior. There is considerable alteration in hormone secretion during puberty (Tanner, 1970) with increases in concentrations of the pituitary hormones called gonadotropins, specifically the luteinizing hormone and follicle-stimulating hormone. The gonads respond by synthesizing and secreting sex steroids (androgens and estrogens). Hormonal changes which are normative during puberty have been linked to an increase in the frequency of negative emotions, such as depression or anger, to higher emotional lability, decreases in impulse control, less frustration tolerance and possibly a rise in aggression (Brooks-Gunn \& Zahaykevich, 1989; Inoff-Germain, Arnold, Nottelmann, Susman, Cutler, Chrousos, 1988; Olweus, Block \& Radke-Yarrow, 1986; Brooks-Gunn \& Warren, 1989). These changes may increase the probabilities that the adolescent behaves more negatively, aggressively and/or less predictably. Any of these variations may result in increased probability of conflict (Paikoff \& Brook-Gunn, 1991; Steinberg, 1987a). As teens are more emotionally labile and less able to deal with frustration, situations 
Parent-Adolescent Relations and Puberty

that in the past may have been normative conflicts between parent and child may become more intense and distressing battles.

Social Cognitive Model. Finally a social cognitive model of adolescent behavior includes consideration of parents' and adolescents' social skills and resources. Social cognition emphasizes developmental changes in the processes by which children and adolescents gather knowledge about their social world and the manner in which they process social information (Muuss, 1982; Youniss, 1975). Puberty is thought to be linked with the beginning stages of formal operational thinking and abstract reasoning (Inhelder \& Piaget, 1958) and thus the capacity to begin seeing the world in a more complex fashion. Teenagers' understanding of the social rules underlying relationships changes. Because parent-adolescent relationships are fertile ground for feedback, one of the first relationships early adolescents may began to question and test may be their relationship with their parents.

As they mature, adolescents shift their perception of the limits of parental authority (Smetana, 1988). Smetana found that adolescents, as they move through the fifth to twelfth grades, identify an increasing number of situations in which parental authority becomes less relevant. 
Parent-Adolescent Relations and Puberty

Typically teenagers regard individual preferences as increasingly important in such issues such as style of dress, sexuality and manners. Adolescents' parents, on the other hand, tended to see the same issues as involving social convention rather than personal choice.

As teenagers progress through puberty, they also come to expect and view as legitimate, increasing autonomy. This trend appears to be particularly relevant in terms of curfews, choice of dress and selection of friends (simmons \& Blyth, 1987). In work focused on parenting practices, Paikoff, Collins and Laursen (1986) found that as preadolescents move through the ages associated with puberty, they have increasingly less favorable responses to their parents power-assertive techniques.

Thus a social cognitive model would predict modulations in an adolescents outlook on life, perceptions of themselves and their rights and abilities as they move through puberty. However a social cognitive perspective does not necessarily include increased conflict. Disagreements between adolescents and their parents are more likely, but whether those disagreements result in intense confrontations would depend upon the flexibility and problem-solving skills of the parent and the adolescent as well as their history and patterns of conflict resolution. 
Many recent studies of parent-adolescent relations do not espouse a particular theory of adolescent development, but do assume that a fundamental emotional bond is maintained throughout adolescence in spite of the ebb and flow of parent-adolescent interactions. In these studies the focus is often on dysfunctional versus functional aspects of the relationship (e.g., Cooper, 1988; Cooper \& Ayers-Lopez, 1985; Hetherington \& Clingempeel, 1992; Youniss \& Smollar, 1985). Recent studies describe parent-child relations during puberty as a "realignment and redefinition of family ties" (Steinberg, 1990a). This involves renegotiation of limits and rules and a shift from unilateral authority to mutuality (Youniss \& Smollar, 1985) and a change from a primarily vertical relationship to a somewhat more horizontal relationship (Hartup, 1989). All major psychological theories of adolescent development predict decreasing emotional involvement and closeness between parents and their adolescents and an elevated risk for disagreements and conflict.

Review of Literature Focusing on Parent-Child Relations and Puberty

A number of researchers have focused on pubertal transitions in early adolescents to better understand changes in parent-adolescent relations. While there are 
many parenting behaviors that impact on their children, three primary dimensions of parenting behavior that have been studied are: (1) warmth and support, (2) conflict and negativity and (3) control (Maccoby \& Martin, 1983). A fourth dimension, monitoring, completes Maccoby and Martin's list. Unfortunately, because of measurement problems, monitoring was not included in this study. Several, not entirely consistent findings, have emerged from the research literature.

Warmth/Support. Increased emotional distance or a lower level of warmth and support across pubertal development has been reported by several researchers particularly for mothers and their adolescent offspring. This pattern has been found for mothers and their postpubertal sons by a number of researchers (Anderson, Hetherington \& Clingempeel, 1989; Papini et al., 1988; Papini \& Sebby, 1985; Savin-Williams \& Small, 1986; steinberg, 1987a) and has been reported for fathers and their late-pubertal sons as well (Steinberg, 1988). A similar pattern has been found for pubertal girls with physically mature girls (versus less mature girls) reporting less cohesion with their parents, feeling less acceptance from them, and feeling more emotionally autonomous from them (Steinberg, 1987a, 1988). 
Parent-Adolescent Relations and Puberty

It is not clear that the changes in parent-adolescent warmth across the pubertal development of the adolescent are simply a linear increase. Several researchers have reported curvilinear effects with emotional closeness increasing in late puberty or in post-pubertal phases. However the level of warmth does not always return to prepubertal levels (J.P. Hill, 1988; J.P. Hill et al, 1985a; Hunter \& Youniss, 1982; Mekos, 1991).

Conflict/Negativity. As assessed by a variety of methods and reporters, adolescents experience higher amounts of conflict with their parents when compared to prepubertal levels of conflict (Montemayot \& Hanson, 1985). Pubertal development appears to be related to this increase for both boys and girls (Hill, Holmbeck, Marlow, Green \& Lynch, 1985a, 1985b; Papini, Datan, \& McCluskey-Fawcett, 1988; Steinberg, 1977, 1981, 1987a; Steinberg \& Hill, 1978; Sussman, Inoff-Germain, Mottelmann, Cutler \& Chrousos, 1987). Several studies have found this relationship to have curvilinear components (Steinberg, 1988, 1981, Steinberg \& Hill, 1978), although the pattern appears to vary by family type (Anderson, Hetherington and Clingempeel, 1989). Mothers, in particular, appear to receive the brunt of pubertal-related conflict (Baumrind, 1991; Steinberg, 1987a). Researchers have noted that indicators of 
Parent-Adolescent Relations and Puberty

negativity in daughter-father relationship are few (Hill, 1988; Steinberg, 1987a; Armentrout \& Burger, 1978) as compared to mother-daughter relationships. Several reasons have been offered for this finding. First, mothers are an easier target for negative feedback given the traditional status and power of fathers (Steinberg, 1987a). Second, consistent with object relations theory, both sons and daughters have a greater need to individuate from mothers than from fathers (Blos, 1979; Chodorow, 1978). Bickering and arguing may reflect attempts at individuation. Third, most conflicts center around day-to-day activities and mothers are simply more likely to be around and actively involved in such activities (Montemayor, 1983, 1986). Finally father-adolescent and mother-adolescent relationships differ in emotional tone with fatheradolescent relations tending to be disengaged or affectively flat while mother-adolescent relations are more emotionally intense and volatile (Youniss \& Smollar, 1985).

Control. Across pubertal maturation, there appears to be a general pattern that perceived parental control decreases for both sons and daughters. While parental control decreases in a linear pattern for boys there is a slight curvilinear pattern for girls as well as an overall decrease for girls. Parental control in the form of 
Parent-Adolescent Relations and Puberty

yielding to parents in decision making has been found to decrease across pubertal development (Hill, 1988; Montemayor \& Hanson, 1985; Steinberg, 1981). Adolescent autonomy, a construct with a theoretically inverse relationship with parental control, has been found to increase across the pubertal development of adolescents (Steinberg, 1987a). Both boys and mothers report that parental permissiveness increases while parental authoritarianism decreases for boys with similar, but somewhat less clear trends for adolescent girls (Steinberg, 1987a). Control measured as interruptions by mothers of sons and by sons of their mothers yields a curvilinear pattern with increases during early pubertal development, but decreases later in the pubertal cycle (steinberg, 1981).

These patterns have been found to vary across family types. Anderson, Hetherington and Clingempeel (1989) examined this issue utilizing three families types: nondivorced families, stepfather families and single-parent mother-headed families. For mothers in nondivorced homes they found support for a general linear decrease in maternal control across pubertal development and within the overall linear decrease a curvilinear pattern as well. Fathers in these same homes perceived decreased control over their daughters as they physically matured, but reported a 
curvilinear relationship between self-rated paternal control and their sons' pubertal development. In stepfamilies perceived maternal control showed a linear decrease across the pubertal development of their daughters, but not their sons. Stepfathers' perception of control was curvilinearly related to pubertal growth for both sons and daughters, but only for one of the three waves of data collection. For divorced single-parent mothers, no relationship was found between maternal perceived control and pubertal maturation. Thus, in summary, it appears that pubertal maturation has an impact on the family system independent of changes attributable to the adolescent's chronological age (Steinberg, 1987a; Magnusson, Stattin \& Allen, 1985; Papini \& Sebby, 1987). However several researchers have pointed out that while pubertal development has an impact on the overall parent-child relationship, its impact appears to be relatively small (Paikoff and Brooks-Gunn, 1991; Hill, Holmbeck, et.al, 1985b). However small the effect may be, it has been found across diverse measures of pubertal status including global ratings of secondary sex characteristics from trained observers (Papini, Datan \& McCluskey-Fawcett, 1988; Steinberg, 1981; 1987a), radioimmunoassays of pubertal hormones from serum (Sussman et al., 1987) and from saliva (Steinberg, 1987b) and self-report measures of pubertal 
Parent-Adolescent Relations and Puberty

maturation (Hill et al, 1985a).

Timing of Puberty. Another important aspect of

adolescent development is the timing of puberty relative to one's peers (Hill, 1988; Steinberg \& Hill, 1978; Caspi, Lynam, Moffitt \& Silva, 1993; Paikoff \& Brooks-Gunn, 1991). Paikoff and Brooks-Gunn (1991) outline a number of interacting spheres that impact the experience of pubertal change: biological processes, cognitive processes, expectations and attributions of socially significant others and self-definitional changes. An early onset of puberty may upset development by taxing a teen's resources in one sphere to compensate for not-yet-developed skills in other arenas. For example, the early maturing girl may experience modified peer relationships because of reorganized friendships or because of moving into a new social network. These changes may be difficult to assimilate without the cognitive support of more mature definition of herself.

Adolescents' feelings about their perceived timing of puberty were investigated by Dubas, Graber \& Peterson (1991). They reported that boys regardless of pubertal timing felt more positive than girls regarding their physical development. In contrast, girls and in particular early maturing girls reported significantly lower positive feelings about their pubertal development. Peterson (1985) 
also reported that girls, especially early maturing girls, are more likely than boys to feel negatively about their pubertal changes.

For both males and females the majority of physical processes that comprise pubertal development are continuous (Paikoff and Brooks-Gunn, 1991). Distinct from males, females have one relatively discrete pubertal event, menarche, which roughly corresponds to the apex of pubertal development and offers a simplification of the measurement of pubertal development. Possibly because of this difference, the majority of pubertal timing research has focused on females.

Because of the generally more negative experience of girls and the availability of a discrete pubertal event, the role of timing on parent-child relationships for girls is of particular interest. More difficult and stormy parent-child relationships have been found by a number of researchers for early-maturing girls (Hill, 1988).

specifically less parental warmth/support or involvement were noted for early maturing girls in both mother-daughter and father-daughter relationships by Hill (1988). However, Savin-Williams and Small (1986) and Steinberg (1987a) reported in earlier studies that perceptions of support were unrelated to pubertal timing for 
Parent-Adolescent Relations and Puberty

both parental and child reports. Regarding parent-child negativity and timing of puberty, a number of researchers have consistently reported that early maturing girls reported more family friction and conflict (Peterson, 1985; Savin-Williams \& Small, 1986; Hill, Holmbeck, et.al, 1985b). A number of studies have reported early-maturing girls in contrast to on-time and later maturing girls as being more likely to engage in norm-breaking behavior and sexually precocious behavior, to have disrupted peer relationships, conduct problems in school and lower academic success (Simmons \& Blyth, 1987; Magnusson, Stattin \& Allen, 1985; Caspi \& Moffitt, 1991). These behavioral changes are likely to set the stage for increases in parent-child conflicts and disagreements. Caspi, Lynam, Moffitt and Silva (1993) found that the above behavioral changes were related to earlier externalizing behavior and exaggerated by association with delinquent peers.

Studies examining pubertal development as related to parental control in the form of nonadherence to parental advice and decision-making freedom were inconsistent (SavinWilliams \& Small, 1986). Decreases in parental control have been reported by early-maturing girls (Simmons, Blyth \& McKinney, 1983). These reported differences between early and on-time or late maturing girls disappear over time. 
Parent-Adolescent Relations and Puberty

Parents, at least those of a higher SES bracket, tend to perceive themselves as increasing attempts at control and restrictiveness with early maturing girls (Hill, Holmbeck, et.al., 1985b).

However, as has been pointed out above the interplay between family relations and puberty may be specific to family type. Effects on family relationships specific to pubertal timing have been found in single-mother homes (Hetherington, 1972, 1988). Mekos, Hetherington \& Clingempeel (1992) found that the timing of menarche for young adolescent females was earlier in stepfather families than in nondivorced families. Thus being in a home with a nonbiologically related male may somehow hasten the process of female puberty. Whatever processes creates a correlation between the presence of a nonbiologically related male and early female pubertal development may also have additional impacts on the familial relationships of early maturing girls in stepfamilies.

Steinberg (1987a) and Savin-Williams and Small (1986) have concluded from their review of the literature that in general, the effects of pubertal status on family relations are more consistent and striking than are those of pubertal timing relative to the adolescent's peers. Their explanation for this effect was that timing may be more 
Parent-Adolescent Relations and Puberty

relevant to social environments where early development versus late maturation has more salience (e.g., peer group) whereas within the family the absolute level of pubertal development may have more meaning. This may be accurate for the most commonly studied sample of white, middle class, nondivorced families. As pointed out by Paikoff and BrooksGunn (1991) consideration of minority groups, including various family types, are essential in understanding the role of pubertal development and pubertal timing in the ebb and flow of parent-adolescent interactions.

\section{Limitations of Literature}

As is common to much of modern psychological research, most of the research to date has relied primarily on adolescent samples from White, two-parent, intact, middleto-upper class homes and have often included samples of only one gender (Paikoff \& Brooks-Gunn, 1991). Only a few researchers have attempted to examine differences in the effects of pubertal development across various types of families (e.g., Anderson, Hetherington \& Clingempeel, 1989; Mekos, 1991). A history of parental divorce, a period of single parenthood or a remarriage may have substantial effects on the relationships between changes in parenting behavior and pubertal development (Anderson, Hetheringon \& Clingempeel, 1989; Mekos, 1991; Paikoff \& Brook-Gunn, 1991). 
Parent-Adolescent Relations and Puberty

Another frequent shortcoming is the practice of investigating the relationship between pubertal development and parenting behavior with cross-sectional data. Crosssectional data although useful, but may or may not produce the same patterns as longitudinal data. While there are notable exceptions, many studies attempt to extrapolate longitudinal parent-adolescent trends associated with puberty from cross-sectional data.

\section{The Focus and Hypotheses of This Project}

The relationship between pubertal development and parenting is often assumed to be linear. Typically the analyses utilized to assess those relationships are designed to test for linear relationships. This project was designed to directly test for curvilinear relationships within and between gender and family type groups. Because relationships between parenting behavior and pubertal development have been found to vary in mother-adolescent versus father-adolescent relations (e.g., Anderson, Hetherington \& Clingempeel, 1992; Mekos, 1991; Steinberg, 1988), the differences in the above relationships were examined separately for mothers and for fathers.

In addition to comparing family type, consideration is also given to an issue that has recently come to the attention of parent-adolescent researchers. Family type by 
Parent-Adolescent Relations and Puberty

itself does not highlight a potentially important aspect of parent-child relations. Henderson and Hetherington (1992) have shown that biological relatedness or ownness predicts significantly different qualities in intrafamilial

relationships. In intact families, ownness is a part of all parent-child relationships, but ownness may or may not be a part of a given parent-adolescent relationship within stepfamilies.

Exploratory analyses assessed ownness as part of a trichotomous family type variable: (1) biologically-related parent-adolescent dyads in nondivorced households, biologically- related parent-teen pairs in stepfamilies and (3) stepparent-stepadolescent relationships in stepfamilies. Due to the sampling criteria, there were too few stepmotheradolescent dyads for analysis. Thus for mother-adolescent dyads only nondivorced versus stepfamily comparisons were made. For father-adolescent dyads there were sufficient stepfather-adolescent pairs in the stepfamilies to compare ownness with other family types.

The major hypotheses of this study predicted a longitudinal curvilinear relationship between parenting behavior and pubertal development: (1) a positive quadratic relationship for parental positivity, that is, minimal positivity as the adolescent reaches the mid-point of 
Parent-Adolescent Relations and Puberty

pubertal development and (2) a negative quadratic relationship for negativity and control, i.e., negativity and control increase up to the point of mid-puberty and then decrease during the later phases of pubertal growth.

Support for these curvilinear relationships was assessed via multivariate analyses and in post hoc univariate comparisons that will be detailed later.

Additional hypotheses predicted across-time trends, family type differences, differences related to adolescent gender, varying patterns in biologically versus nonbiological related parent-adolescent dyads and differences based on the timing of pubertal development for girls. Because of the number of analyses and the number of dependent variables, these hypotheses were examined only if significant multivariate findings were evident. When significant multivariate results were found the following differences were expected: (1) across-time decreases in postivity and control and increases for negativity, adolescents in stepfamilies would endure more negativity and experience less parental positivity and control then those in nondivorced homes, (3) more findings were expected for father-daughter and mother-son relationships than for father-son and mother-son relationships, (4) stepparentstepadolescent relationships were expected to show more 
extreme and divergent patterns than biologically related parent-adolescent dyads, (5) girls who began pubertal maturation earlier than their peers were expected to experience more parental negativity and less parent positivity and control then their on-time and late maturing counterparts.

\section{Method}

Sample

The data for this project were selected measures and subscales from the Nonshared Environment of Adolescents Study--Wave 1 (NEAD-1) and Wave 2 (NEAD-2) conducted by David Reiss at George Washington University, Mavis Hetherington at University of Virginia and Robert Plomin at Pennsylvania State University. The first wave of data was collected in 1988 and early 1989 and the second wave was collected in early 1992 .

The sample was obtained from 47 of the 48 contiguous states through random digit dialing and from two market panel surveys. Ten thousand households were screened through random digit dialing which resulted in finding 210 eligible families who agreed to participate. Because of the cost of random digit dialing and the difficulty of finding the particular family types desired, the remainder of the families were obtained from a pool of 30,000 potentially 
eligible households in the market panel pool. Families were selected on the basis of having a mother and father living in the home and at least two same-sex children between ages 10 and 18 with no more than 4 years difference between the ages of the two target siblings. Parents in stepfamilies were required to have been married for at least five years. A total of 719 families were interviewed and included in the sample at Wave 1 .

The sample for Time 2 (approximately two and one-half years later) was all of the families assessed at Time 1 who still had both of the target siblings living in the household the majority of an average month. Approximately 400 families fit the criteria for inclusion and agreed to participate in a second wave of data collection.

For the purposes of this study only the data for the younger child (Child 2) in the families interviewed at both waves are included. Child 2 was selected to provide the greatest range in pubertal development across the two waves of data collection. Subject, parental and family characteristics for the 398 families in this sample are displayed in Table 1 .

Insert Table 1 about here 
At Wave 1 the age of Child 2 ranged from 10 to 18 with a mean age of $12.2(S d=1.9)$ years. The time between Wave 1 and Wave 2 averaged 2.6 (males) and 2.5 (females) years. Fifty-one percent of the sample were males and $49 \%$ were females. Parents' ages averaged 37.7 years for mothers and 40.4 years for fathers. Parents had been married an average of 18 years within intact families and nine years within stepfamilies. Virtually all of the fathers and the vast majority of mothers were employed outside the home. The average Hollingshead SES ratings placed the majority of the sample families at the level of mid-level business personnel, minor professionals and technical workers. Most of the sample families had more children than the two children participating in the larger study. Fifty-one percent of the families in this project were nondivorced families and $49 \%$ were stepfamilies. Twenty-nine percent of the fathers were stepfathers (approximately half with stepsons and half with stepdaughters). The vast majority of mothers (94\%) were biologically related to Child 2 although about half of the mothers were in stepfather families. Most of the stepfamilies consisted of stepfather families although the target child was not always the stepchild. Fifty-nine percent of the stepfathers $(29 \%$ of the total sample of fathers) were not biologically related to Child 2 . 
Parent-Adolescent Relations and Puberty

\section{Procedures}

At Time 1 and Time 2 potential sample families were contacted by trained telephone interviewers who discussed with one of the parents the purposes of the NEAD study, confirmed sample inclusion, and if the family agreed to participate, arranged for interviewers to visit their home twice. During each visit parents and adolescents completed a large set of questionnaires and between visits they finished a take-home package of questionnaires. Professional interviewers trained by project staff at George Washington University and University of Virginia visited each home and administered observational procedures to both parents and the two target adolescents. The questionnaire measures assessed the adjustment of the parents and adolescents, the marital relationship, parent-adolescent relationship and sibling relationships. In addition, demographic information and data regarding extrafamilial relationships, and stressful life events were gathered.

The observational procedure involved "hot problem" solving sessions. Eäch dyadic combination of the two parents and two adolescents were instructed to discuss and attempt to reach a solution to an on-going conflict that both members of the dyad had agreed was an issue. A tetradic session involving all four family members was also 
recorded. These 10-minute problem-solving sessions and independently rated by trained observers. Each observer received approximately 100 hours of training ranging from group meetings with feedback to independent practice codings. All observers reached an overall exact agreement rate of $60 \%$ with the criterion rater in $85 \%$ of the codes (or more) by the end of training. An average of $40 \%$ of each observer's data was utilized in reliability estimates. Coders who fell below $60 \%$ overall exact agreement were retrained until they regained appropriate reliabilities. Their data (back to the most recent maintenance reliability check) was recoded by another coder who was meeting criteria. Reliabilities for each parenting behavior are discussed later and reported in Table 12-14. Satisfactory reliabilities were obtained for all measures used in this study .

\section{Measures}

While a large number of measures were collected from the original NEAD sample, only the measures used in this paper will be described in the following sections. Table 2 summaries the measures utilized and the reporters for each measure. 
Parent-Adolescent Relations and Puberty

Insert Table 2 about here

\section{Adolescent Measures.}

Puberty. Pubertal development was assessed through parent ratings and adolescent self-reports based the Pubertal Development Scale (PDS). The PDS is a measure of pubertal status with a version for boys and for girls (Petersen, Crockett, Richards \& Boxer, 1988). The measure gathers ratings on a number of physical variables relevant to puberty and pubertal stage ratings are derived from those ratings. For boys the PDS focuses on the development of adult patterns of body hair, voice changes and facial hair growth. For girls, the PDS centers on body hair development, breast development and the presence or absence of menarche. Each item, except menarche, is responded to on a 4-point response scale ranging from "has not begun" to "is completed".

Because the sample was marginally adequate for the number of cells required in the data analyses, some conservative data clean-up was completed on the pubertal items. Substitute values were computed for seven cases which were missing only one variable out of the 12 PDS ratings ( 3 adolescent ratings and 3 mother ratings for each 
Parent-Adolescent Relations and Puberty

wave). These substitutions for missing ratings were completed only in cases in which at least four out of six of the adolescent's and mother's remaining ratings had $100 \%$ exact agreement. The substitute value was the corresponding rating from the other respondent. Cases with more than one missing value were not cleaned.

In a number of cases a respondent gave inconsistent ratings from Wave 1 to Wave 2 , e.g., a breast development rating of ' 3 ' at Wave 1 and a rating of ' 2 ' at Wave 2 . Clean-up for inconsistent ratings occurred on the basis of 3 criteria: (1) only one set of the Wave-1-to-Wave-2 ratings from both raters was inconsistent (three ratings over two waves), (2) the discrepancy between the ratings was no greater than one value and (3) at least four out of six of the adolescent's and mother's remaining ratings showed $100 \%$ agreement. Ratings for seventeen girls, 19 boys and six mothers fit these criteria. These cases were nearly equally split between nondivorced and stepfamilies and were distributed across pubertal stages. Given this pattern it is unlikely that the cleaning biased the results of the analyses (Tabachnick \& Fidell, 1989).

These across-time inconsistencies were modified to indicate no change in that particular rating and the value closest to the mean value across all ratings was utilized. 
For example, if an adolescent rated himself on body hair development as a ' 3 ' at Wave 1 and $a$ ' 2 ' at Wave 2 and the average of all 12 pubertal ratings (across mother's and adolescent's data) was 2.3 , the '3' at Wave 1 was changed to a '2'. If there was more than one across-wave inconsistency across the six ratings or if the difference between the inconsistent ratings was two or greater, the case was not cleaned.

Cronbach alphas from the Petersen et al. (1988) study ranged from .68 to $.78(\mathrm{MD}=.73)$ for boys and .76 to .83 $(\mathrm{MD}=.78)$ for girls in the 6 th through 8 th grade. BrooksGunn et. al., (1987) found respectable convergent validity of the PDS using a sample of $15111-, 12-$, and 13-year olds. Significant correlations between the self-rated PDS scores and physicians' Tanner ratings of pubertal development ranged from .67 for the pubertal status score to .61 for breast development and .62 for body hair growth. The average cronbach alphas across age groups was .70 .

Cronbach alphas and interitem-total correlations from the PDS for this sample are displayed in Table 3 . Cronbach alphas for the female sample range across waves and across mother and daughter ratings range from .72 to .91 with a mean of 82 . Cronbach alphas for the male sample ranged from .78 to .91 with a mean of 86 . These values are slightly 
Parent-Adolescent Relations and Puberty

higher than those reported by Peterson et.al (1988).

Insert Table 3 about here

In Table 4 estimates of inter-rater reliability and agreement for each item and the overall PDS score are presented in the following forms: (1) percent exact agreement, (2) percent agreement within one value (e.g., agreement is counted if a daughter rates herself as ' 2 ' and a mother rates her daughter as '1'), (3) Spearman's correlations and (4) weighted kappas. Weighted kappas correct for chance agreement and are weighted by the magnitude of disagreement.

For girls percent exact agreement across the PDS items averaged $77 \%$ at wave 1 and $77 \%$ at wave 2 ; percent agreement within one, excluding menarche, averaged $96 \%$ at wave 1 and $98 \%$ at wave 2 ; correlations were significant at both waves and averaged .77 and .63 ; weight kappas averaged .77 at wave 1 and .66 at wave 2 (kappa statistic was not used for menstruation). These same statistics for the PDS stage scores were similar or higher than the item level values. Boys and mothers agreed somewhat less than did the girls regarding their pubertal status. Percent exact agreement across the PDS items averaged 59\% at wave 1 and 
Parent-Adolescent Relations and Puberty

$52 \%$ at wave 2 ; percent agreement within one averaged $92 \%$ at wave 1 and $95 \%$ at wave 2 ; correlations were significant at both waves, averaged .63 at both waves; and weighted kappas average .48 at wave 1 and at wave 2 . While the percent exact agreement is somewhat lower than the females, the correlations are significant and the weighted kappas reflect acceptable reliabilities.

Insert Table 4 about here

For the current study, Peterson's (1988) scoring algorithm was utilized to compute stage scores of pubertal development. Peterson's scoring is designed to approximate the five Tanner stages of pubertal development: pre-puberty, early puberty, middle puberty, advanced puberty and postpuberty. For each adolescent three pubertal stage scores were computed. One based on the adolescents' selfratings of their own development, a second representing mothers' perceptions of their daughter's or son's development and a third score that combined ratings from both the adolescent and his or her mother. For the combined scores cutoffs defining the stage scores were derived to approximate the average Tanner five-stage frequency distribution between the adolescents' and mothers' ratings. 
Table 5 displays the number of children and average age of each child classified into each pubertal stage by the combined pubertal rating, the adolescent's ratings of their own pubertal development and their mother's ratings of their pubertal growth. As can be seen in Table 5 age trends follow the expected patterns of increasing mean age with pubertal development.

Insert Table 5 about here

Continuous measures of pubertal growth. The major focus of this project was to assess curvilinear trends. Ideally one would have numerous assessments of pubertal growth enabling the computation of longitudinal growth curves. Such data is not available in this project. One method of approximating longitudinal patterns is to segment the hypothesized curvilinear pattern into pubertal growth groups that represent major portions of the curve and then test for mean differences between the groups.

Three pubertal growth categories were derived based on pubertal stage scores from Wave 1 to Wave 2: no change, early-to-mid puberty and mid-to-late puberty. The No Change group were those adolescents who did not substantially change in pubertal growth over the two waves. The Early-to- 
Parent-Adolescent Relations and Puberty

Mid group included adolescents whose pubertal development was before the midpoint of puberty. The Mid-to-Late group was for teenagers who were at least at the mid-point of puberty by Wave 1 and continued to mature. The No Change category provides a comparison group against which the other two pubertal growth categories can be compared. Figure 1 represents the scoring pattern utilized to derive the pubertal growth categories.

The small group of individuals who were rated as stage 2 (early puberty) at Wave 1 and stage 4 (advanced puberty) at Wave 2 provided a challenge in determining which pubertal growth group they most appropriate fit. These cases were individually examined and categorized based on the ratings. For example individuals who were in the beginning stages of early puberty and grew into the early stages of advanced puberty were categorized as early-to-mid pubertal developers. Those moving from late stage two into late stage four were classified as mid-to-late developers. Table 6 shows the percentage of adolescents grouped into each pubertal growth category for each type of pubertal rating: the combined ratings and the ratings by adolescents and by mothers. 


\section{Insert Figure 1 and Table 6 about here}

Additional exploratory analyses were designed to assess whether the relation between a variable representing curvilinear pubertal growth and changes in parenting behavior was significantly different across the various child gender by family type/ownness groups. As pubertal development is a gradual process, a second pubertal growth variable was constructed. This variable was continuous a representation of curvilinear pubertal change. It was computed by employing summary scores from the pubertal growth ratings. This variable (continuous, curvilinear pubertal growth or CCPG) provided a represention of a negative quadratic patterns with the apex of the curve at the midpoint of pubertal development. Thus a significant relationship between CCPG and a parenting behavior variable would indicate a negative quadratic curvilinear relationship between the parenting behavior and pubertal development.

In the computation of the CCPG, the summed scores of the pubertal ratings from Wave 1 and Wave 2 were utilized so that no change was represented by zero, positive scores indicated change from early puberty up to the mid-point of pubertal growth and negative scores demonstrated pubertal 
Parent-Adolescent Relations and Puberty

change beyond the mid-point toward late puberty. Within gender the midpoint was anchored to the 50 th percentile scores of adolescents classified as mid-pubertal at wave 1 . Because of the difficulties of combining dichotomous and continuous data, the menarche item was dropped for the girls in constructing the CCGP.

of course, there were a number of individuals whose pubertal growth occurred on both sides of the mid-point. Those with equal amounts of growth up to the mid-point and beyond the mid-point were coded as zero. Those who moved over the mid-point and had more post-midpoint growth than pre-midpoint growth received a score slightly below zero. Those with more early-to-mid pubertal growth than mid-tolate pubertal growth scored a corresponding amount above zero. The more change that occurred away from (or towards the mid-point), the lower (or higher) the obtained CCPG score.

The CCPG variable was utilized to examine the strength of a curvilinear relationship between pubertal growth and changes in parenting behavior. Because the sample need not be divided into pubertal growth categories, exploratory analyses were utilized to scrutinize differences in the strength of the relationship between pubertal growth and parenting by gender and family type/ownness groups. A test 
Parent-Adolescent Relations and Puberty

for homogeneity of regression line was utilized to find significant differences between the regression line of each family type by gender group and the average regression line of the sample.

An additional advantage of this variable over traditional pubertal growth variables, such as pubertal stages, is that CCPG is less correlated with age. For girls the average correlation between CCPG and age is -0.40 while the average correlation between the three pubertal stage ratings and age is 0.72 (the correlation between age and CCPG is negative because the CCPG was designed to represent a negative quadratic relationship). For boys the same average correlations are less distinctly different, 0.55 and -0.69 respectively. This decrease in overlapping variance between age and measures of pubertal development allows for a somewhat cleaner assessment of the relationship between pubertal change and parenting behavior with less age effect.

Table 7 shows the mean CCPG, standard deviations and cell sizes for girls and boys. The means for the pubertal change groups exhibited the expected patterns: high positive scores for the early-to-mid pubertal change group and low negative scores for the mid-to-late pubertal change group. The no change group yielded average scores with small negative values as there were often small increases in 
individual ratings that were not sufficient to change the pubertal stage value. Because the a majority of adolescents, particularly the girls, in the No-Change group were rated as mid-pubertal or advanced pubertal, what change did occur was post-mid-puberty.

Insert Table 7 about here

Timing of puberty. A portion of the analyses focused on the timing of puberty for the females. No items reflecting the timing of puberty for boys was available. Both mothers and daughters reported on the month and year that the daughter began menstruating. Table 8 shows the ages (mean, standard deviation, lowest and highest) of the girls' age at menarche. The mean age for daughters', mothers' and combined reports are very similar. The mean age at menarche for this sample is 12 -years 6-months. This matches precisely the average age of menarche reported by Paikoff and Brook-Gunn (1991) for a large sample of U.S. girls.

Insert Table 8 about here

Because of the large number of missing variables for 
month or year across the two waves and two reporters, age at menarche was computed in a stepwise fashion. The first step was to examine the data of those mother-daughter dyads who agreed at both waves that menstruation had begun by Wave 1 . The average reported age of menarche was then computed for those mother-daughter dyads who agreed that menstruation had begun by Wave 1 and whose reports were within a 6 -months time period $(n=36)$. Second, there were a group of girls who according to both mothers and daughter had began menstruation by the first wave but part of the timing information was missing. If the year/month data was missing for one respondent and available for the second, the second respondent's data was utilized to estimate age at menarche. This resulted in an additional 20 values. Third, for mother-daughter pairs who agreed that menarche had not occurred by Wave 1 , but agreed (within 6 -months) that it had occurred by Wave 2 , their estimates were averaged. This yielded an additional 33 scores. Fourth, for those daughters who according to both mother and daughter had began menstruation between Wave 1 and Wave 2 , if reports from one respondent were missing and available for the second respondent, the available data was utilized as outlined above producing an additional 23 values. Fifth, any remaining cases in which either the daughter or the 
Parent-Adolescent Relations and Puberty

mother reported on menarche at both Wave 1 and Wave 2 and at both waves the pubertal timing items were within 6 -months of each other, the average of those Wave 1 and Wave 2 reports were utilized. Sixth, an examination of the remaining cases found a few additional cases for which an estimate could reasonably be calculated. For example, across the four reports of year and month of menarche (two waves and two respondents), three reports for year agreed, but only one of the four potential reports of month of menarche were available. These six steps yielded estimates of age at menarche for a total of 121 of the girls.

Assignment to groups representing timing of puberty were based on the 25 th and 75 th percentiles of the total pubertal timing sample similar to methods used by Caspi, Lynam, et.al, (1993), Simmons and Blyth (1987), Gargiulo, Attie, Brooks-Gunn and Warren (1987) and Brooks-Gunn, Attie, Burrow, Rosso and Warren (1989). This resulted in girls with menarche beginning at less age 11 years 11 months categorized as early developers; girls with menarche beginning between ages 12 years 0 months and 13 years 3 months codified as on-time maturers and girls with menarche beginning after age 13 years 3 months as late maturers. These age categorizations are similar to those utilized by Mekos (1991), are approximately 3-6 months earlier than the 
Parent-Adolescent Relations and Puberty

cutoffs used by Capsi, Lynam et.al, (1993). Table 9 displays the average age at menarche for the three pubertal timing groups, the range of ages and the number of girls in each category.

Insert Table 9 about here

Previous research (Mekos, Hetherington, Clingempeel \& Reiss, 1992) found the following inter-rater reliabilities and concordances for mothers' and daughters' ratings of timing of menarche: year of onset, $67 \%$ exact agree; agreement within six months, $69 \%$; and a correlation of .71 for age of menarche. Hill (1988) found agreement of $80 \%$ for mothers' and their seventh-grade daughters' reports of menarche across six-month segments of time. Correlations for these reports ranged from .87 to .91 . Dubas, Graber and Peterson (1991) reported that approximately one half of their sample of teens assessed across three years were consistent in self-ratings of pubertal timing relative to peers.

In Table 10 the interrater and across-time concordances (agreement with six months and correlations) for the current sample are displayed. Interrater agreement (within six months) was in the same range as the Mekos et.al (1992) 
Parent-Adolescent Relations and Puberty

study and the correlations between raters were higher. It is interesting to note that the across-time agreements are substantially lower than across- reporter, within-wave agreements. Given the amount of missing data and the lower agreement across wave, one may wonder if the format of asking respondents for the specific month and year that menarche began is difficult for many subjects.

Insert Table 10 about here

Measurement of Composite Parenting Variables

Multi-respondent, multi-method measures of each parent's behavior toward their adolescent were computed by combining data from each of the father, mother and adolescent data and from the observer's ratings. Through questionnaires, each subject described their perception of each parent's behavior, i.e., adolescents reported on each parents' behavior toward themselves, each parent described their own conduct toward the target child and each parent reported on their partner's parenting actions toward their teenager.

Factor analyses conducted at the University of Virginia and at George Washington University confirmed the existence of a positivity, negativity and monitoring/control factor. 
Parent-Adolescent Relations and Puberty

The composition of the parenting factors is based on the factor loadings obtained from those analyses. For theoretical reasons and because of limitations of the monitoring measures the control/monitoring factor was limited to parental control. All of the variables comprising the parenting composites were scored and cleaned at Penn State University.

Because of the number of scores integrated into the composites, all of the questionnaire scales scores and observational measures were converted in z-scores based on the overall mean and standard deviations for wave 1 data. The overall means were computed by combining data from the male and female adolescents, but were computed separately for mothers' and fathers' data because none of the analyses directly compared mothers' and fathers' behavior. This allows for direct comparisons across waves and across genders of the adolescent. As noted above, three parallel sets of variables were computed for each parenting composite: a combined score consisting of the average score of the adolescent and the parent, a variable representing the teenager's perspective and the mothers attitude. No analyses focused on the father's perspective because pubertal development ratings from the father were not collected. Thus analyses relating fathers' perspective of 
parenting behaviors to the fathers' ratings of pubertal development could not be completed.

Internal reliability estimates for each of the three sets of composite measures is presented in Table 11. Cronbach alphas are displayed for the multi-respondent (or combined) composites, mothers' reports based on a number of measures, and the adolescents' report gleaned from several questionnaires. Following are details regarding the variables utilized to create the composite scores.

Insert Table 11 about here

Parental Positivity. Adolescents', mothers' and fathers' perceptions of parental warmth and positive interactions were derived from their responses to the Closeness and Rapport subscale (CLRAP) of the Parent-Child Relationship Inventory, to the Expression of Affection Scale (EXAFF) and Instrumental Affection Scale (INAFF). Observer ratings of parental warmth were ratings of parental warmth/support, assertiveness, involvement and communication. For all of the scales utilized in deriving the parental warmth/support composite interobserver reliability and agreement (observational measures) as well as cronbach alphas (questionnaire measures) for Wave 1 and 
Parent-Adolescent Relations and Puberty

Wave 2 are presented in Table 12.

Insert Table 12 about here

The CLRAP questionnaire was taken from Hetherington and Clingempeel (1992) work which was based on measures from the zill and Furstenberg's National Survey of Children (zill \& Furstenberg, 1981). The CLRAP retained most of items from the Hetherington and Clingempeels' scale with a few modifications and the addition of several items assessing degree of similarity, understanding and caring about what the other party thinks of self. The final scale was intended to assess perceived warmth, quality of communication and involvement plus the additional qualities listed above. Cronbach alphas for mother and father report across three waves on the Hetherington and Clingempeel instrument ranged from .76 to $.90(M=.84)$ with two-month test-retest reliabilities ranging from .87 to .91 .

The EXAFF and the INAFF are second generation modifications of a scale used originally by Patterson (1982) in his research with coercive and antisocial children and their parents. Hetherington and Clingempeel (1992) utilized his scale to create 19 item seven-point response scale ranging from "more than once a day" to "not at all in the 
Parent-Adolescent Relations and Puberty

past month" regarding the frequency of joint activities of the adolescent and parent. Factor analytic work with this scale identified an expressive affection subscale (e.g., how often the parent hugged, spent time with, talked or joked with the adolescent) and an instrumental affection subscale (e.g., various joint activities engaged in by both). Cronbach alphas for the two scales ranged from .75 to .86 $(M=.82)$ for the former across three waves of data collection and .62 to $.80(M=.72)$ for the later across three waves. Test-retest reliabilities over two months time period for parents ranged from .78 to .87 for EXAFF and .76 to .83 for INAFF .

For all three of the above instruments, the CLRAP, EXAFF and INAFF, a child version was developed for the current project. The child form paralleled the parental questionnaire and was intended to obtain the child's perception of their mother's and father's warmth, closeness, expression of affection, etc.

Parental Negativity. Parental negativity was derived by taking the mean of several standardized scores from questionnaire measures of parent-to-adolescent conflict/negativity and observer ratings of parent negative behavior toward the target adolescent. The questionnaire measures gathered adolescents' perceptions of their parents' 
Parent-Adolescent Relations and Puberty

behavior and parents' perception of their own behavior: Parent-Child Relationship Inventory (Conflict subscale), Conflict Tactics Questionnaire (symbolic aggression subscale), Child Rearing Issues I (Total Conflict subscale), Child Rearing Issues II (Punitiveness subscale and Negative Sanctions subscale). Observer ratings of parental negativity and conflict were represented by the mean score on ratings of parental coercion, transactional conflict and anger/rejection. Interobserver correlations, agreement for the observational measures and cronbach alphas for the questionnaire measures is presented in Table 13.

Insert Table 13 about here

Items for the Parent-Child Relationship Inventory were originally derived from zill's (1981) work and were utilized by Hetherington and Clingempeel (1992) to create the ParentChild Relationship Inventory. For this project the instrument was modified by including a subscale intended to assess conflict. Items were added to assess ones' perception of how much the other party yells, nags, criticizes and gets into fights with the respondent. The response scale is a five-point scale ranging from "Extremely" to "Not at all". 
The Conflict Tactics Scale is Straus' (1979) measure modified by Fredman and Sherman (1987) to include childrens' reports of each other's behavior, childrens' reports of their parents' behavior toward them and parents report of their own behavior toward their children. For the current project the wording was modified slightly to fit the relationships in the families being assessed. The response scale was modified from a seven-point scale to a five-point scale. Answers ranged from "Not at all common or typical" to "Very common or typical". Only the symbolic Aggression subscale is utilized in this composite variable. Example items include "insulted the other", "stomped out", "did something to spite the other", "threatened to hit", etc.

A factor analysis of the items in this instrument resulted in factors similar to the ones reported by straus (1979). A factor analysis of the items utilized in this project and their Cronbach alphas are consistent with those reported by straus (1979). The Cronbach alphas for the Symbolic Aggression subscale for this sample range from .72 to .85 with a mean of .77 .

Child Rearing Issues I and II are adapted from Hetherington and Clingempeel's (1992) work. This 37-item measure assesses parent and child agreement on rules and disciplinary practices. The Total Conflict subscale derives 
from the total number of issues over which the teenager and parent have high-frequency conflict., The Punitiveness and Negative Sanctions subscales are obtained from items rating the parents discipline practices and reflects the frequency of use of harsh discipline practices and discipline centering on negative means of attempting to gain control. Cronbach alphas from Hetherington and Clingempeel's (1992) work for conflict items ranged from .58 to .91 ( $\mathrm{M}=$ $.77)$ and .64 to $.88(M=.79)$ for the discipline items (includes Negative Sanctions and Punitiveness).

Parental Control. Indicators of parental control were obtained from responses to the Child Monitoring and Control (CMC) and from observer ratings. The CMC contains three subscales: parental knowledge, parental attempted control and parental actual control. Adolescents, mothers and fathers all completed the instrument. The CMC is a modification of the Assessment of Child Monitoring and Control questionnaire utilized by Hetherington and Clingempeel (1992). Their version was based on parental authority/directiveness dimension of Baumrind's (1978, 1979) parent behavior Q-sort work.

Rather than using a Q-sort format, items were converted into 5-point rating scales assessing several domains of the child's behavior such as knowledge of who the child's 
Parent-Adolescent Relations and Puberty

friends were, how and what the child was doing in school, the child's interests and knowledge of child's engaging in a variety of deviant behavior.

The Hetherington and Clingempeel version had reported Cronbach alphas across three waves ranging from .47 to .90 $(M=.76)$ for the control subscales. Two month test-retest reliabilities ranged from .70 to .77 for the control subscales.

Observers rated each parent on their degree of parental influence and authority/control. Observer ratings of parental influence and authority/control were included in the parental control composite variable. Interobserver correlations, agreement for the observational measures and cronbach alphas for Parental Control in Table 14.

Insert Table 14 about here

\section{Data Analyses}

Assessment of Curvilinear Relationships. The first set of analyses were designed to assess curvilinear relationships between across-time changes in parenting and pubertal development by relating differences in parenting between Wave 1 and Wave 2 to pubertal growth. The difference (Wave 2 score minus Wave 1 score) between the z-score values 
Parent-Adolescent Relations and Puberty

quantified longitudinal changes in parenting. The pattern of difference scores between the pubertal change groups is the best estimate of within subject, longitudinal changes given two waves of data. Main effects related to pubertal growth group or to interactions which include pubertal growth are indicative of significant across-time changes in parenting that are related to the pubertal maturation.

For example, Figure 2 illustrates the expected patterns for a positive curvilinear relationship between changes parenting behavior and the three pubertal growth groups. The No-Change group is displayed as having scores near zero indicating inconsequential changes in parenting behavior from Wave 1 to Wave 2. The Early-to-Mid pubertal change group is shown with a positive change score manifesting an decrease in the parenting behavior from Wave 1 to Wave 2 . The Mid-to-Late pubertal change group is portrayed with a negative score indicating that parenting behavior increased from Wave 1 to Wave 2 . If an analysis detected a significant main effect for pubertal growth group and planned comparisons indicated that the Early-to-Mid pubertal growth group had greater change scores than the No Change group and that there was no significant difference between the No Change group and the Mid-to-Late growth group, the results can be interpreted as demonstrating a curvilinear 
Parent-Adolescent Relations and Puberty

relationship.

Insert Figure 2 about here

Cross-sectional patterns and relationships between absolute levels of parenting behavior and pubertal change involved the use of the original $z$-scores in repeatedmeasures MANOVAs. This allowed for a direct test of acrosstime trends via wave effects as well as testing for crosssectional mean differences in the absolute levels of parenting behavior as related to child gender or pubertal group groups.

Repeated measures analyses are often associated with the assessment of longitudinal patterns. However in this case significant pubertal growth group differences are not indicative of the amount of change in parenting behavior related to an adolescent's individual pubertal development. Rather, differences between pubertal growth groups highlight, for example, dissimilarities in the absolute levels of parents' behavior averaged across waves between adolescents who are not changing in pubertal status and those who are in the process of pubertal change. In this case the appropriate interpretation is that parents of adolescents who do not change in pubertal status are more 
Parent-Adolescent Relations and Puberty

likely than parents of adolescents who do change to exhibit higher levels of the behavior. Interactions involving wave effects potentially indicate differing patterns of longitudinal change, but such an interpretation can be very difficult or indicate significate differences in absolute level by wave. Thus the analyses of change scores were relied upon for assessment of longitudinal patterns. Pubertal timing was examined only across family type groups. Unfortunately the small sample prohibited simultaneous examination of both family type and pubertal growth group. As outlined above both difference scores and z-scores were analyzed. In this case change scores highlight differences in the amount of change in parenting behavior from Wave 1 to Wave 2 that the adolescent experienced while the repeated measures design examined the absolute level of the parenting behavior.

Exploratory analyses were conducted to examine differences between stepparent-child relationships and biological parent-child relationships in the association between pubertal growth and parenting behavior. First there were sufficient stepfathers to attempt multivariate analyses using three family types: nondivorced, parent-adolescent dyads within stepfamilies (biologically related) and stepparent-adolescent relationships. These results must be 
Parent-Adolescent Relations and Puberty

examined with caution as cell sizes varied tremendously with the smailest cells being under 10 subjects. Consequently the assumptions of multivariate analyses were not met. However given the newness of 'ownness' as an important family variable, these results are offered as suggestions for future research.

All analyses were conducted using SPSS/PC+ software. The difference score analyses and the repeated-measures analyses for both fathers' and mothers' parenting were $2 \times 2$ X 3 MANOVA designs, i.e., two gender groups, two family type groups and three pubertal growth groups. MANOVA analyses were utilized because of the increased possibility of Type I errors due to repeated testing of correlated dependent variables. A Bonferroni-type adjustment was made to create more stringent alpha levels for univariate effects. When the multivariate results suggested a univariate finding, univariate planned comparisons were run to examine gender and family type differences. In the case of pubertal growth group, post hoc comparisons were made whether or not the multivariate findings indicated a difference. However in no case were pubertal growth group differences found independent of the multivariate results.

Because of unequal sample sizes in the cells, unique sums of squares were used in all analyses. Based on the 
Parent-Adolescent Relations and Puberty

recommendations of Tabachnick and Fidell (1989), assumptions of MANOVA analyses were assessed via the Box-M statistic (homogeneity of variance), the determinant of the within cell correlation matrix (multicollinearity and singularity) and examination of scatterplots (linearity of relationships among dependent variables). The significance of the multivariate analyses were assessed using Pillai's criterion because of unequal cell sizes and increased possibility of heterogeneity of variance-covariance matrices (Tabachnick \& Fidell, 1989).

A second set of exploratory analyses involved testing for significant differences across the gender by family type groups in the strength or direction of the correlation between pubertal growth and parenting. The continuous measure of pubertal growth, CCPG, was utilized in testing for significant differences in regression slope between the gender by family type and ownness cells via the homogeneity of regression test in analysis of covariance. A significant regression between CCPG and a composite parenting variable indicated a curvilinear pattern. In these analyses it was possible to compute a regression line for the small cells, e.g., stepmothers with stepchildren. Thus family type and ownness comparisons were included for both mothers and fathers. For mothers in particular, the results should be 
Parent-Adolescent Relations and Puberty

viewed as tentative at best. For cases in which a significant difference via the omnibus covariance test was found, additional tests were completed in an attempt to identify which gender/family type/ownness groups were implicated in the significant relationship.

\section{RESULTS}

\section{Multi-Respondent Composites}

\section{Difference Score Analyses}

Mothers' Parenting. Few significant results emerged from the difference score analyses of multi-respondent composite ratings. The multivariate results highlighted significant differences for pubertal growth group for negativity and for family type (positivity). Univariate comparisons found that for negativity the Early-to-Mid pubertal growth group had consistently larger change scores than did the No Change pubertal growth group. There were no significant differences between the No Change and the Midto-Late group. Thus there was evidence of a negative curvilinear relationship between pubertal growth and mother's negativity. That is, there is a significant increase in maternal negativity that corresponded to their adolescents' early pubertal maturation.

The family type effects for positivity indicated that adolescents in stepfamilies experienced greater decreases in 
Parent-Adolescent Relations and Puberty

positivity than did teenagers in nondivorced families. Thus adolescents in stepfamily experienced greater decreases in maternal positivity than did teenagers in nondivorced families.

Although the multivariate result was not significant, a significant univariate finding suggested a relationship between maternal control behavior and pubertal growth by family type. During early pubertal growth, adolescents in stepfamily homes encounter greater decreases in maternal control than do adolescents in nondivorced homes.

The means and standard deviations for difference scores are presented in Table 15 and the multivariate and univariate findings are displayed in Table 16.

Insert Table 15 and 16 about here

Fathers' Parenting. No significant results emerged from the difference score analyses of multi-respondent composite ratings. There was no evidence supporting general patterns of curvilinear relationships between pubertal growth and fathers' parenting behavior. It appeared that in terms of across-time change scores for positivity, negativity and control, father-adolescent relationships are less extreme than are mother-adolescent relationships. The means and 
Parent-Adolescent Relations and Puberty

standard deviations are shown in Table 17 and the multivariate and univariate results are presented in Table 18 .

Insert Table 17 and 18 about here

Summary. Some evidence was found suggesting a longitudinal negative curvilinear relationship between mothers' negativity and their adolescents pubertal growth. Adolescents in stepfamily experienced greater decreases in maternal positivity than did teenagers in nondivorced families. No significant findings were emerged for father's parenting behavior:

Repeated Measures Analyses

Mothers' Parenting. The repeated measures analyses illuminated a number of findings relevant to cross-sectional and time-related patterns. Multivariate main effects for family type were found in maternal negativity and in maternal positivity. A significant pubertal growth by gender interaction was found for maternal control. A strong main effect for wave was evident for all measures of maternal parenting and significant wave interactions were found for pubertal growth (negativity), family type (positivity), and pubertal growth by family type (control). 
As predicted, maternal negativity increased over time, was higher in stepfamilies and higher for adolescents in early maturational phases (Wave 2).

As predicted maternal positivity decreased over time, was higher in nondivorced families than in stepfamilies (primarily at wave 2). Maternal control decreased over time, was greater for girls than for boys in the latter stages of pubertal growth and at Wave 2 was greater for adolescents in nondivorced homes than for teenagers in stepfamilies. The means and standard deviations and multivariate and univariate results are presented in Tables 19 and 20 respectively.

\section{Insert Table 19 and 20 about here}

In summary, strong trends were found for decreases in maternal positivity and control and increases for negativity over time. No consistent patterns were found indicating differences by pubertal growth groups. As expected, adolescents in stepfamilies endured higher levels of maternal negativity and experience less positivity than do adolescents in nondivorced homes. Maternal control was higher for girls in late puberty than for boys in the latter stages of puberty. 
Parent-Adolescent Relations and Puberty

Fathers' Parenting. The repeated measures analyses highlighted several findings relevant to cross-sectional and time-related patterns. Multivariate main effects were found for pubertal growth group (positivity and control), for family type (negativity and positivity) and, of course, for time (negativity, positivity and control). Significant multivariate interactions of family type, gender and pubertal growth group were found for paternal positivity and control.

The strong effects for time were in the expected directions, e.g., negativity increased, positivity and control decreased from Wave 1 to Wave 2 . No interactions involving time were indicated.

Paternal positivity was higher for adolescents in the early stages of maturation than for teenagers in the later phases of pubertal growth. Paternal control was less for adolescents in the later stages of puberty than for those who were not experiencing pubertal growth. Family type differences were consistent with adolescents in stepfamilies experiencing more päternal negativity and less positivity than teenagers in nondivorced homes. As was found with mothers, paternal control was higher for girls in the later stages of pubertal development than for boys in the last half of maturation. 
Parent-Adolescent Relations and Puberty

The three-way interactions were difficult to interpret. For paternal positivity inspection of the means and the significant univariate interactions indicated higher postivity for adolescents in the early phases of pubertal growth for boys and girls in nondivorced homes and girls in stepfamilies (both waves). Boys in stepfamilies had lower positivity regardless of the stage of pubertal development than boys who didn't change in pubertal status. The only relevant significant univariate findings found stepfamily girls in the Early-to-Mid pubertal growth group with higher positivity scores than stepfamily girls who did not change pubertal status and those who were moving through the later stages of puberty.

For paternal control similar patterns were found only for boys in nondivorced families and girls in stepfamilies (higher control for the Early-to-Mid group than for the No Change and Mid-to-Late group). Girls in nondivorced families had opposite patterns from Wave 1 to Wave 2 and boys in stepfamilies decreased from No Change to Early-toMid to Mid-to-Late. The distinctly differing patterns in the gender by family type groups may have resulted in the significant interaction.

In summary, strong effects were found for wave with paternal negativity increasing and with positivity and 
Parent-Adolescent Relations and Puberty

control decreasing over time. Paternal negativity was more likely in stepfamilies and positivity was more consistently found in nondivorced families. Adolescents in the first half of pubertal maturation experienced more paternal positivity than did teenagers in the later phases of pubertal growth while adolescents in the later stages of pubertal growth encountered less control than teenagers who were not experiencing pubertal growth. Parallel results found for mothers, paternal control was higher for girls in the later stages of pubertal development than for boys in the last half of maturation. In brief paternal control appeared to be marked by distinct patterns within gender and family type groups. Means and standard deviations and multivariate and univariate results are presented in Tables 21 and 22 .

Insert Table 21 and 22 about here

Exploratory Analyses Related to Biological 'Ownness'

Mothers' Parenting. As noted 'ownness' has recently been explored as an important grouping variable in understanding family relationships. There were insufficient numbers of stepmothers to conduct multivariate analysis using pubertal growth groups. The possibility of 'ownness' 
Parent-Adolescent Relations and Puberty

or differing relationships between maternal parenting behavior and the pubertal development of their adolescents by biological mother-child relationships versus stepmotheradolescent relationships was investigated using the analysis of covariance test for homogeneity of regression slope. The continuous curvilinear pubertal growth variable (CCPG) was utilized to test for differences in regression slopes among the gender by family type and ownness groups that were significantly different from the average regression slope.

No differences were found for maternal negativity or positivity, but did emerge for maternal control. The omnibus test was significant as was the test for family type and ownness, while the test of gender differences was not significant. Testing for differences between the family type and ownness groups indicated significant differences between the nondivorced group and the stepfamily group and specifically for girls in stepfamilies (with biological mother) versus girls in nondivorced families. The sign of the beta-weight indicated that for biological mothers and daughters in blended stepfamilies a significant positive quadratic relations between maternal control and pubertal growth meaning that control decreased during early pubertal development.

This relationship was not confirmed by the previous 
Parent-Adolescent Relations and Puberty

multivariate change score analyses. An examination of the pubertal growth group means does suggest a curvilinear relationship, but an independent univariate analysis of maternal control did not affirm this pattern via significant effects or interactions. Table 23 displays the beta weights and significance levels of homogeneity of regression tests.

Insert Table 23 about here

Fathers' Parenting. Analyses to illuminate possible differences specific to stepfather-adolescent relationships was undertaken in two ways: (1) multivariate analyses similar to previous analyses and (2) analyses of covariance for homogeneity of regression slope. The multivariate analyses should be regarded as preliminary at best because of the small cell sizes for the stepfather-adolescent cells and failure to meet the assumptions of multivariate analyses.

The multivariate analyses of difference scores produced one significant result: a three way interaction of gender, family type/ownness and pubertal growth group for paternal negativity. The significant univariate findings and the means suggest that girls and stepfathers displayed a strong negative quadratic curvilinear relationship across the 
pubertal growth groups. An additional pattern that may have contributed to the significant interaction is the strong linear increase in difference scores across pubertal growth groups for biological father-son relationships within stepfamilies (indicating decreases in paternal negativity for boys who did not change in pubertal status, increases in negativity for boys moving through the early stages of puberty and a greater increases for boys in the later phases of pubertal maturation). Biological father-daughter relationships in stepfamilies displayed the opposite pattern, i.e., larger increases in paternal negativity for girls who did not change pubertal status or who were moving through the early stages of puberty and smaller increases in negativity for girls who were completing their pubertal growth. Tables 24 and 25 contain the means, standard deviations, multivariate and univariate results for the difference scores analyses.

Insert Table 24 and 25 about here

The multivariate repeated measures analyses of the composite scores found family type/ownness effects for negativity and positivity, a gender by pubertal growth interaction for control, and three-way interactions for 
Parent-Adolescent Relations and Puberty

positivity and control. Of course, wave effects were present and a four-way interaction including time was found for negativity.

As expected the family type/ownness effects, indicated higher levels of paternal negativity and lower positivity in stepfather-adolescent relationships versus father-adolescent relationships in nondivorced homes. As has been found previously, girls in the later stages of pubertal growth experience higher levels of paternal control than do boys in the last half of pubertal development.

The three-way interactions are difficult to intrepret. For paternal positivity examination of the univariate findings and inspection of the means suggests the following: (1) girls in stepfather-adolescent relationships and somewhat less so for girls in nondivorced homes had a marked pattern of higher positivity for girls in the early stages of pubertal growth (versus girls who did not change in pubertal status or who were in the later phases of pubertal maturation), (2) a cross-sectional pattern of decreases in positivity across pubertal growth groups (No Change being the highest and Mid-to-Late the lowest) for boys in stepfather-son relationships and for boys in biological father-son relationships in blended stepfamilies and (3) the opposite cross-sectional trend for girls in father-daughter 
Parent-Adolescent Relations and Puberty

relationships within blended stepfamilies of increased positivity with later pubertal growth (over early pubertal growth and no change statuses).

Interestingly similar patterns were found for paternal control except for girls in nondivorced homes. The decreases in paternal control across pubertal growth groups (No Change highest; Mid-to-Late lowest) for boys in father-son relationships within blended stepfamilies was marked.

The four-way interaction with wave for paternal negativity showed similar cross-sectional trends for girls in stepfather relationships and girls in father-daughter relationships in blended stepfamilies. Boys in stepfatherstepson relationships mimic the pattern of girls in stepfather-stepdaughter relationships. The only strong wave difference in the trends appeared to be for boys in blended stepfamilies. Table 26 and 27 display the means, standard deviations, multivariate and univariate results for these exploratory analyses.

Insert Table 26 and 27 about here

The second set of exploratory analyses via tests of homogeneity of regression line failed to find any differences between the six gender by family type and 
Parent-Adolescent Relations and Puberty

ownness groups and the average regression line. There was no evidence of significantly different curvilinear relationships in (step) father-adolescent relationships across the three parenting variables.

Summary of Parenting Behavior Related to Biological 'Ownness'. Exploratory analyses found evidence for a longitudinal positive curvilinear relationship between pubertal growth and mother's control behavior for biological mother-daughter dyads in blended stepfamilies. Stepfatherdaughter relationships appeared to have a negative curvilinear relationship for fathers' negativity and possibly a positive curvilinear relationships for paternal positivity. There were a number of distinct patterns in the family type by gender groups making interpretation difficult. It was clear that patterns varied by gender and family type.

\section{Mothers' Reports of Parenting Behavior}

\section{Difference Score Analyses}

Mothers' Parenting. No significant results emerged from the multivariate analyses of difference scores. Thus there was no evidence for strong curvilinear longitudinal patterns in mothers' reports of their own parenting behavior. Tables 28 and 29 contain the means, standard deviations and multivariate results. 
Parent-Adolescent Relations and Puberty

Insert Table 28 and 29 about here

\section{Repeated Measures Analyses}

Mothers' Parenting. The repeated measures analyses resulted in only three multivariate findings: a strong wave effect, a gender effect (for control) and a pubertal growth group effect (for control). As expected the wave effects were robust increases for negativity and vigorous decreases for postivity and control. A main effect for pubertal growth group indicated consistently higher control scores for adolescents in early phases of pubertal maturation than teenagers in later stages of growth. An overall gender difference emerged with mothers' perceiving more control behavior toward their daughters than with their sons. other tentative findings emerged as significant univariate results without a corresponding significant multivariate finding. A second cross-sectional pubertal growth group difference (negativity), family type difference (positivity) and two interations (negativity and control). The pubertal growth group difference for negativity was the same as for control (Early-to-Mid greater than Mid-to-Iate). Positivity scores for nondivorced families were higher than for stepfamilies. A pubertal growth group by gender 
interaction for control indicated that for adolescents in the later half of pubertal maturation, mothers perceived more control for girls than for boys. A three-way interaction for negativity appeared to be related to a strong decrease in negativity scores across pubertal change groups (No Change highest, Mid-to-Late lowest) for boys in stepfamilies and opposite patterns for girls in nondivorced or stepfamilies. For nondivorced girls, those in Early-toMid pubertal growth groups had lower scores than those in the No Change and the Mid-to-Late groups. While for stepfamily girls the Earlyto-Mid was the highest. Tables 30 and 31 present the means, standard deviations, multivariate and univariate results.

Insert Table 30 and 31 about here

\section{Summary of Mothers' Reports}

Mothers' reports of their own parenting did not appear to have significant curvilinear longitudinal patterns. As usual there were the strong wave effects, perceptions of higher levels of control toward adolescents in the earlier phases of pubertal growth versus teenagers in the later stages of maturity and greater control behavior toward girls than for boys. Exploratory findings include the same 
Parent-Adolescent Relations and Puberty

pubertal growth group findings for negativity scores, the finding previously reported of higher control scores for more developed girls than for more developed boys and higher positivity scores for mothers of adolescents in nondivorced families than in stepfamilies.

Adolescents' Reports of Parenting Behavior

\section{Difference Score Analyses}

Mothers Parenting. Multivariate analyses of the difference scores of adolescents' perceptions of their mothers' parenting revealed a main effect for family type (negativity) and a three-way interaction (control). Adolescents in stepfamilies felt there was a greater increase in maternal negativity than did teenagers in nondivorced homes. The interaction appears to reflect the opposite patterns found for girls' reports of mothers in nondivorced versus stepfamily homes. Based on the means, mothers' control in nondivorced homes showed a strong curvilinear pattern indicating greater increases in control during development from early to mid-puberty. However maternal behavior in stepfamilies displayed a negative curvilinear trend of larger decreases in control during maturation from early to mid-puberty.

A tentative finding that was not significant at the multivariate level was a family by gender interaction for 
Parent-Adolescent Relations and Puberty

control. An examination of the means suggested that the difference was the same family type difference noted above within girls. Means, standard deviations and the multivariate and univariate findings are reported in Tables 32 and 33 .

Insert Table 32 and 33 about here

Fathers' Parenting. There was only one multivariate finding for adolescents' report of their father's parenting. Adolescents in stepfamilies perceived greater decreases in positivity from Wave 1 to Wave 2 than did teenagers in nondivorced homes. The means, standard deviations and multivariate results are presented in Tables 34 and 35 .

Insert Table 34 and 35 about here

Summary. Adolescent reports via difference scores resulted in family type differences (greater increases in maternal negativity and larger decreases in paternal positivity for adolescents in stepfamilies versus adolescents in nondivorced homes) and contrasting longitudinal patterns for maternal control as perceived by girls in stepfamilies versus females in nondivorced 
families. Girls in nondivorced homes reported increases in maternal control behavior during early pubertal development while females in stepfamilies depicted decreases.

\section{Repeated Measures Analyses}

Mothers' Parenting. The repeated measures analyses resulted in a significant family type difference (negativity), wave effects (positivity and control), a wave by family type interaction and a four-way interaction that included wave, gender, family type and pubertal growth group (control). As has been typical, wave effects indicated perceptions of decreased maternal positivity and control, but interestingly adolescents did not report a significant increase in maternal negativity over time.

The family type difference indicated that adolescents' in stepfamilies reported their mothers as exhibiting more negative behavior than did teenagers in nondivorced families particularly at wave 1. The four-way interaction for maternal control is difficult to decipher. Additionally, two three-way interactions for control were significant at the univariate level, but not the multivariate level. The significant comparisons suggest that there were several differences at Wave 2 (versus Wave 1), that within a specific gender (girls) and/or pubertal growth groups (No Change) those in stepfamilies indicated lower control 
Parent-Adolescent Relations and Puberty

behavior than did adolescents in nondivorced homes. The differing patterns noted above between females in stepfamilies and those in nondivorced home may be reflected in the interaction in that some of the changes appear to be greater by wave. Means, standard deviations, multivariate and univariate findings are reported in Tables 36 and 37 .

Insert Table 36 and 37 about here

Father's Parenting. The multivariate repeated measures analyses, similar to the difference score analyses, found family type differences (negativity and positivity), wave effects (control) and one wave-by-family-type interaction (positivity). Adolescents did not perceive significant shifts in paternal behavior except for a significant drop in paternal control behavior. As expected for family type differences, adolescents in stepfamily felt they were treated more negatively and less positively by their fathers than did teenagers in nondivorced households. This difference for positivity was primarily found at wave 2 .

Insert Table 38 and 39 about here

Summary. The repeated measures analyses highlighted 
Parent-Adolescent Relations and Puberty

several cross-sectional and across-time patterns. Interestingly adolescents did not report increases in negativity over time for either fathers or mothers. Positivity was perceived as decreasing with time only for mothers and control was seen as decreasing for both mothers' and fathers' parenting. Both mothers and fathers were seen as exhibiting more negativity and fathers as showing less positivity in stepfamilies than in nondivorced households. Significant interactions suggested contrasting crosssectional patterns in maternal control for girls in nondivorced homes versus stepfamilies.

\section{Pubertal Timing and Parenting}

\section{Repeated Measures}

Because of the small sample for which pubertal timing was available, pubertal growth groups were not included in these analyses. Thus only the multivariate repeated measures analyses were completed to illuminate pubertal timing by family type differences. The multirespondent composites were utilized as measures of parenting behavior.

Mothers' Parenting. The multivariate analyses revealed no significant differences in mother's parenting except for the wave effects that have been previously reported. While the trends in the means suggested the expected differences for girls who were early maturer versus those who were on- 
Parent-Adolescent Relations and Puberty

time or late maturers, e.g., higher negativity, lower positivity and lower control, these observed trends were not significant.

Insert Table 40 and 41 about here

Fathers' Parenting. For unknown reasons there were relatively few girls with pubertal timing data who were biological daughters in stepfamilies. Thus these analyses focused on differences between father-daughter dyads in nondivorced homes and stepfather-daughter pairs. Unfortunately the analyses of father's behavior were not much more exciting than for those regarding mothers' parenting behavior. Again the expected wave effect appeared. There was a tentative univariate finding

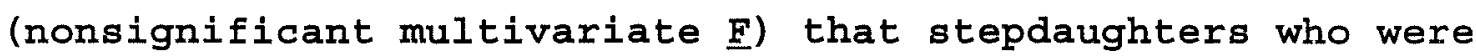
on time in their pubertal maturation received less paternal positivity than did biological daughters in nondivorced families.

Insert Table 42 and 43 about here 
Parent-Adolescent Relations and Puberty

\section{Discussion}

\section{Curvilinear Relationships between parenting and pubertal} development

The first major issue that was addressed in this paper was assessing evidence supporting a longitudinal curvilinear relationships between parenting and pubertal growth. The clearest evidence of a curvilinear pattern was mothers' negativity based on the composites. That is, mothers' negativity increased more as their sons and daughters matured from early to mid-puberty than did mothers' whose teenagers moved from mid-to-late puberty or mothers whose adolescents did not experience substantial pubertal growth. Exploratory analyses of maternal control indicated a curvilinear relationship for mother and daughters in stepfamilies versus mother-daughter dyads in nondivorced families. An interaction from the MANOVA analyses supports differing patterns for mothers and daughters in nondivorced versus stepfamilies.

The only empirical support for a curvilinear relationship for paternal behavior came from the exploratory analyses. For stepfather-daughter relationships paternal negativity appeared to be significantly related to pubertal growth. Increases in negativity during the early phases of pubertal growth were found suggesting the hypothesized 
negative quadratic relationship.

Adolescent reports of maternal control indicated opposite patterns via interactions for girls in nondivorced households versus girls in stepfamilies. Girls in nondivorced homes perceived a substantial increase in maternal control during the first half of pubertal development while girls in stepfamilies in the same maturational phase reported a large decrease in maternal control. There were no significant findings for adolescent reports of paternal behavior.

These findings are consistent with the literature. The curvilinear patterns found for maternal negativity are compatible with the patterns reported by steinberg (1988, 1981) and steinberg and Hill (1978). The findings for maternal control and paternal negativity support a notion of discrepant patterns by family type for girls as suggested by Anderson, Hetherington and Clingempeel (1989).

Across-Wave Trends in Parenting Behavior

The strongest and most consistent findings were increases in the degree of parental negativity and decreases in the levels of parental positivity and control regardless of adolescent pubertal development or gender. Given the consistency and large values of the $\underline{F}$ tests, these linear patterns over time provide the best overall expectation of 
Parent-Adolescent Relations and Puberty

changes in parenting behavior. Similar results have been widely reported in the literature. These results integrated with those from the analyses above suggest that at least for parental negativity and maternal control in some family types, a linear plus a curvilinear effect may best describe the relationship between parental behavior and adolescent pubertal development.

Interestingly adolescents do not agree with the strong linear trends in parental behavior for parental negativity and paternal positivity. It is unclear why adolescents may feel this way. Measurement artifacts may have played a role. It was assumed that adolescents would interpret and respond to the questionnaires in basically the same manner as the adults. Presumably adults are responding to perceptions of recent and long-term trends and changes in interaction patterns or are contrasting the target relationship with other parent-child relationships. Adolescents may tend to oversimiplify parent-adolescent relations into two discrepant perceptions of either "things are bad" or "things are good". While not formally tested, even a cursory inspection of the standard deviations for composites and mothers' reports versus the adolescent reports reveals that the standard deviations for adolescents are often twice as large as those for the composites and 
mothers' reports.

\section{Family Type Differences}

The repeated measures findings were very consistent across reporters in revealing family type differences in absolute levels of parental behavior. Adolescents in stepfamilies endured more parental negativity and less positivity than teenagers in nondivorced homes. No family type differences were found for parental control behavior. These results mirror those of Anderson, Hetherington and Clingempeel (1989) and highlight the importance of not generalizing findings across family types. Few researchers have included these important distinguishing characteristics in their investigations of family relationships. Gender and Cross-Gender Parent-Adolescent Relationships

The only gender effect to emerge was a consistent interaction with pubertal growth indicating greater maternal and paternal control behavior toward their late pubertal girls versus their late pubertal boys. A more accurate interpretation may be that control behavior directed at girls decreases less sharply than it does for boys during late pubertal maturation. The literature has not suggested dependable patterns for parental control perhaps in part because of the wide range of measures and mix of theoretical constructs. Anderson, Hetherington and Clingempeel (1989) 
Parent-Adolescent Relations and Puberty

data are the closest in terms of measurement of control, but their results are divided by family type and overall gender differences are not reported.

It is not clear from this data that cross-gender parent-adolescent interactions are more difficult or extreme when compared to same-gender parent-adolescent relationships. While there was some interactions related to father-daughter relationships, the interactions included family type suggesting that the impact of cross-gender parent-adolescent differs by family. Stepfathers and daughters appear to have more extreme scores than other father-daughter relationships.

\section{Biological 'Ownness' versus Stepfather-Adolescent}

\section{Relationships}

For stepfathers and stepdaughters somewhat ambivalent evidence emerged suggesting the expected curvilinear relationship for paternal negativity. Flatter patterns were found for fathers and daughters in nondivorced and stepfamilies. Fathers and sons in nondivorced households and stepfathers and stepsons also displayed less extreme trends. The pattern of means in stepfathers and stepsons, however showed a strong linear trend across pubertal groups.

The repeated measures analyses suggested distinct patterns by family type and biological relationship for 
Parent-Adolescent Relations and Puberty

paternal positivity and control as well. Within each of the three groups the patterns for boys and girls were reasonably similar when comparing paternal positivity and control. Father-adolescent dyads in stepfamilies and stepfatherstepdaughter pairs appeared to have the most extreme scores. Henderson and Hetherington (1992) have also found differences in stepfather-adolescent relationships as compared to father-adolescent relationships in stepfamilies and nondivorced household for positivity in particular.

As noted above these analyses can only be considered as exploratory. They are provocative, but can not be touted as clear evidence of specific patterns for parent-adolescent dyads and stepparent-adolescent pairs. These findings should, however, remind researchers that family characteristics such as biological relatedness appear to predict distinct patterns in parent-adolescent relationships, particularly in stepfather-daughter dyads. Pubertal Timing and Parent-Adolescent Relationships

The analyses investigating pubertal timing were disappointing. A large number of cases were necessarily dropped from these analyses because of missing pubertal timing data. The missing cases were not uniformly distributed over family types and may have affected the results. No significant multivariate results were found 
Parent-Adolescent Relations and Puberty

related to pubertal timing.

\section{Future Research}

Several of the findings listed above contribute to the literature. Implications from this research include the following. First, there does appear to be usefulness to assessing curvilinear relationships between parenting behavior and pubertal development. As shown above, all parent-adolescent dyads do not experience the same pattern of change and an important potential predictor of those patterns is family type and biological relatedness. Curvilinear trends rather than linear patterns suggest a period of increased vulnerability for youths who are not only attempting to manage physical development and the associated changes, but must also cope with accelerated changes in how parents respond to them. Such findings also should remind researchers and consumers of such studies of the inappropriateness of generalizing across diverse family groups.

Second, clearly biological relatedness has importance in understanding parent-adolescent relationships. Much of the available research focuses on adolescents in nondivorced families. As the number of stepfamilies increase, consideration of biological relatedness becomes critical. Third, additional research is needed to understand the 


\section{Parent-Adolescent Relations and Puberty}

directionality of effects. This project did not investigate causuality or bidirectionality. Of course the possibility remains that adolescents' behavior alters as they move through puberty and parents are responding to their teenagers behavioral shifts. 
Parent-Adolescent Relations and Puberty

References

Anderson, E.R., Hetherington, E.M., \& Clingempeel, W.G. (1989). Transformations in family relations at puberty: Effects of family context. Journal of Early Adolescent Research, $9,310-334$.

Armentrout, J.A. \& Burger, G.K. (1978). Children's reports of parental child-rearing behavior at five grade levels. Developmental Psychology, 7, 44-48.

Baumrind, D. (1978). Parental disciplinary patterns and social competence in children. Youth and Society, 9, $239-$ 276 .

Baumrind, D. (1979). Adolescent Q-sort. Family socialization and developmental competence project. University of California, Institute of Human Development, Berkeley.

Baumrind, D. (1991). Effective parenting during the early adolescent transition. In P.A. Cowan and E.M. Hetherington (Eds.), Family Transitions (pp. 111-163). Hillsdale, NJ: Lawrence Erlbaum. 
Parent-Adolescent Relations and Puberty

Blos, P. (1979). The adolescent passage. New York: International Universities Press.

Brooks-Gunn, J., Attie, I., Burrow, C., Rosso, J.T., \& Warren, M.P. (1989). The impact of puberty on body and eating concerns in athletic and nonathletic contexts. Journal of Early Adolescence, 9, 269-290.

Brooks-Gunn, J. \& Warren, M.P. (1989). Biological contributions to affective expression in young adolescent girls. Child Development, 60,40-55.

Brooks-Gunn, J., Warren, M.P., Rosso, J. \& Gargiulo, J. (1987). Validity of self-report measures of girls' pubertal status. Child Development, 58, 829-841.

Brooks-Gunn, J. \& Zahaykevich, M. (1989). Parent-child relationships in early adolescence: A developmental perspective. In K.Kreppner \& R. M. Lerner (Eds.), Family systems and life-span development (pp. 223-246). Hillsdale, NJ : Erlbaum.

Caine, N. (1986). Behavior during puberty and adolescence. In G. Mitchell \& J.Erwin (Eds.), Comparative primate 
Parent-Adolescent Relations and Puberty

biology: Vol. 2A. Bheavior, conservation, and ecology (pp. 327-361). New York: Alan R. Liss.

Caspi, A. \& Moffitt, T.E. (1991). Individual differences are accentuated during periods of social change: The sample case of girls at puberty. Journal of Personality and Social Psychology, 61, 157-168.

Caspi, A., Lynam, D., Moffitt, T.E. \& Silva, P.A. (1993). Unraveling girls' delinguency: Biological, dispositional, and contextual contributions to adolescent misbehavior. Developmental Psychology, 29, 19-30.

Chodorow, N. (1978). The reproduction of mothering: Psychoanalysis and the sociology of gender. Berkley, CA: University of California Press.

Cohen, J. (1968). Weighted Kappa: Nominal scale agreement with provision for scale disagreement or partial credit. Psychological Bulletin, 70, 213-220.

Cohen, Y. (1964). The transition from childhood into adolescence. Chicago: Aldine. 
Parent-Adolescent Relations and Puberty

Cooper, C.R. (1988). Commentary: The role of conflict in adolescent-parent relationships. In M.R. Gunnar \& W.A. Collins (Eds.), Development during the transition to adolescence: Minnesota symposia on child psychology. (Vol. 21, pp. 181-187). Hillsdale, NJ: Erlbaum.

Cooper, C.R. \& Ayers-Lopez, S. (1985). Family and peer systems in early adolescence: New models of the role of relationships in development. Journal of Early Adolescence, 5, $9-21$.

Dubas, J.S., Graber, J.A. \& Peterson, A.C. (1991). A longitudinal investigation of adolescents' changing perceptions of pubertal timing. Developmental Psychology, $\underline{27}, 580-586$.

Freud, A. (1936). The ego and the mechanisms of defense. New York: International Universities Press.

Freud, A. (1958). Adolescence. Psychoanalytic Study of the Child, 13, 255-278.

Garguiulo, J., Attie, I., Brooks-Gunn, J., \& Warren, M.P. (1987). Dating middle-school girls: Efects of social 
Parent-Adolescent Relations and Puberty

context, maturation, and grade. Developmental Psychology, $\underline{23(5)}, 730-737$.

Grotevant, H.D. \& Cooper, C.R. (1986). Individuation in family relationships: A perspective on individual differences in the development of identity and role-taking skill in adolescence. Human Development, 29, 82-100.

Hartup, W.W. (1989). Social relationships and their developmental significance. American Psychologist, $\underline{44}, 120$ 126 .

Henderson, S. \& Hetherington, E.M. (1992). [Owness and parent-adolescent relationships]. Unpublished raw data. University of virginia.

Hetherington, E.M. (1972). Effects of father absence on personality development in adolescent daughters. Developmental Psychology, 26, 97-136.

Hetherington, E.M. (1988). Parents, children, and siblings six years after divorce. In $\mathrm{R}$. Hinde \& J. Stevenson-Hinde (Eds.), Relationships within families: Mutual influences, (pp. 49-67). Lexington, MA: D.C. Heath. 
Parent-Adolescent Relations and Puberty

Hetherington, E.M. \& Clingempeel, W.G. (1992). Coping with marital transitions: A family systems perspective. Monographs of the Society for Research in Child Development, $57(2-3)$. Serial No. 227 .

Hill, J.P. (1988). Adapting to menarche: Familial control and conflict. In M. Gunnar \& W. A. Collins (Eds.), Development during transition to adolescence: Minnesota symposia on child psychology, (Vol. 21, pp. 43-77). Hillsdale, NJ: Lawrence Erlbaum.

Hill, J.P., Holmbeck, G.N., Marlow, L., Green, T.M., \& Lynch, M.E. (1985a). Menarcheal status and parent-child relations in families of seventh-grade girls. Journal of Youth and Adolescence, 14, 301-316.

Hill, J.P., Holmbeck, G.N., Marlow, L., Green, T.M., \& Lynch, M.E. (1985b). Pubertal status and parent-child relations in families of seventh-grade boys. Journal of Early Adolescence, $\underline{5}, 31-44$.

Hunter, F. \& Youniss, J. (1982). Changes in functions of three relations during adolescence. Developmental Psychology, 18, 806-811. 
Inhelder, B. \& Piaget, J. (1958). The growth of logical

thinking. (A. Parsons and S. Milgram, trans). New York: Basic Books.

Inoff-Germain, G., Arnold, G.S., Nottelmann, E.D., Susman, E.J., Cutler Jr., G.B., \& Chrousos, G.P. (1988). Relations between harmone levels and observational measures of aggressive behavior of young adolescents in family interactions. Developmental Psychology, 24, 129-139.

Katz, M.B. (1975). The people of Hamilton, Canada West: Family and class in a mid-nineteenth century city. Cambridge, MA: Harvard University Press. [historical, adolescents emigrated from family group at puberty].

Maccoby, E.E. \& Martin, J.A. (1983). Socialization in the context of the family: Parent-child interaction (pp. 1-102). In P. H. Mussen (Ed.), Handbook of Child Psychology, (4th ed.), E. M. Hetherinton (Vol. Ed.), Socialization, personality, and social development. New York: John Wiley and Sons.

Magnusson, D., Stattin, H., \& Allen, V. (1985). Biological maturation and social development: A longitudinal study of 
Parent-Adolescent Relations and Puberty

some adjustment processes from midadolescence to adulthood. Journal of Youth and Adolescence, 14, 267-284.

Mekos, D. (1991). Changes in Family Relations and Pubertal Status: A Closer Look at the Distancing and Acceleration Hypothesis. Unpublished master's thesis, University of Virginia.

Mekos, D., Hetherington, E.M., Clingempeel, W.G. \& Reiss, D. (1992, March) . Relations between father absence, family quality and pubertal development. Paper presented as a part of the symposium "Psychosocial antecedents of the timing of puberty at the biennial meeting of the Society for Research on Adolescence, Washington, D.C.

Montemayor, R. (1983). Parents and adolescents in conflict: All families some of the time and some families most of the time. Journal of Early Adolescence, 3, 83-103.

Montemayor, R. (1986). Family variation in parent-adolescent storm and stress. Journal of Adolescent Research, 1, 15-31.

Montemayor, R. \& Hanson, E.A. (1985). A naturalistic view of conflict between adolescents and their parents and siblings. 
Parent-Adolescent Relations and Puberty

Journal of Early Adolescence, $\underline{5}, 23-30$.

Muuss, R.E. (1982). Theories of Adolescence (4th ed.). New York: Random House.

Olweus, D., Block, J., \& Radke-Yarrow, M. (1986).

Development of antisocial and prosocial behavior: Research, theories and Issues. Orlando, FL: Academic Press.

Paikoff, R.I. \& Brooks-Gunn, J. (1991). Do parent-child relationships change during puberty? Psychological Bulletin, 110, 47-66.

Paikoff, D.R., Collins, W.A. \& Laursen, B. (1986). Perceptions of efficacy and legitimacy of parental influence techniques by preadolescents and adolescents. Manuscript under review.

Papini, D.R., Datan, N., \& McCluskey-Fawcett, K.A. (1988). An observational study of affective and assertive family interactions during adolescence. Journal of Youth and Adolescence, 17, 477-492.

Papini, D.R. \& Sebby, R.A. (1985, April). Multivariate 
Parent-Adolescent Relations and Puberty

assessment of adolescent physical maturation as a source of family conflict. Paper presented at the Changing Family Conference XIV: Adolescents and Families, University of Iowa, Iowa City, IA.

Papini, D., \& Sebby, R. (1987). Adolescent pubertal status and affective family relationships: A multivariate assessment. Journal of Youth and Adolescence, 16, 1-15.

Patterson, G.R. (1982). Coercive family process: Vol. 3. A social learning approach. Eugene, OR: Castalia.

Peterson, A.C. (1985). Pubertal development as a cause of disturbance: Myths, realities and unanswered questions. Journal of Genetic Psychology Monographs, 111, 207-231.a

Petersen, A.C., Crockett, L., Richards, M. \& Boxer, A. (1988). A self-report measure of pubertal status: Reliability, validity and initial norms. Journal of Youth and Adolescence, 17, $117-133$.

Savin-Williams, R. \& Small, S. (1986). The timing of puberty and its relationship to adolescent and parent preceptions of family interactions. Developmental Psychology, 22, 322-347. 
Parent-Adolescent Relations and Puberty

Simmons, R.G. \& Blyth, D. (1987). Moving into adolescence: The impact of pubertal change and school context. New York: Aldine De Gruyter.

Simmons, R.G., Blyth, D.A. \& McKinney, K.L. (1983). The social and psychological effects of puberty on white females. In J. Brooks-Gunn \& A.C. Peterson (Eds.), Girls at puberty: Biological and psychosocial perspectives (pp. 229272). New York: Plenum Press.

Smetana, J.G. (1988). Concepts of self and social convention: Adolescents' and parents' reasoning about hypothetical and actual family conflicts. In M. Gunnar \& W.A. Collins (Eds.), Development during transition to adolescence: Minnesota syumposia on child psychology (Vol. 21, Pp. 79-122). Hillsdale, NJ: Lawrence Erlbaum.

Steinberg, L.D. (1977). A longitudinal study of physical growth, intellectual growth, and family interactions in early adolescence. Unpublished doctoral dissertation, Cornell University.

steinberg, L.D. (1981). Transformation in family relations at puberty. Developmental Psychology, 17, 833-840. 
Parent-Adolescent Relations and Puberty

Steinberg, L. (1985, March 6-8). The ABCs of transformations in the family at adolescence: Changes in affect, behavior and cognition. Paper presented at the 3 rd Biennial Conference on Adolescent Research, Tucson, Az.

Steinberg, L.D. (1987). The impact of puberty on family relations: Effects of pubertal status and pubertal timing. Developmental Psychology, 23, 833-840.

Steinberg, L.D. (1988). Reciprocal relation between parentchild distance and pubertal maturation. Developmental Psychology, 24, 122-128.

Steinberg, L.D. (1989). Pubertal maturation and family relations: Evidence for the distancing hypothesis. In G. Adams, R. Montemayor, \& T. Gullotta (Eds.), Advances in adolescent development (Vol. 1), pp. 71-97. Newbury Park, CA: Sage.

Steinberg, L.D. (1990). Interdependence in the family: Autonomy, conflict and harmony in the parent-adolescent relationship. In S.S. Feldman \& G.R. Elliott (Eds.), At the threshold: The developing adolescent. Cambridge, MA: Harvard University Press. 
Parent-Adolescent Relations and Puberty

Steinberg, L.D. \& Hill, J.P. (1978). Patterns of family interaction as a function of age, the onset of puberty, and formal thinking. Devlopmental Psychology, 14, 683-684.

Straus, M.A. (1979). Measuring intrafamily conflict and violence: The Conflict Tactics (СT) Scales. Journal of Marriage and the Family; $41,75-85$.

Sussman, E., Inoff-Germain, G., Mottelmann, E., Cutler, G., Jr., \& Chrousos, G. (1987). Hormones, emotional dispositions and aggressive atytributes in early adolescents. Child Development, $\underline{58}, 1114-1134$.

Tabachnick, B. \& Fidell, L. (1989). Using Multivariate Statistics. San Francisco, CA: Harper \& Row.

Tanner, J.M. (1970). Physical growth. In P.H. Mussen, (Ed.) Carmichael's Manual of Child Psychology, 3rd Edition, Vol. 1, (pp. 77-155). New York: Wiley.

Youniss, J. (1975). Another perspective on social cognition. In A. D. Pick (Ed.), Minnesota symposia on Child Psychology (Vol. 9). Minneapolis, University of Minnesota Press. 
Parent-Adolescent Relations and Puberty

Youniss, J., \& Smollar, J. (1985). Adolescent relations with mothers, fathers and friends. Chicago: University of Chicago Press.

Zill, N. \& Furstenberg, F.F. (1981). National Survey of Children: Wave 2. Unpublished measure. 
TABLE 1.

SAMPLE DEMOGRAPHIC CHARACTERISTICS.

\section{SUBJECT CHARACTERISTICS}

AGE IN YEARS (WAVE1) AGE IN YEARS (WAVEZ) DIFFERENCE IN AGE (H2-H1)

$\frac{\text { MALES }}{\text { MEAN (Sd) MIN MAX }} \frac{\text { FEMALE }}{\text { MEAN (Sd) MIN MAX }}$

$\begin{array}{rrrrrrrr}12.2(1.9) & 10 & 18 & 12.1 & (2.0) & 9 & 18 \\ 14.8(1.8) & 12 & 20 & 14.6(1.9) & 12 & 20 \\ 2.6(0.6) & -- & -- & 2.5 & (0.6) & -- & --\end{array}$

MALES MEAN (Sd) MIN MAX

$37.4(5.8) 29 \quad 53$

$40.1(6.0) 2765$

$5.0(1.3) 17$

4.9 (1.1) 27

$99 \%$

$84 \%$ $\frac{\text { FEMALE }}{\text { MEAN (Sd) MIN MAX }}$

$38.0(4.9) \quad 27 \quad 51$

$40.6(6.4) \quad 26 \quad 66$

$4.9(1.1) \quad 27$

$4.9(1.3) 17$

\section{FATHER AGE \\ MOTHER EDUCATION ${ }^{1}$ \\ FATHER EDUCATION'}

PERCENT OF FATHERS EMPLOYED PERCENT OF MOTHERS EMPLOYED

\section{FAMILY CHARACTERISTICS}

MUNBER OF CHILDREN
SES (HOLLINGSHEAD)

\section{$\frac{\text { MALES }}{\text { MEAN (Sd) MIN MAX }}$}

$\begin{array}{crr}3.1(1.2) & 2 & 8 \\ 43.0(10.3) & 17 & 66\end{array}$

INTACT FAMILIES STEPFAMILIES

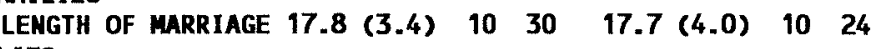

LENGTH OF MARRIAGE

$9.9(3.7) \quad 1 \quad 18$

$8.4(3.5) \quad 116$

PERCENT IN INTACT FAMILIES

$\frac{\text { PERCENT }}{50 \%} \frac{\text { NUM }}{100} \quad \frac{\text { PERCENT }}{53 \%} \frac{\text { NUM }}{100}$

PERCENT IN STEPFAMILIES MOTHER'S BIOLOGICAL CHILD FATHER'S BIOLOGICAL CHILD

$\begin{array}{rrrr}50 \% & 100 & 47 \% & 89 \\ 87 \% & 87 & 89 \% & 79 \\ 46 \% & 46 & 37 \% & 33\end{array}$

1 Education level ranged from '1' meaning less than 7 years of formal education to '7' representing doctoral level training. A value of '4' represents a high school graduate and a level of ' 5 ' equals some college level training (less than a Bachelor's degree). 
TABLE 2.

PARENTING COAPOSITES: VARIABLES AND REPORTERS.

\section{COMPOSITE VARIABLES}

\begin{tabular}{|c|c|}
\hline $\begin{array}{c}\text { Questionnaire } \\
\text { Measures }\end{array}$ & ob \\
\hline Child 2 and Parent & $\mathrm{H}$ \\
\hline
\end{tabular}

\section{PARENTAL POSITIVITY}

Warmth/Support Communication Assertiveness Involvement

PARENTAL NEGATIVITY

Conflict (2 measures) Punitive Discipline Symbolic Aggression

Anger/Rejection Coercion

Transactional Conflict

\section{PARENTAL CONTROL}

Attempted Control Actual Control

Authority/Control

Parental Influence 
TABLE 3.

INTERITEM-TOTAL CORRELATIONS AND CRONBACH ALPHAS FOR PUBERTAL ITEMS.

$\underline{\text { GIRLS }}$

Combined Ratings

Girls' Ratings Mothers' Ratings Wave 1 Wave 2

Pubertal I tems

Wave 1 Wave 2 Have 1 Wave 2 Girls/Mom Girls/Mom

1. Bocty Hair

$\begin{array}{lll}.74 & .59 & .84\end{array}$

$\begin{array}{lllll}.76 & .79 & .87 & .64 & .79\end{array}$

2. Breast Development

$.60 \quad-80$

$\begin{array}{lllll}.70 & .77 & .83 & .68 & .70\end{array}$

3. Menarche

.68

$.54 \quad .77$

$\begin{array}{llllll}.57 & .79 & .81 & .67 & .66\end{array}$

PDS Total Score

4. Cronbach Alpha

BOYS

\begin{tabular}{lllll} 
Boys' Ratings & & \multicolumn{2}{c}{ Combined Ratings } \\
\cline { 4 - 5 } & Mothers' Ratings & Have 1 & Have 2 \\
Have 1 Have 2 & Have 1 & Have 2 & Boys/Mom Boys/Mom
\end{tabular}

Pubertal Items

$\begin{array}{lllllllll}\text { 1. Body Hair } & .60 & .58 & .75 & .76 & .68 & .75 & .63 & .76 \\ \text { 2. Voice Changes } & .70 & .64 & .79 & .80 & .71 & .77 & .69 & .82 \\ \text { 3. Facial Hair } & .67 & .70 & .76 & .81 & .68 & .75 & .76 & .81\end{array}$

PDS Total Score

4. Cronbach Alpha

$.78 \quad .87$

.89

.89

.91 
TABLE 4.

INTERRATER RELIABILITIES FOR PUBERTAL RATINGS

FEMALES

MALES

Breast Development

Mensus Began

PDS SCALE SCORE

Pubertal Stage
Mother and Daughter Ratings: Wave 1 Mother and Daughter Ratings: Wave 2

\begin{tabular}{|c|c|c|c|c|c|c|c|c|c|}
\hline & & $\begin{array}{l}\text { Agree } \\
\text { within }\end{array}$ & & $\begin{array}{l}\text { Cohen's } \\
\text { Weighted }\end{array}$ & & & $\begin{array}{l}\text { Agree } \\
\text { within }\end{array}$ & & \\
\hline m & & One & Corr & Kappa & Num & Agree & One & Corr & \\
\hline
\end{tabular}

$\begin{array}{cccccccccc}186 & 65 \% & 94 \% & .78^{\star \star \star} & .68 & 185 & 69 \% & 98 \% & .60^{\star \star \star} & .54 \\ 189 & 68 \% & 98 \% & .76^{\star \star \star} & .66 & 185 & 64 \% & 97 \% & .65^{\star \star \star} & .53 \\ 193 & 98 \% & -- & -- & .96 & 186 & 98 \% & -- & -. & .92 \\ 183 & 69 \% & 97 \% & .88^{\star \star \star} & .75 & 186 & 78 \% & 99 \% & .74^{\star \star \star} & .70\end{array}$

Mothers' and Sons' Ratings: Wave 1 Mothers' and Sons' Ratings: Wave 2

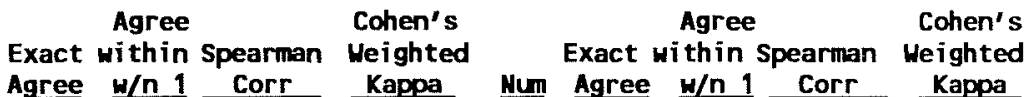

ITEM LEVEL

$\begin{array}{lllllllllll}\text { Body Hair } & 195 & 52 \% & 89 \% & .66^{\star \star \star} & .47 & 183 & 55 \% & 94 \% & .53^{\star \star \star} & .41 \\ \text { Voice Change } & 194 & 58 \% & 93 \% & .60^{\star \star \star} & .48 & 186 & 50 \% & 94 \% & .65^{\star \star \star} & .52 \\ \text { Facial Hair } & 195 & 68 \% & 95 \% & -62^{\star \star \star} & .50 & 186 & 50 \% & 98 \% & .72^{\star \star *} & .50\end{array}$

PDS SCALE SCORE

$\begin{array}{lllllllllll}\text { Pubertal Stage } & 190 & 48 \% & 86 \% & .67 * \star * & .49 & 182 & 54 \% & 97 \% & .73^{\star \star *} & .55\end{array}$ 
TABLE 5.

PUBERTAL STAGES FOR MALES AND FEMALES AS RATED BY COMBINED AND INDIVIDUAL REPORTERS.

BOYS UAVE 1

\begin{tabular}{|c|c|c|c|c|c|c|c|c|c|}
\hline \multirow[b]{2}{*}{$\begin{array}{l}\text { PUBERTAL } \\
\text { STAGE }\end{array}$} & \multicolumn{3}{|c|}{$\begin{array}{l}\text { COHBINED } \\
\text { RATINGS }\end{array}$} & \multicolumn{3}{|c|}{$\begin{array}{l}\text { ADOLESCENT } \\
\text { RATINGS }\end{array}$} & \multicolumn{3}{|c|}{$\begin{array}{r}\text { MOTHER } \\
\text { RATINGS }\end{array}$} \\
\hline & $\begin{array}{l}\text { MEAN } \\
\text { AGE }\end{array}$ & Sd & $\underline{N}$ & $\begin{array}{l}\text { MEAN } \\
\text { AGE }\end{array}$ & Sd & $\underline{\mathbf{N}}$ & $\begin{array}{l}\text { MEAN } \\
\text { AGE }\end{array}$ & sd & $\underline{\mathbf{N}}$ \\
\hline $\begin{array}{l}\text { Beginning } \\
\text { Early } \\
\text { Mid } \\
\text { Advanced } \\
\text { Post }\end{array}$ & $\begin{array}{l}10.71 \\
11.60 \\
12.10 \\
14.05 \\
14.90\end{array}$ & $\begin{array}{l}(.94) \\
(1.30) \\
(1.35) \\
(1.48) \\
(1.66)\end{array}$ & $\begin{array}{l}66 \\
37 \\
39 \\
44 \\
10\end{array}$ & $\begin{array}{l}10.50 \\
11.43 \\
12.11 \\
13.65 \\
14.77\end{array}$ & $\begin{array}{l}(.71) \\
(1.38) \\
(1.42) \\
(1.96) \\
(1.48)\end{array}$ & $\begin{array}{l}40 \\
37 \\
72 \\
37 \\
13\end{array}$ & $\begin{array}{l}10.96 \\
12.00 \\
13.26 \\
14.24 \\
15.60\end{array}$ & $\begin{array}{l}(1.04) \\
(1.35) \\
(1.54) \\
(1.39) \\
(2.30)\end{array}$ & $\begin{array}{r}102 \\
22 \\
46 \\
25 \\
5\end{array}$ \\
\hline
\end{tabular}

BOYS MAVE 2

\begin{tabular}{|c|c|c|}
\hline \multirow[b]{2}{*}{$\begin{array}{l}\text { PUBERTAL } \\
\text { STAGE }\end{array}$} & \multicolumn{2}{|c|}{$\begin{array}{l}\text { COABINED } \\
\text { RATINGS }\end{array}$} \\
\hline & $\begin{array}{l}\text { MEAN } \\
\text { AGE }\end{array}$ & Sd \\
\hline $\begin{array}{l}\text { Beginning } \\
\text { Early } \\
\text { Mid } \\
\text { Advanced } \\
\text { Post }\end{array}$ & $\begin{array}{l}12.67 \\
13.06 \\
13.24 \\
14.62 \\
16.54\end{array}$ & $\begin{array}{l}(.52) \\
(.97) \\
(1.15) \\
(1.43) \\
(1.43)\end{array}$ \\
\hline
\end{tabular}

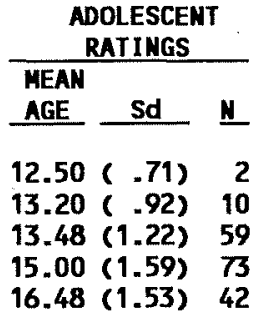

\begin{tabular}{cc}
$\begin{array}{c}\text { MOTHER } \\
\text { RATINGS }\end{array}$ \\
\hline $\begin{array}{ll}\text { MEAN } \\
\text { AGE }\end{array}$ Sd & N \\
\hline $12.87(.64)$ & 15 \\
$13.04(1.00)$ & 24 \\
$13.98(1.36)$ & 56 \\
$15.23(1.38)$ & 65 \\
$16.85(1.39)$ & 39
\end{tabular}

GIRLS WAVE 1

\begin{tabular}{|c|c|c|}
\hline \multirow[b]{2}{*}{$\begin{array}{l}\text { PUBERTAL } \\
\text { STAGE }\end{array}$} & \multicolumn{2}{|r|}{$\begin{array}{l}\text { COMBINED } \\
\text { RATINGS }\end{array}$} \\
\hline & $\begin{array}{l}\text { MEAN } \\
\text { AGE }\end{array}$ & Sd \\
\hline $\begin{array}{l}\text { Beginning } \\
\text { Early } \\
\text { Mid } \\
\text { Advanced } \\
\text { Post }\end{array}$ & $\begin{array}{l}10.30 \\
10.65 \\
11.72 \\
13.63 \\
15.29\end{array}$ & $\begin{array}{l}(.56) \\
(.74) \\
(1.44) \\
(1.36) \\
(1.21)\end{array}$ \\
\hline
\end{tabular}

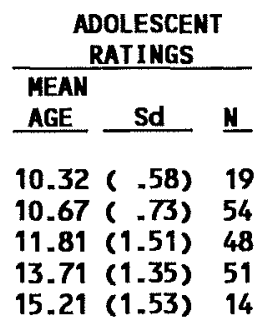

\begin{tabular}{|c|c|c|}
\hline & $\begin{array}{l}\text { THER } \\
\text { INGS }\end{array}$ & \\
\hline $\begin{array}{l}\text { MEAN } \\
\text { AGE }\end{array}$ & Sd & N \\
\hline $\begin{array}{l}10.38 \\
10.62 \\
11.97 \\
13.55 \\
14.79\end{array}$ & $\begin{array}{r}.86) \\
.73) \\
1.30) \\
1.36) \\
1.50)\end{array}$ & $\begin{array}{l}29 \\
55 \\
36 \\
47 \\
24\end{array}$ \\
\hline
\end{tabular}

\section{GIRLS WAVE 2}

\begin{tabular}{|c|c|c|c|}
\hline \multirow[b]{2}{*}{$\begin{array}{l}\text { PUBERTAL } \\
\text { STAGE }\end{array}$} & \multicolumn{3}{|c|}{$\begin{array}{l}\text { COHBINED } \\
\text { RATINGS }\end{array}$} \\
\hline & $\begin{array}{l}\text { MEAN } \\
\text { AGE }\end{array}$ & & $\mathbf{N}$ \\
\hline $\begin{array}{l}\text { Beginning } \\
\text { Early } \\
\text { Mid } \\
\text { Advanced } \\
\text { Post }\end{array}$ & $\begin{array}{c}-- \\
12.14 \\
13.24 \\
14.39 \\
16.37\end{array}$ & $\begin{array}{l}.38) \\
.90) \\
(.51) \\
(.63)\end{array}$ & $\begin{array}{l}46 \\
67 \\
60\end{array}$ \\
\hline
\end{tabular}

\begin{tabular}{llr}
\multicolumn{2}{c}{$\begin{array}{c}\text { ADOLESCENT } \\
\text { RATINGS }\end{array}$} \\
\begin{tabular}{lll} 
MEAN & & \\
AGE & Sd & $N$ \\
\hline & & \\
\hdashline & - & - \\
12.38 & $(.74)$ & 8 \\
13.33 & $(1.17)$ & 45 \\
14.52 & $(1.49)$ & 88 \\
16.61 & $(1.79)$ & 43
\end{tabular}
\end{tabular}

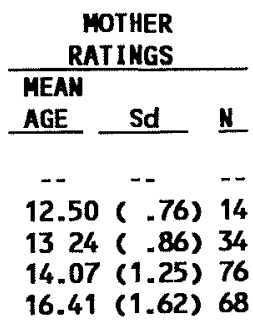


FIGURE 1.

FIGURAL REPRESENTATION OF THE SCORING UTILIZED IN COMPUTING PUBERTAL GRONTH CATEGORIES

BOYS AND GIRLS

Pubertal Stage Scores at Wave 2

$\begin{array}{lllll}1 & 2 & 3 & 4 & 5\end{array}$

\begin{tabular}{|c|c|c|c|c|c|c|}
\hline & 1 & $\begin{array}{l}\text { No } \\
\text { Change }\end{array}$ & $\begin{array}{c}\text { Early- } \\
\text { Mid }\end{array}$ & $\begin{array}{c}\text { Early- } \\
\text { Mid }\end{array}$ & $\begin{array}{c}\text { Early- } \\
\text { Late }\end{array}$ & $\begin{array}{l}\text { No } \\
\text { Subjects }\end{array}$ \\
\hline Pubertal & 2 & & $\begin{array}{l}\text { No } \\
\text { Change }\end{array}$ & $\begin{array}{l}\text { Early- } \\
\text { Mid }\end{array}$ & $\begin{array}{c}\text { Case-by } \\
\text { Case }\end{array}$ & $\begin{array}{l}\text { Mid- } \\
\text { Late }\end{array}$ \\
\hline Stage & 3 & & - & $\begin{array}{l}\text { No } \\
\text { Change }\end{array}$ & $\begin{array}{l}\text { Mid- } \\
\text { Late }\end{array}$ & $\begin{array}{l}\text { Mid- } \\
\text { Late }\end{array}$ \\
\hline Have 1 & 4 & & & & $\begin{array}{l}\text { No } \\
\text { Change }\end{array}$ & $\begin{array}{l}\text { Mid- } \\
\text { Late }\end{array}$ \\
\hline & 5 & & & & & $\begin{array}{l}\text { No } \\
\text { Change }\end{array}$ \\
\hline
\end{tabular}


TABLE 6.

PERCENT OF SUBJECTS CLASSIFIED INTO PUBERTAL GROMTH CATEGORIES.

Pubertal Growth Categories

Combined Adolescents Mothers
Ratings Ratings Ratings

GIRLS

No Change

Early- to Mid-Puberty

Mid- to Late-Puberty

BOYS

No Change

Early- to Mid-Puberty

Mid- to Late-Puberty
$20 \%$

$40 \%$

$20 \%$

40\%

$55 \%$

$25 \%$
$36 \%$

$18 \%$

$46 \%$

$52 \%$

$44 x$

$19 \%$

$29 \%$

$25 \%$ 
Table 7 .

Means and standard Deviations of the Continuous, Curvil inear Pubertal Growth Variable by Pubertal Grouth Groups.

$\frac{\text { GIRLS }}{P}$

Pubertal Change Combined

Category Ratings

Mean (Sd) N

NO CHANGE

$-.59(.66) 64$

EARLY-TO-MID

$1.81(.82) 31$

MID-TO-LATE

$-.86(.92) 62$
Mother

Ratings

Mean (Sd) $N$

$-.27(.53) 52$

$1.95(.70) 38$

$-.84(.13) 99$

Bors

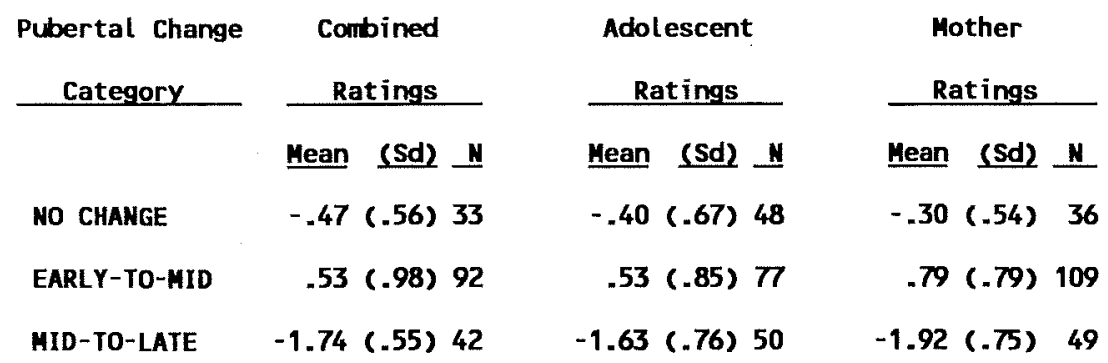


TABLE 8.

AVERAGE AGE IN YEARS OF MENARCHE AS REPORTED BY MOTHERS AND DAUGHTERS

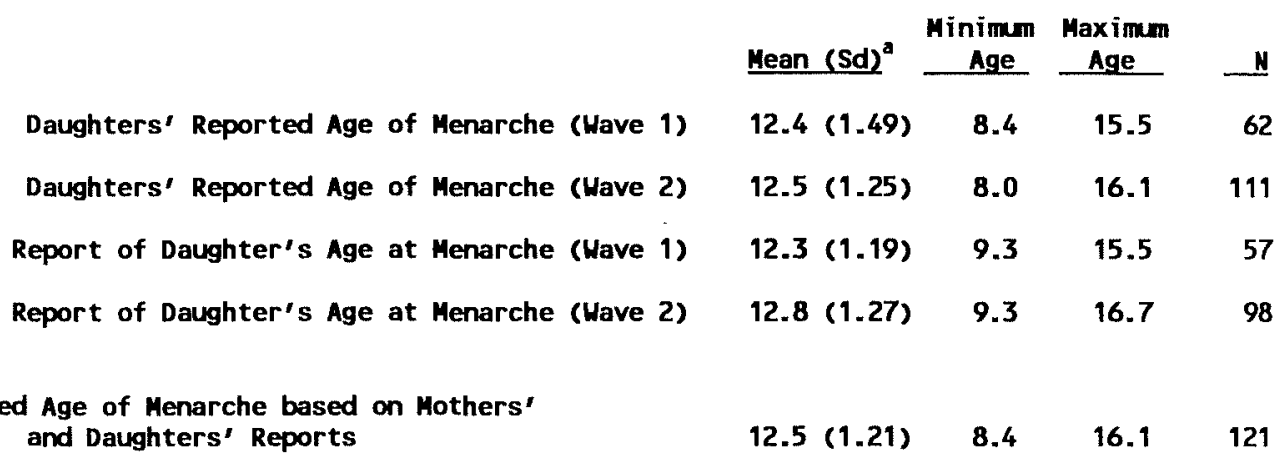

${ }^{a}$ Mean and Standard deviations are computed in years with decimal values indicating a porportion of a year (in tenths) rather than in months. 
TABLE 9.

AGES AT MENARCHE FOR EARLY, ON-TIME AND LATE MATURING GIRLS.

Ages based on Both Daughter's and Mother's Reports

Early Maturers

On-time Maturers

Late Maturers

Ages based on Daughter's Reports

Early Maturers

On-time Maturers

Late Maturers

Ages based on Mother's Reports

Early Maturers

On-time Maturers

Late Maturers
Average

Age (yrs)

Range of

12.4

Ages (yrs) N

8.4-11.9 29

13.9

12.0-13.2 55

$13.3-16.0 \quad 33$
Average Range of

Age (yrs) Ages (yrs) N
11.1
8.4-11.9 29
12.4
12.0-13.2 55
13.9
$13.3-16.0$
33 
TABLE 10.

IHTERRATER CONCORDANCE AND ACROSS-TIME CONCORDANCE FOR TIMING OF PUBERTY (YEAR AMD MONTH): MOTHERS' AHD DAUGHTERS' REPORT OF DAUGHTER'S AGE AT MEMARCHE.

\begin{tabular}{|c|c|c|c|}
\hline Interrater Concordance: Mothers and Daughters & $\begin{array}{c}\text { Percent } \\
\text { Agree } \\
\text { Within } \\
6 \text { Months } \\
\end{array}$ & Corr & $\begin{array}{l}\text { Number of } \\
\text { Dyads }\end{array}$ \\
\hline Agreed Menarche Occurred Before Mave 1 & $75 x$ & $.91 * * *$ & 48 \\
\hline Agreed Menarach Occurred Between Wave 1 and 2 & $62 x$ & $.76 * * *$ & 74 \\
\hline Across-Time Concordance: Have 1 to Mave 2 & $\begin{array}{c}\text { Percent } \\
\text { Agree } \\
\text { Within } \\
6 \text { Months } \\
\end{array}$ & Corr & $\begin{array}{c}\text { Number of } \\
\text { Dyads }\end{array}$ \\
\hline Daughters' Report & $50 \%$ & $.72 * * \star$ & 42 \\
\hline Mothers' Report & $59 \%$ & $.84 * * *$ & 32 \\
\hline
\end{tabular}

NOTE: $*=p<.05 ; \star \star=p<.01 ; \star \star \star=p<.001$ 
Table 11.

Cronbach Alphas for Parenting Variables: Composites. Mother Reports and Child Reports.

\section{Have 1 Have 2}

Composite Variables

Mothers' Parenting

$\begin{array}{lll}\text { Positivity } & .68 & .73 \\ \text { Negativity } & .74 & .80 \\ \text { Control } & .64 & .68\end{array}$

Fathers' Parenting

Positivity

$\begin{array}{ll}.76 & .76\end{array}$

Megativity

$.69 \quad .70$

Control

.59

.69

Mothers' Report

Mothers' Parenting

$\begin{array}{lll}\text { Positivity } & .70 & .73 \\ \text { Negativity } & .75 & .69 \\ \text { Control } & .82 & .85\end{array}$

\section{Child Report}

Mothers' Parenting

$\begin{array}{lll}\text { Positivity } & .67 & .68 \\ \text { Negativity } & .64 & .76 \\ \text { Control } & .91 & .85\end{array}$

Fathers' Parenting

\begin{tabular}{|c|c|c|c|}
\hline Positivity & & .70 & .73 \\
\hline Megativity & $\because$ & .60 & .69 \\
\hline Control & & .92 & .93 \\
\hline
\end{tabular}


Table 12.

Parental Positivity: Interobserver Rel iabi lities, Interobserver Agreement (Observational Measures) and Cronbach ALphas (Questionnaire Measures)

\begin{tabular}{|c|c|c|c|c|c|c|}
\hline \multirow[b]{3}{*}{ Observational Measures } & \multicolumn{3}{|c|}{ Nave 1} & \multicolumn{3}{|c|}{ Mave 2} \\
\hline & \multicolumn{3}{|c|}{ Percent } & \multicolumn{3}{|c|}{ Percent } \\
\hline & $\begin{array}{l}\text { Exact } \\
\text { Agree }\end{array}$ & $\begin{array}{l}\text { Meighted } \\
\text { Kappa } \\
\end{array}$ & $\begin{array}{l}\text { Pearson } \\
\text { Corr } \\
\end{array}$ & $\begin{array}{c}\text { Exact } \\
\text { Agree } \\
\end{array}$ & $\begin{array}{l}\text { Weighted } \\
\text { Kappa }\end{array}$ & $\begin{array}{l}\text { Pearson } \\
\text { Corr } \\
\end{array}$ \\
\hline Warmth/Support & $78 x$ & .72 & .79 & $91 x$ & .59 & .72 \\
\hline Assertiveness & $73 x$ & .66 & .75 & $69 x$ & .56 & .65 \\
\hline Involvement & $86 x$ & .64 & .68 & $91 x$ & .69 & .72 \\
\hline Communication & $77 x$ & .58 & .62 & $88 x$ & .50 & .52 \\
\hline
\end{tabular}

\begin{tabular}{|c|c|c|c|c|c|c|c|c|}
\hline & Cront & zach ALE & phas: $W$ & ave 1 & Cron & bach Al & phas: $U_{i}$ & ave 2 \\
\hline & Child $\mathrm{P}$ & Ratings & Mother & Father & Child & Ratings & Mother & \\
\hline Questionnaire Measures & Mother & Father & Rating & Rating & Mother & Father & Rating & Ra \\
\hline Expression of Affection & .86 & .82 & .81 & .81 & .85 & .88 & .85 & .86 \\
\hline Instrumental Affection & .81 & .80 & .77 & .78 & .82 & .86 & .75 &.$\overline{5}$ \\
\hline Closeness/Affection (PCR) & .89 & .91 & .84 & .83 & .91 & .92 & .85 & .87 \\
\hline
\end{tabular}


Table 13.

Parental Negativity: Interobserver Reliabilities, Interobserver Agreement (Observational Measures) and Cronbach Alphas (Questionnaire Measures)

\begin{tabular}{|c|c|c|c|c|c|c|}
\hline \multirow[b]{2}{*}{ Observational Measures } & \multicolumn{3}{|c|}{ Have 1} & \multicolumn{3}{|c|}{ Have 2} \\
\hline & $\begin{array}{l}\text { Exact } \\
\text { Agree } \\
\end{array}$ & $\begin{array}{l}\text { Percent } \\
\text { Weighted } \\
\text { Kappa } \\
\end{array}$ & $\begin{array}{l}\text { Pearson } \\
\text { Corr }\end{array}$ & $\begin{array}{c}\text { Exact } \\
\text { Agree } \\
\end{array}$ & $\begin{array}{l}\text { Percent } \\
\text { Weighted } \\
\text { Kappa } \\
\end{array}$ & $\begin{array}{c}\text { Pearson } \\
\text { Corr } \\
\end{array}$ \\
\hline Coercion & $75 \%$ & .69 & .78 & $73 x$ & .55 & .64 \\
\hline Transactional Conflict & $80 \%$ & .74 & .79 & $89 x$ & .73 & .81 \\
\hline Anger/Rejection & $76 \%$ & .73 & .81 & $76 \%$ & .63 & .73 \\
\hline
\end{tabular}

Cronbach Alphas: Uave 1

Child Ratings Mother Father

Questionnaire Measures Conflict-Total (PCR) Conflict-Total (CRI-I) Punitive Discipline Symbolic Aggression Mother Father Rating Rating

$\begin{array}{rrrr}.84 & .82 & .87 & .90 \\ .80 & .85 & .74 & .87 \\ .64 & .76 & .79 & .71 \\ .77 & .77 & .77 & .77\end{array}$

Cronbach Alphas: Wave 2

Child Ratings Mother Father Mother Father Rating Rating

$\begin{array}{rrrr}.88 & .85 & .89 & .92 \\ .89 & .92 & .88 & .85 \\ .86 & .87 & .85 & .82 \\ .76 & .81 & .76 & .78\end{array}$


Table 14.

Parental Control: Interobserver Rel iabi L ities, Interobserver Agreement (Observational Measures) and Cronbach Alphas (Questionaire Measures)

\begin{tabular}{|c|c|c|c|c|c|c|}
\hline \multirow[b]{2}{*}{ Observational Measures } & \multicolumn{3}{|c|}{ Wave 1} & \multicolumn{3}{|c|}{ Uave 2} \\
\hline & $\begin{array}{l}\text { Exact } \\
\text { Agree }\end{array}$ & $\begin{array}{l}\text { Percent } \\
\text { Ueighted } \\
\text { Kappa } \\
\end{array}$ & $\begin{array}{c}\text { Pearson } \\
\text { Corr } \\
\end{array}$ & $\begin{array}{l}\text { Exact } \\
\text { Agree }\end{array}$ & $\begin{array}{l}\text { Percent } \\
\text { Weighted } \\
\text { Kappa } \\
\end{array}$ & $\begin{array}{c}\text { Pearson } \\
\text { Corr }\end{array}$ \\
\hline Parental Influence & $70 \%$ & .59 & .68 & $75 x$ & .61 & .71 \\
\hline Authority/Control & $76 \%$ & .59 & .64 & $81 \%$ & .52 & .55 \\
\hline
\end{tabular}

\section{Cronbach Alphas: Mave 1 Cronbach Alphas: Uave 2}

Child Ratings Mother Father Child Ratings Mother Father

Questionnaire Measures Mother Father Rating Rating

$\begin{array}{lllll}\text { Total Attempted Control } & .91 & .91 & .93 & .92\end{array}$

$\begin{array}{lllll}\text { Total Actual Control } & .93 & .94 & .95 & .94\end{array}$
Mother Father Rating Rating

$\begin{array}{llll}.92 & .94 & .92 & .93 \\ .94 & .95 & .93 & .94\end{array}$


Parent-Adolescent Relations and Puberty

Figure 2.

Figural Representation of Negative Curvilinear Relationships between Pubertal Change and Parent ing Behavior as Measured by Difference Scores.

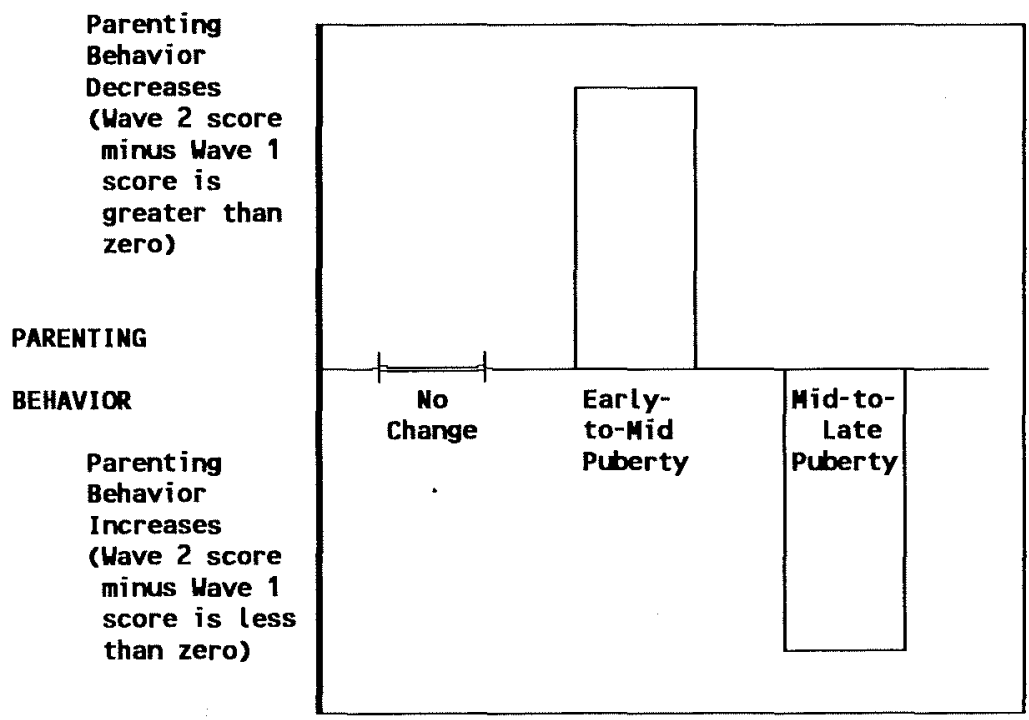


Table 15.

Mothers' Parenting by Composite Scores: Univariate Means and Standard Deviations

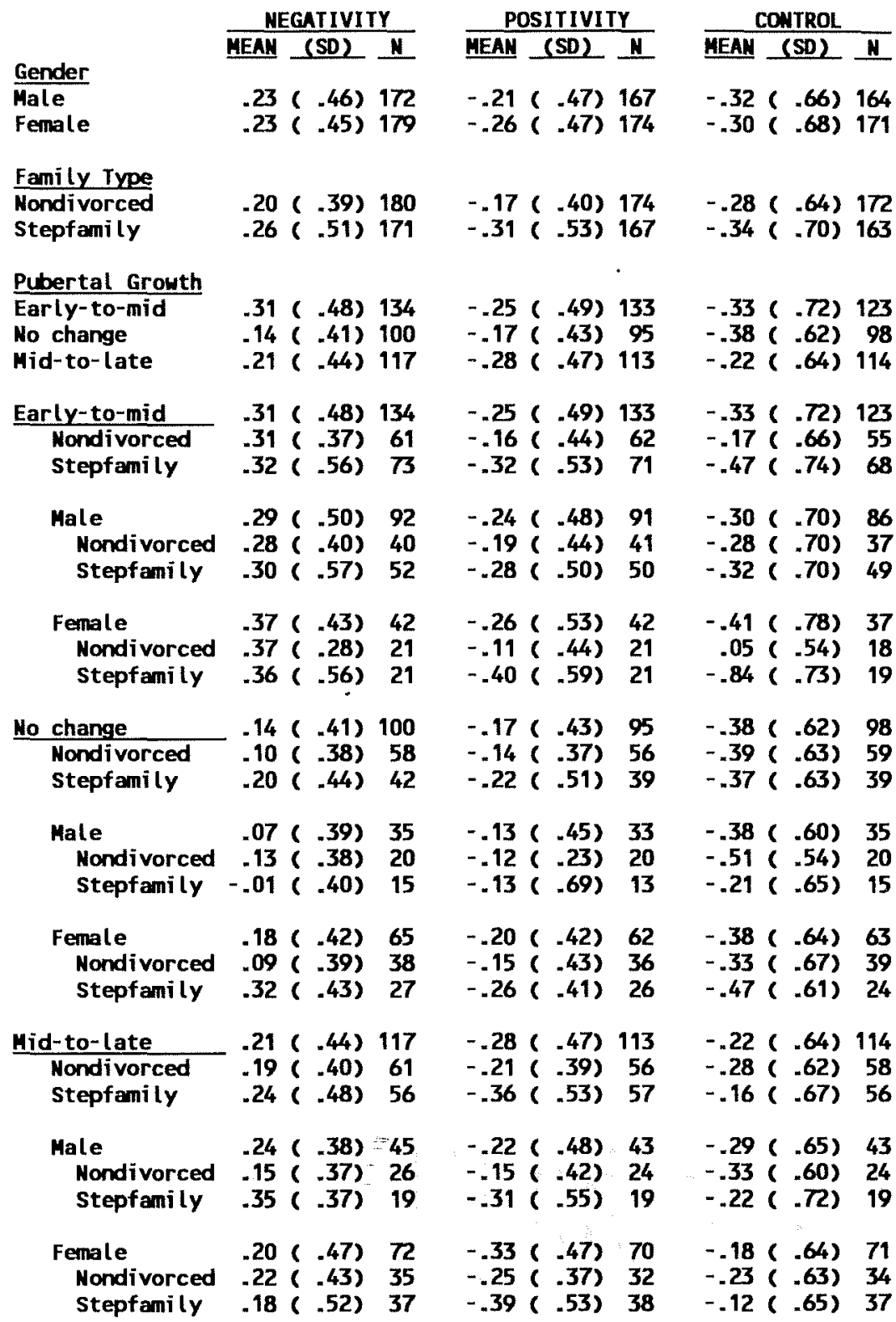


Table 16.

F-Values and Significant Levels for Multivariate Analyses of Mother's Parenting: Difference Scores from Composite Ratings.

\begin{tabular}{|c|c|c|c|c|c|c|c|}
\hline \multirow{2}{*}{ 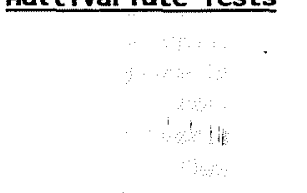 } & \multicolumn{3}{|c|}{ Main Effects } & \multicolumn{4}{|c|}{ Interactions } \\
\hline & $\begin{array}{l}\text { Pubertal } \\
\text { Growth }\end{array}$ & $\begin{array}{l}\text { Child } \\
\text { Sex } \\
\end{array}$ & $\begin{array}{l}\text { Family } \\
\text { Type }\end{array}$ & $\begin{array}{l}\text { Pub.Gru } \\
\text { X Gender } \\
\end{array}$ & $\begin{array}{r}\text { Pub_Gru } \\
\text { X Family } \\
\end{array}$ & $\begin{array}{l}\text { Fanily } x \\
\text { Gender }\end{array}$ & $\begin{array}{r}\text { Fami ly } X \\
\text { Gender } X \\
\text { Pub_Growth }\end{array}$ \\
\hline $\begin{array}{l}\text { Multivariate } F \\
\text { Multivariate } d f\end{array}$ & $\begin{array}{c}2.59 \star \\
(6,604)\end{array}$ & $\begin{array}{c}1.37 \\
(3,301)\end{array}$ & $\begin{array}{l}3.32^{\star} \\
(3,301)\end{array}$ & $\begin{array}{l}.50 \\
(6,604)\end{array}$ & $\begin{array}{c}1.79 \\
(6,604)\end{array}$ & $\begin{array}{c}1.84 \\
(3,301)\end{array}$ & $\begin{array}{c}1.91 \\
(6,604)\end{array}$ \\
\hline $\begin{array}{l}\text { Megativity } F \\
\text { Positivity } F \\
\text { Control F } \\
\text { Univariate df }\end{array}$ & $\begin{array}{l}4.45^{\star} \\
1.63 \\
2.20 \\
(2,303)\end{array}$ & $\begin{array}{c}1.56 \\
3.21 \\
.01 \\
(1,303)\end{array}$ & $\begin{array}{l}-66 \\
9.12^{\star \star} \\
1.60 \\
(1,303)\end{array}$ & $\begin{array}{c}-96 \\
-05 \\
-47 \\
(2,303)\end{array}$ & $\begin{array}{c}-13 \\
1.27 \\
4.30^{\star} \\
(2,303)\end{array}$ & $\begin{array}{c}.25 \\
.94 \\
4.98 \\
(1,303)\end{array}$ & $\begin{array}{c}3.20 \\
.57 \\
2.31 \\
(2,303)\end{array}$ \\
\hline Univariate Findings $^{\text {a }}$ & $\begin{array}{l}\text { Pubertal } \\
\text { Growth }^{\mathbf{b}}\end{array}$ & $\begin{array}{l}\text { Child } \\
\text { Sex }\end{array}$ & $\begin{array}{l}\text { Family } \\
\text { Type } \\
\end{array}$ & $\begin{array}{l}\text { Pub.Gru } \\
\text { X Gender }\end{array}$ & $\begin{array}{l}\text { Pub_Gru } \\
\text { X Fanily }\end{array}$ & $\begin{array}{l}\text { Fami ly X } \\
\text { Gender }\end{array}$ & $\begin{array}{l}\text { Fani ly X } \\
\text { Gender X } \\
\text { Pub_Growth } \\
\end{array}$ \\
\hline Megativity & $\begin{array}{l}\text { Early-Mid } \\
>\text { Mo Chng }\end{array}$ & - & - & - & - & - & - \\
\hline Positivity & n.s. & - & $\begin{array}{l}\text { Step > } \\
\text { Nondiv }\end{array}$ & - & - & - & - \\
\hline Control & n.s. & - & - & - & $\begin{array}{c}\text { [Early-Mid: } \\
\text { Step > } \\
\text { Mondiv] }\end{array}$ & - & - \\
\hline
\end{tabular}


Parent-Adolescent Relations and Puberty

Table 16 (Cont inued).

F-Values and Significant Levels for Multivariate Analyses of Mother's Parenting: Difference Scores from Composite Ratings.

Note: Multivariate test is Pillais.

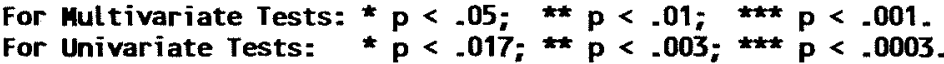

Square brackets denote univariate results from the multivariate analyses which had no corresponding multivariate significant effect or interaction.

Univariate tests are follow-up tests based on multivariate results.

These results were based on the univariate sample.

bubertal Growth Group differences are post hoc tests.

Abbreviations

Family Type: Step = Stepfamily

Mondiv = Nondivorced families

Pubertal Growth Groups: Early-Mid = Early-to-Mid Pubertal Growth Group

No Chng $=$ No Change Pubertal Grouth Group
Mid-Late = Mid-to-Late Pubertal Growth Grow

Maves: $\mathrm{H1}=$ Mave 1 
Table 17.

Fathers' Parenting by Difference Scores (Composite Ratings): Univariate Means and Standard Deviations.

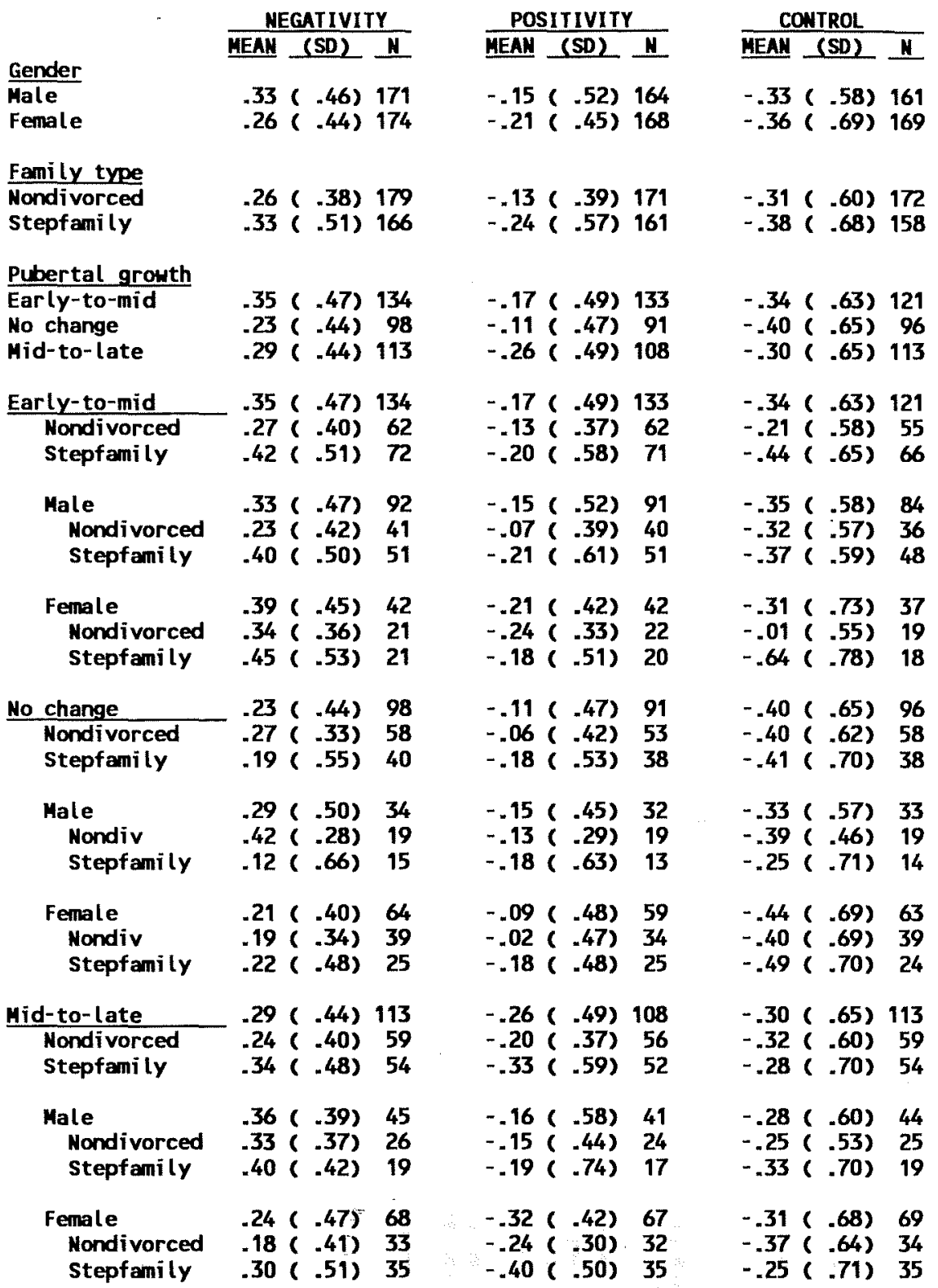


Parent-Adolescent Relations and Puberty

Table 18

F-Values and Significant Levels for Multivariate Analyses of Fathers' Parenting (Family Iype Analyses): Difference Scores from Composite Ratings

\begin{tabular}{|c|c|c|c|c|c|c|c|}
\hline \multirow{2}{*}{ Multivariate Tests } & \multicolumn{3}{|c|}{ Main Effects } & \multicolumn{4}{|c|}{ Interactions } \\
\hline & $\begin{array}{l}\text { Pubertal } \\
\text { Growth }\end{array}$ & $\begin{array}{l}\text { Child } \\
\text { Sex } \\
\end{array}$ & $\begin{array}{l}\text { Fanily } \\
\text { Iype }\end{array}$ & $\begin{array}{r}\text { Pub_Gru } \\
\times \text { Gender } \\
\end{array}$ & $\begin{array}{r}\text { Pub_Gru } \\
\text { X Family } \\
\end{array}$ & $\begin{array}{l}\text { Famil } y \mathbf{X} \\
\text { Gender }\end{array}$ & $\begin{array}{l}\text { Family X } \\
\text { Gender X } \\
\text { Pub_Grouth } \\
\end{array}$ \\
\hline $\begin{array}{l}\text { Multivariate } F \\
\text { Multivariate df }\end{array}$ & $\begin{array}{c}1.15 \\
(6,582)\end{array}$ & $\begin{array}{c}-.78 \\
(3,290)\end{array}$ & $\begin{array}{c}1.95 \\
(3,290)\end{array}$ & $\begin{array}{c}1.26 \\
(6,582)\end{array}$ & $\begin{array}{c}1.67 \\
(6,582)\end{array}$ & $\begin{array}{c}-88 \\
(3,290)\end{array}$ & $\begin{array}{c}1.26 \\
(6,582)\end{array}$ \\
\hline $\begin{array}{l}\text { Megativity } F \\
\text { Positivity } F \\
\text { Control F } \\
\text { Univariate df }\end{array}$ & $\begin{array}{c}1.87 \\
.77 \\
-65 \\
(2,292)\end{array}$ & $\begin{array}{c}.38 \\
1.80 \\
.31 \\
(1,292)\end{array}$ & $\begin{array}{c}-84 \\
3.56 \\
2.37 \\
(1.292)\end{array}$ & $\begin{array}{c}1.91 \\
1.16 \\
-48 \\
(2,292)\end{array}$ & $\begin{array}{c}2.58 \\
-06 \\
2.21 \\
(2.292)\end{array}$ & $\begin{array}{c}.52 \\
.03 \\
2.13 \\
(1,292)\end{array}$ & $\begin{array}{c}.59 \\
-48 \\
2.42 \\
(2,292)\end{array}$ \\
\hline Univariate Findings $^{\mathbf{a}}$ & $\begin{array}{l}\text { Pubertal } \\
\text { Growth }^{\mathbf{b}} \\
\end{array}$ & $\begin{array}{l}\text { Child } \\
\text { Sex }\end{array}$ & $\begin{array}{l}\text { Family } \\
\text { Iype }\end{array}$ & $\begin{array}{l}\text { Pub_Gru } \\
\text { X Gender }\end{array}$ & $\begin{array}{l}\text { Pub.Gru } \\
\text { X Family }\end{array}$ & $\begin{array}{l}\text { Family } x \\
\text { Gender }\end{array}$ & $\begin{array}{l}\text { Fami ly } x \\
\text { Gender } x \\
\text { Pub_Grouth }\end{array}$ \\
\hline Negativity & n.s. & - & - & - & - & - & - \\
\hline Positivity & n.s. & - & - & - & - & - & - \\
\hline Control & n.s. & - & - & - & - & - & - \\
\hline
\end{tabular}


Table 18 (cont inued).

F-Values and Significant Levels for Multivariate Analyses of Fathers' Parenting (Family Type Analyses): Difference Scores fron

Composite Ratings

Mote: Multivariate test is Pillais.

For Multivariate Tests: $* p<.05 ; * p<.01 ; \# p<.001$.

For Univariate Tests: $* p<.017 ; \star \star p<.003 ; \star \star \star p<.0003$

anivariate tests are follow-up tests based on multivariate results.

These results were based on the univariate sample.

Dubertal Growth Group differences are post hoc tests.

Abbreviations

Fanily Type: Step = Stepfamily

Mondiv = Mondivorced families

Pubertal Growth Groups: Early-Mid = Early-to-Mid Pubertal Growth Group

No Chng = No Change Pubertal Growth Group

Waves: $\mathrm{M1}=$ Wave 1

Mid-Late $=$ Mid-to-Late Pubertal Growth Group

M2 = Mave 2 
Table 19.

Mothers' Parenting by Composite Scores Mave 1 and Mave 2: Repeated Measures

Univariate Means and Standard Deviations

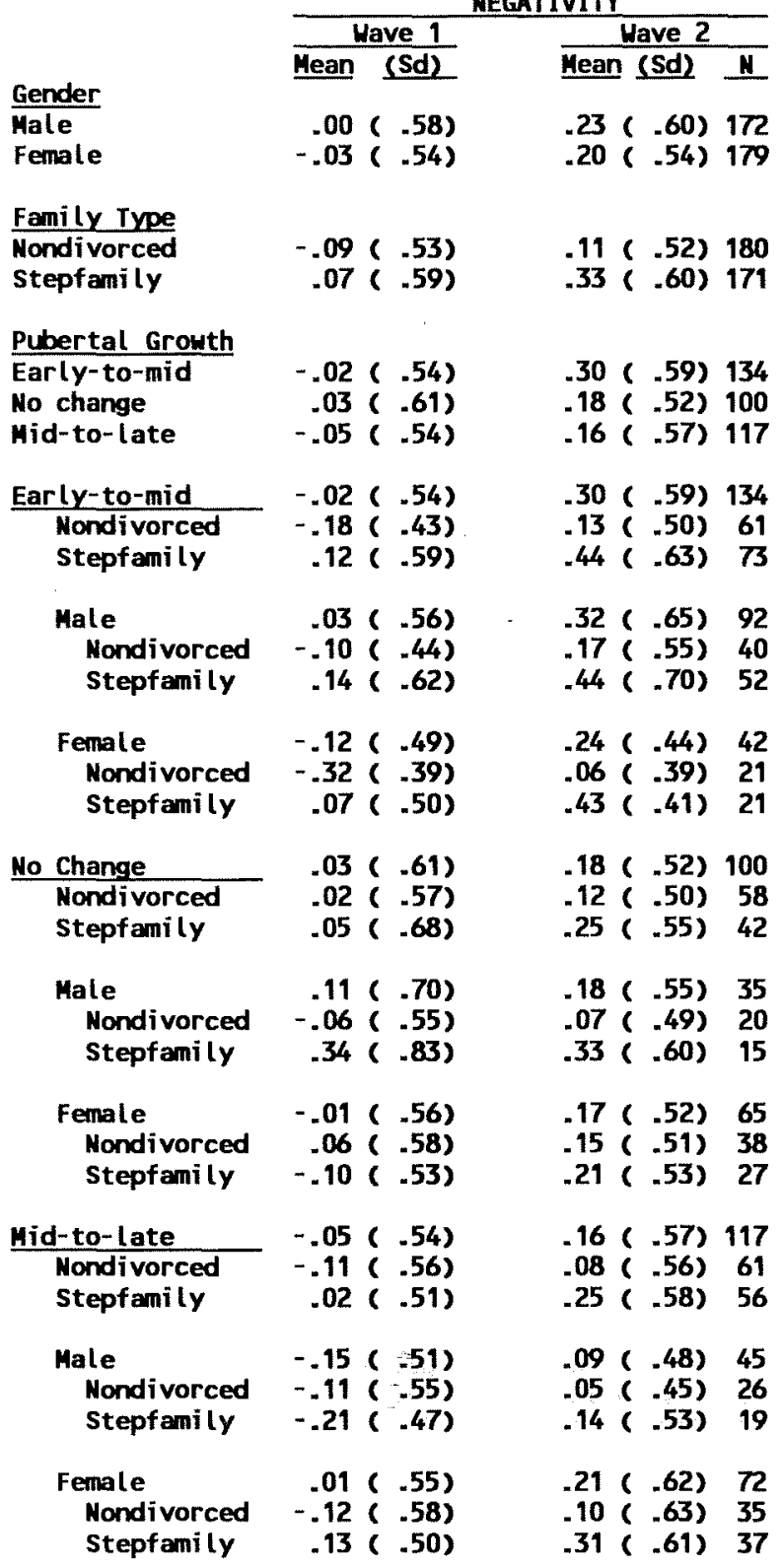


Table 19 (cont inued)

Mothers' Parenting by Composite Scores Wave 1 and Wave 2: Repeated Measures Univariate Means and Standard Deviations

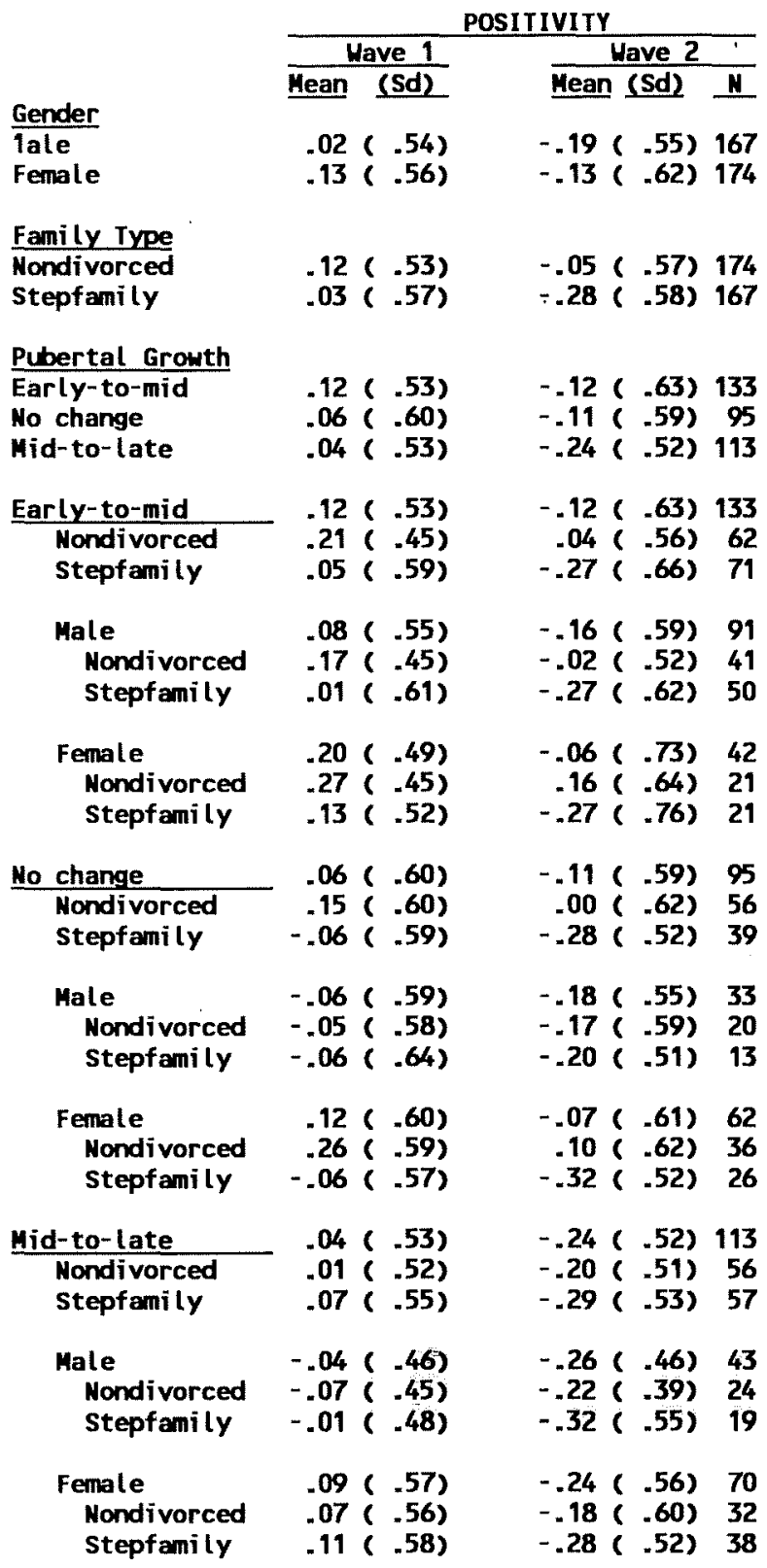


Table 19 (continued)

Mothers' Parenting by Composite Scores Have 1 and Wave 2: Repeated Measures

Univariate Means and Standard Deviations

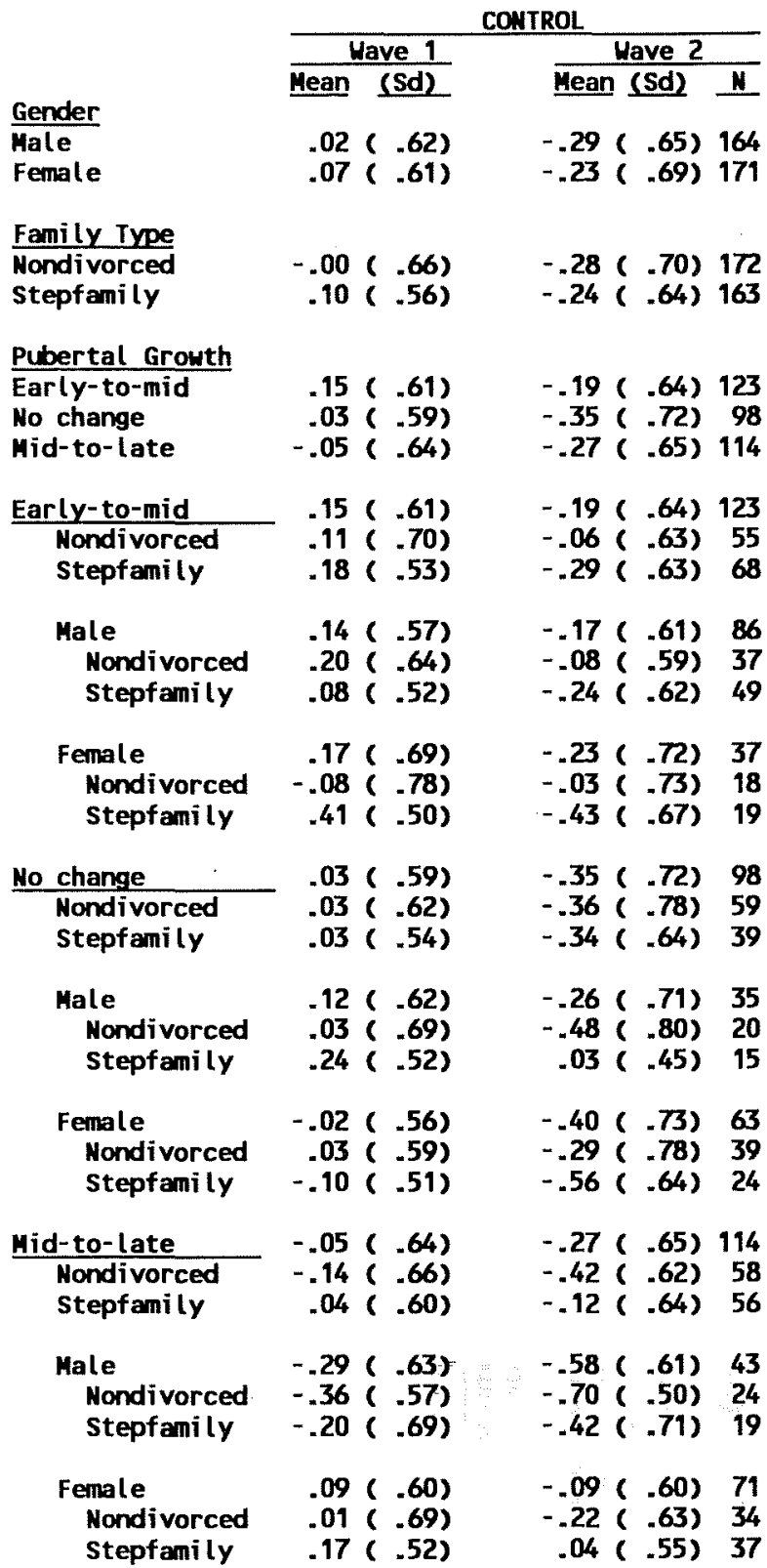


Table 20.

F-Values and Significant Levels for Multivariate Analyses of Mother's Parenting: Repeated Measures from Composite Ratings

\begin{tabular}{|c|c|c|c|c|c|c|c|}
\hline \multirow{2}{*}{ Liviva } & \multicolumn{3}{|c|}{ Main Effects } & \multicolumn{3}{|c|}{ Interactions } & \multirow{3}{*}{$\begin{array}{l}\text { Family X } \\
\text { Gender X } \\
\text { Pub_Growth }\end{array}$} \\
\hline & $\begin{array}{l}\text { Pubertal } \\
\text { Growth }\end{array}$ & $\begin{array}{l}\text { Child } \\
\text { Sex }\end{array}$ & $\begin{array}{l}\text { Family } \\
\text { Iype }\end{array}$ & $\begin{array}{l}\text { Pub_Gru } \\
\text { X Gender }\end{array}$ & $\begin{array}{l}\text { Pub.Gru } \\
\text { X Fanily }\end{array}$ & $\begin{array}{l}\text { Fani ly } X \\
\text { Gender }\end{array}$ & \\
\hline$\therefore \quad H_{i}$ & & & & & & & \\
\hline $\begin{array}{l}\text { Multivariate } F \\
\text { Mult tivariate } d f\end{array}$ & $\begin{array}{c}1.65 \\
(6,604)\end{array}$ & $\begin{array}{c}.68 \\
(3,301)\end{array}$ & $\begin{array}{l}6.84 * * * \\
(3,301)\end{array}$ & $\begin{array}{r}3.25 * t \\
(6,604)\end{array}$ & $\begin{array}{c}1.15 \\
(6,604)\end{array}$ & $(3,301)$ & $\begin{array}{c}1.96 \\
(6,604)\end{array}$ \\
\hline $\begin{array}{l}\text { Negativity } F \\
\text { Positivity F } \\
\text { Control F } \\
\text { Univariate df }\end{array}$ & $\begin{array}{l}1.06 \\
1.21 \\
3.80 \\
(2.303)\end{array}$ & $\begin{array}{c}.10 \\
1.86 \\
.74 \\
(1.303)\end{array}$ & $\begin{array}{l}9.93^{\star \star} \\
9.07^{\star \star} \\
1.91 \\
(1.303)\end{array}$ & $\begin{array}{c}2.11 \\
.08 \\
7.51 \neq \\
(2,303)\end{array}$ & $\begin{array}{c}1.05 \\
1.65 \\
1.76 \\
(2,303)\end{array}$ & $\begin{array}{c}.09 \\
1.20 \\
.97 \\
(1,303)\end{array}$ & $\begin{array}{c}2.55 \\
.68 \\
3.53 \\
(2,303)\end{array}$ \\
\hline Univariate Findings ${ }^{a}$ & $\begin{array}{l}\text { Pubertal } \\
\text { Growth }^{\text {b }} \\
\end{array}$ & $\begin{array}{l}\text { Child } \\
\text { Sex } \\
\end{array}$ & $\begin{array}{l}\text { Family } \\
\text { Iype }\end{array}$ & $\begin{array}{l}\text { Pub.Grw } \\
\text { X Gender }\end{array}$ & $\begin{array}{l}\text { Pub.Gru } \\
\text { X Family }\end{array}$ & $\begin{array}{l}\text { Fani ly } x \\
\text { Gender }\end{array}$ & $\begin{array}{l}\text { Fanily } X \\
\text { Gender } X \\
\text { Pub_Growth }\end{array}$ \\
\hline Negativity & n.s. & - & $\begin{array}{l}\text { Step > } \\
\text { Nondiv }\end{array}$ & - & - & - & - \\
\hline Positivity & n.s. & - & $\begin{array}{l}\text { Mondiv } \\
>\text { Step }\end{array}$ & - & - & - & - \\
\hline Control & n.s. & - & - & $\begin{array}{l}\text { Mid-Late: } \\
\text { Girls > Boy }\end{array}$ & - & - & - \\
\hline
\end{tabular}


Parent-Adolescent Relations and Puberty

124

Table 20 (continued).

F-Values and Significant Levels for Multivariate Analyses of Mother's Parenting: Repeated Measures from Composite Ratings

\begin{tabular}{|c|c|c|c|c|c|c|c|c|}
\hline \multirow[b]{2}{*}{ Multivariate Tests } & \multirow[b]{2}{*}{$\begin{array}{l}\text { Main } \\
\text { Effect } \\
\text { for } \\
\text { Uave } \\
\end{array}$} & \multicolumn{6}{|c|}{ Interactions with Wave Effects } & \multirow[b]{2}{*}{$\begin{array}{l}\text { Family } x \\
\text { Uave } x \\
\text { Gender } x \\
\text { Pub_Growth }\end{array}$} \\
\hline & & $\begin{array}{c}\text { Mave X } \\
\text { Pubertal } \\
\text { Growth } \\
\end{array}$ & $\begin{array}{r}\text { Uave } x \\
\text { Child } \\
\text { Sex } \\
\end{array}$ & $\begin{array}{l}\text { Uave } x \\
\text { Family } \\
\text { Type }\end{array}$ & $\begin{array}{l}\text { Uave X } \\
\text { Pub.Grm } \\
X \text { Gender }\end{array}$ & $\begin{array}{l}\text { Wave X } \\
\text { Pub.Gru } \\
\text { X Family } \\
\end{array}$ & $\begin{array}{l}\text { Wave } X \\
\text { Fanily } x \\
\text { Gender } \\
\end{array}$ & \\
\hline $\begin{array}{l}\text { Multivariate } F \\
\text { Multivariate } d f\end{array}$ & $\begin{array}{l}57.30^{\star * *} \\
(3,301)\end{array}$ & $\begin{array}{c}2.59 * \\
(6,604)\end{array}$ & $\begin{array}{l}1.37 \\
(3,301)\end{array}$ & $\begin{array}{c}3.31 * \\
(3,301)\end{array}$ & $\begin{array}{c}-50 \\
(6,604)\end{array}$ & $\begin{array}{c}1.79 \\
(6,604)\end{array}$ & $\begin{array}{c}1.84 \\
(3,301)\end{array}$ & $\begin{array}{c}1.91 \\
(6,604)\end{array}$ \\
\hline $\begin{array}{ll}\text { Negativity } & F \\
\text { Positivity } & F \\
\text { Control } & F \\
\text { Univariate } & \text { df }\end{array}$ & $\begin{array}{l}69.10^{\star * *} \\
74.13^{* * *} \\
70.25^{\star * t} \\
(1,303)\end{array}$ & $\begin{array}{l}4.45^{\star} \\
1.63 \\
2.20 \\
(2,303)\end{array}$ & $\begin{array}{c}1.57 \\
3.21 \\
.01 \\
(1,303)\end{array}$ & $\begin{array}{l}.66 \\
9.18^{\star \star} \\
1.60 \\
(1,303)\end{array}$ & $\begin{array}{c}.96 \\
.05 \\
-47 \\
(2,303)\end{array}$ & $\begin{array}{c}.13 \\
1.27 \\
4.30^{\star} \\
(2,303)\end{array}$ & $\begin{array}{c}.25 \\
.94 \\
4.98 \\
(1,303)\end{array}$ & $\begin{array}{c}3.20 \\
.57 \\
2.31 \\
(2,303)\end{array}$ \\
\hline Univariate Findings & $\begin{array}{l}\text { Main } \\
\text { Effect } \\
\text { for } \\
\text { Uave } \\
\end{array}$ & $\begin{array}{c}\text { Uave } X \\
\text { Pubertal } \\
\text { Growth } \\
\end{array}$ & $\begin{array}{c}\text { Wave } x \\
\text { Child } \\
\text { Sex } \\
\end{array}$ & $\begin{array}{l}\text { Uave } X \\
\text { Fami ly } \\
\text { Type } \\
\end{array}$ & $\begin{array}{l}\text { Wave X } \\
\text { Pub.Gru } \\
X \text { Gender } \\
\end{array}$ & $\begin{array}{l}\text { Wave } X \\
\text { Pub.Gru } \\
\text { X Family } \\
\end{array}$ & $\begin{array}{l}\text { Wave X } \\
\text { Family X } \\
\text { Gender }\end{array}$ & $\begin{array}{l}\text { Family } X \\
\text { Uave } X \\
\text { Gender X } \\
\text { Pub_Growth } \\
\end{array}$ \\
\hline Negativity & U2 > 41 & $\begin{array}{l}\text { U2: } \\
\text { Early-Mid } \\
<\text { No Chng }\end{array}$ & - & - & - & - & - & - \\
\hline Positivity & W1 > W2 & - & - & $\begin{array}{l}\text { W2:Nondiv } \\
\text { > Step }\end{array}$ & $\checkmark$ & - & - & - \\
\hline Control & U1 > U2 & - & - & - & 1 & $\begin{array}{l}\text { [Early-Mid } \\
\text { IR: } \\
\text { Mondiv> } \\
>\text { Step] }\end{array}$ & - & - \\
\hline
\end{tabular}


Table 20 (continued).

F-Values and Significant Levels for Multivariate Analyses of Mother's Parenting: Repeated Measures from Composite Ratings

Note: Multivariate test is Pillais.

For Multivariate Tests: $\neq p<.05 ; * * p<.01 ; * \star p<.001$.

For Univariate Tests: $\star p<.017 ; \star p * p<.003 ; \star \star \star p<-0003$.

Square brackets denote univariate results from the multivariate analyses wich had no

corresponding multivariate significant effect or interaction.

Univariate tests are follow-up tests based on multivariate results.

These results were based on the univariate sample.

bubertal Growth Group differences are post hoc tests.

Abbreviations

Family Type: Step = Stepfamily

Mondiv = Nondivorced families

Pubertal Growth Groups: Early-Mid = Early-to-Mid Pubertal Growth Group

Mo Chng = Mo Change Pubertal Growth Grow

Uaves: $\mathrm{U1}=$ Have 1

Mid-Late $=$ Mid-to-Late Pubertal Growth Group

$$
\text { WR = Mave } 2
$$


Table 21.

Fathers' Parenting by Composite Ratings Wave 1 and Nave 2 (Repeated Measures)

Univariate Means and Standard Deviations

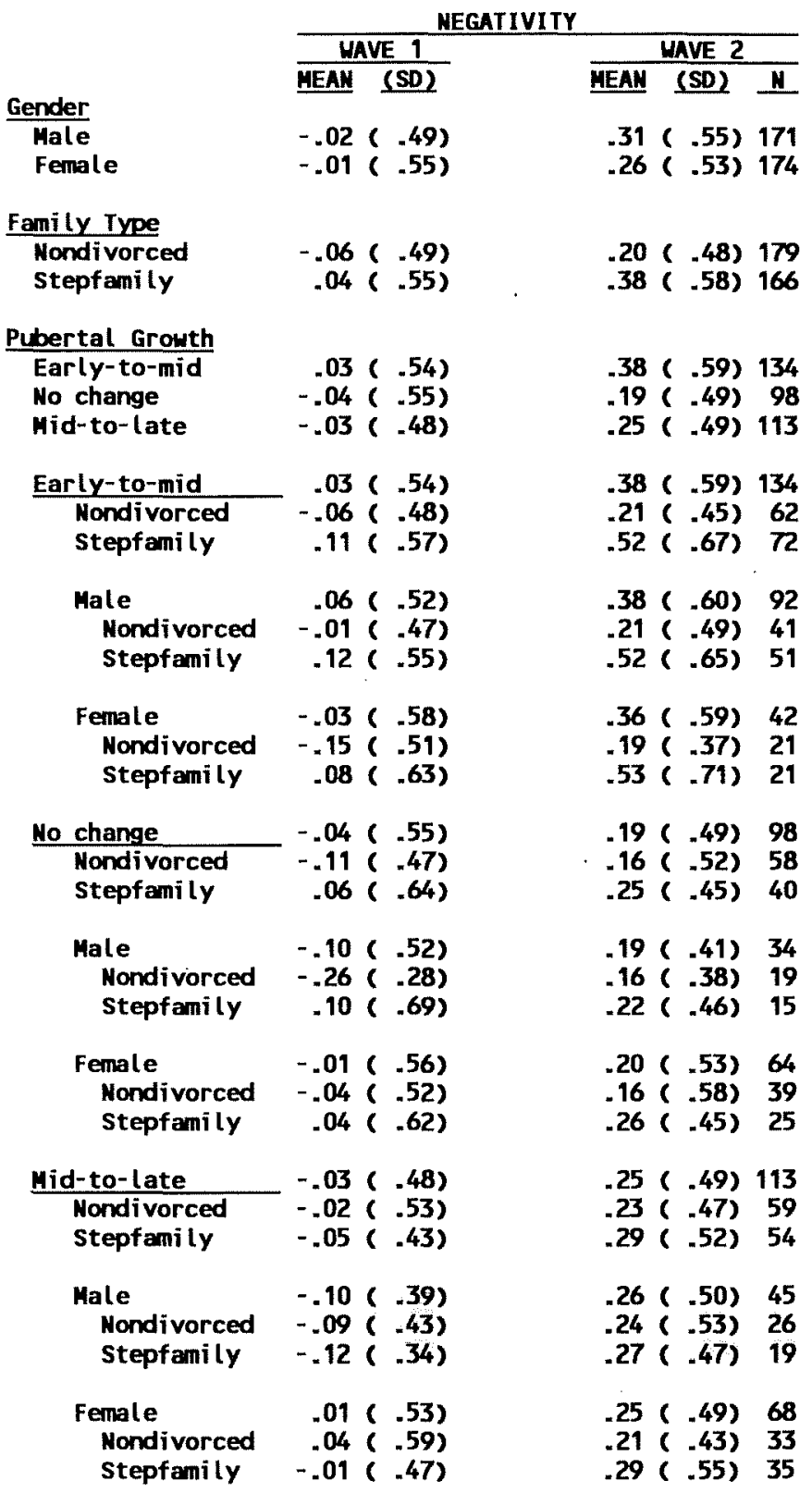


Table 21 (continued).

Fathers' Parenting by Composite Ratings Mave 1 and Wave 2 (Repeated Measures) Univariate Means and Standard Deviations

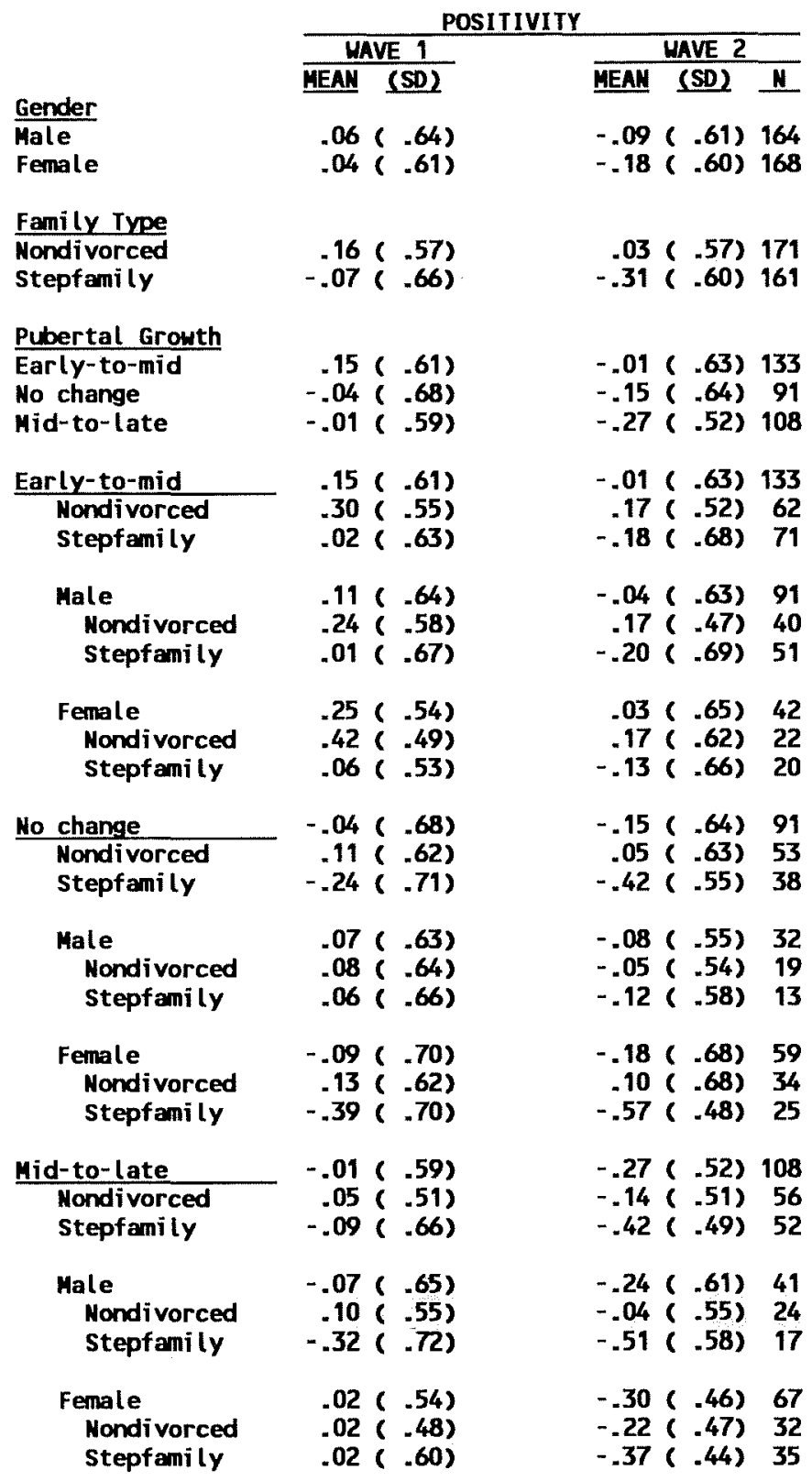


Table 21 (continued).

Fathers' Parenting by Composite Ratings Wave 1 and Wave 2 (Repeated Measures) Univariate Means and Standard Deviations

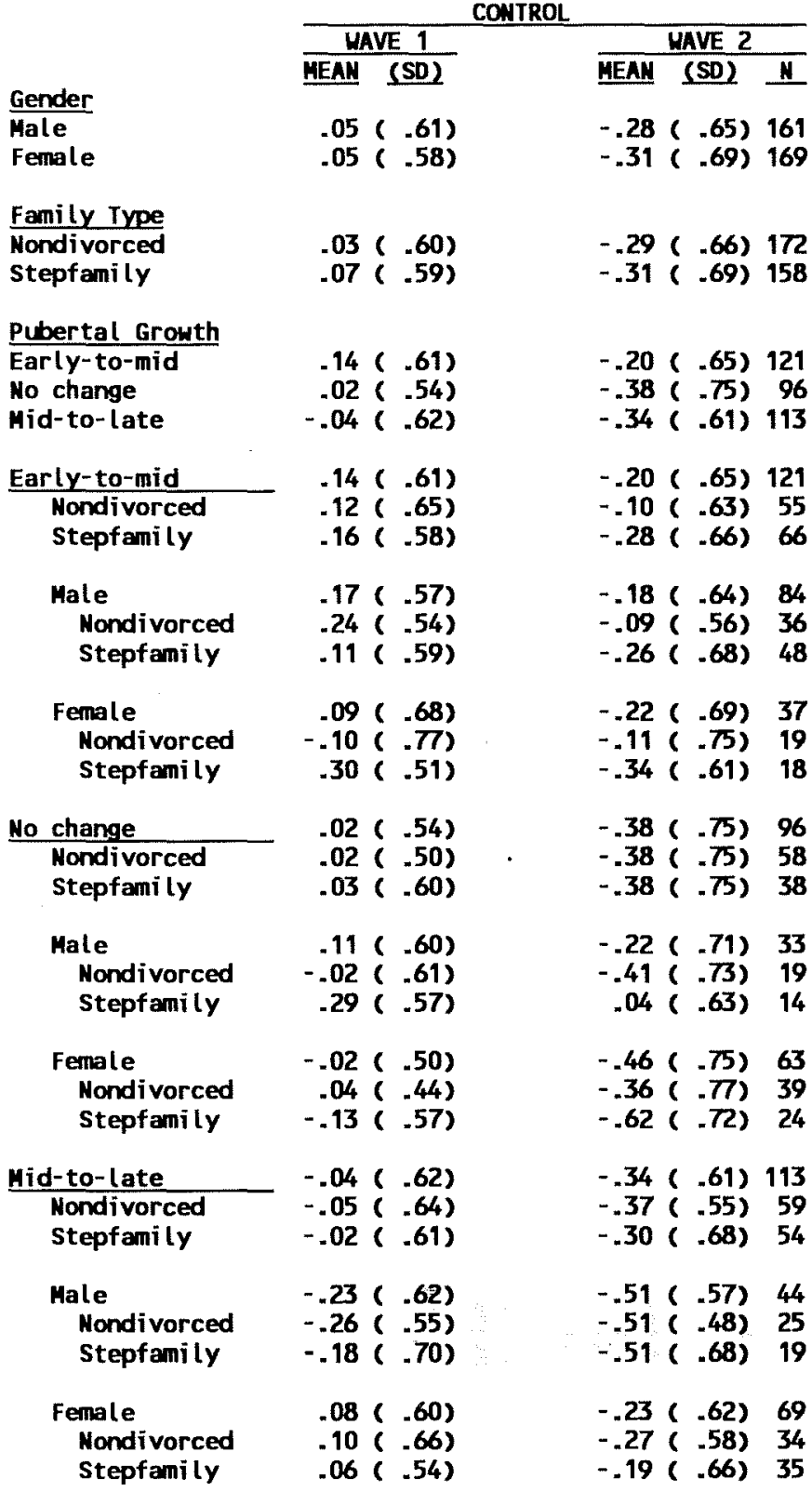


Table 22.

F-Values and Significant Levels for Multivariate Analyses of Fathers' Parenting (Family Iype Analyses): Repeated Measures from Composite Ratings

\begin{tabular}{|c|c|c|c|c|c|c|c|}
\hline \multirow[t]{2}{*}{ Multivariate Tests } & \multicolumn{3}{|c|}{ Main Effects } & \multicolumn{4}{|c|}{ Interactions } \\
\hline & $\begin{array}{l}\text { Pubertal } \\
\text { Grouth }\end{array}$ & $\begin{array}{l}\text { Child } \\
\text { Sex }\end{array}$ & $\begin{array}{l}\text { Fami ly } \\
\text { Iype }\end{array}$ & $\begin{array}{r}\text { Pub_Gru } \\
\mathrm{X} \text { Gender } \\
\end{array}$ & $\begin{array}{r}\text { Pub.Gru } \\
\text { X Family } \\
\end{array}$ & $\begin{array}{l}\text { Fani ly } x \\
\text { Gender } \\
\end{array}$ & $\begin{array}{c}\text { Fani ly X } \\
X \quad \text { Gender X } \\
\text { Pub_Growth }\end{array}$ \\
\hline $\begin{array}{l}\text { Multivariate } F \\
\text { Multivariate } d f\end{array}$ & $\begin{array}{c}2.21 * \\
(6,582)\end{array}$ & $\begin{array}{c}-09 \\
(3,290)\end{array}$ & $\begin{array}{l}10.91 \text { ** } \\
(3,290)\end{array}$ & $\begin{array}{r}3.21 * \star \\
(6,582)\end{array}$ & $\begin{array}{c}-63 \\
(6,582)\end{array}$ & $\begin{array}{c}-74 \\
(3,290)\end{array}$ & $\begin{array}{l}2.77 \\
(6,582)\end{array}$ \\
\hline $\begin{array}{l}\text { Megativity } F \\
\text { Positivity } F \\
\text { Control F } \\
\text { Univariate df }\end{array}$ & $\begin{array}{c}.79 \\
4.45^{\star} \\
4.26^{*} \\
(2.292)\end{array}$ & $\begin{array}{c}-10 \\
-00 \\
-11 \\
(1,292)\end{array}$ & $\begin{array}{c}5.74^{\star} \\
23.82^{\star \star \star} \\
-00 \\
(1,292)\end{array}$ & $\begin{array}{l}.25 \\
1.88 \\
8.03^{\star \star \star \star} \\
(2.292)\end{array}$ & $\begin{array}{c}1.55 \\
-24 \\
-15 \\
(2.292)\end{array}$ & $\begin{array}{c}-33 \\
-58 \\
2.05 \\
(1,292)\end{array}$ & $\begin{array}{c}-41 \\
4.24^{\star} \\
5.81^{\star \star} \\
(2,292)\end{array}$ \\
\hline Univariate Findings $^{a}$ & $\begin{array}{l}\text { Pubertal } \\
\text { Growth }^{b}\end{array}$ & $\begin{array}{l}\text { Child } \\
\text { Sex } \\
\end{array}$ & $\begin{array}{l}\text { Family } \\
\text { Type }\end{array}$ & $\begin{array}{l}\text { Pub_Gru } \\
X \text { Gender }\end{array}$ & $\begin{array}{l}\text { Pub.Gru } \\
\text { X Family }\end{array}$ & $\begin{array}{l}\text { Family } x \\
\text { Gender }\end{array}$ & $\begin{array}{l}\text { Fanily } x \\
\text { Gender } x \\
\text { Pub.Growth }\end{array}$ \\
\hline Megativity & n.s. & - & $\begin{array}{l}\text { Step > } \\
\text { Mondiv }\end{array}$ & - & - & - & - \\
\hline Positivity & $\begin{array}{l}\text { Early-Mid } \\
>\text { Mid-Lat }\end{array}$ & de - & $\begin{array}{l}\text { Mondiv } \\
>\text { Step }\end{array}$ & - & - & - & [See text] \\
\hline Control & $\begin{array}{l}\text { Mo Chng > } \\
\text { Mid-Late }\end{array}$ & - & - & $\begin{array}{l}\text { Mid-Late: } \\
\text { Girls >Boy }\end{array}$ & s & r & $\begin{array}{l}\text { Males(Mondiv): } \\
\text { Early-Mid } \\
\text { > Mid-Late }\end{array}$ \\
\hline
\end{tabular}


Table 22 (cont inued).

F-Values and Significant Levels for Multivariate Analyses of Fathers' Parenting (Family Iype Analyses): Repeated Measures from Composite Ratings

\begin{tabular}{|c|c|c|c|c|c|c|c|c|}
\hline \multirow[b]{2}{*}{ Multivariate Tests } & \multirow[b]{2}{*}{$\begin{array}{l}\text { Main } \\
\text { Effect } \\
\text { for } \\
\text { Uave } \\
\end{array}$} & \multicolumn{6}{|c|}{ Interactions with Wave Effects } & \multirow[b]{2}{*}{$\begin{array}{l}\text { Family } X \\
\text { Uave } X \\
\text { Gender } X \\
\text { Pub.Grouth } \\
\end{array}$} \\
\hline & & $\begin{array}{l}\text { Uave X } \\
\text { Pubertal } \\
\text { Growth }\end{array}$ & $\begin{array}{r}\text { Wave X } \\
\text { Child } \\
\text { Sex } \\
\end{array}$ & $\begin{array}{l}\text { Have } X \\
\text { Fami ly } \\
\text { Iype } \\
\end{array}$ & $\begin{array}{l}\text { Wave X } \\
\text { Pub_Gru } \\
\text { X Gender }\end{array}$ & $\begin{array}{l}\text { Wave X } \\
\text { Pub_Gru } \\
\text { X Fanily }\end{array}$ & $\begin{array}{l}\text { Wave X } \\
\text { Family X } \\
\text { Gender }\end{array}$ & \\
\hline $\begin{array}{l}\text { Multivariate } F \\
\text { Multivariate df }\end{array}$ & $\begin{array}{l}72.55^{\star \star \star *} \\
(3,290)\end{array}$ & $\begin{array}{c}1.15 \\
(6,582)\end{array}$ & $\begin{array}{c}-78 \\
(3,290)\end{array}$ & $\begin{array}{c}1.95 \\
(3,290)\end{array}$ & $\begin{array}{c}1.26 \\
(6,582)\end{array}$ & $\begin{array}{c}1.67 \\
(6,582)\end{array}$ & $\frac{-88}{(3,290)}$ & $\begin{array}{c}1.26 \\
(6,582)\end{array}$ \\
\hline $\begin{array}{ll}\text { Negativity } & F \\
\text { Positivity } & F \\
\text { Control F } & F \\
\text { Univariate df }\end{array}$ & $\begin{array}{r}123.36^{\star \star \star} \\
41.28^{\star \star \star} \\
73.38^{\star \star \star} \\
(1,292)\end{array}$ & $\begin{array}{c}1.86 \\
-77 \\
-65 \\
(2,292)\end{array}$ & $\begin{array}{c}-38 \\
1.80 \\
-31 \\
(1,292)\end{array}$ & $\begin{array}{l}.84 \\
3.56 \\
2.37 \\
(1,292)\end{array}$ & $\begin{array}{c}1.91 \\
1.17 \\
-48 \\
(2,292)\end{array}$ & $\begin{array}{c}2.58 \\
.06 \\
2.21 \\
(2,292)\end{array}$ & $\begin{array}{c}.52 \\
.03 \\
2.13 \\
(1,292)\end{array}$ & $\begin{array}{c}.59 \\
-48 \\
2.42 \\
(2,292)\end{array}$ \\
\hline \multirow[t]{2}{*}{ Univariate Findings $^{a}$} & \multicolumn{8}{|c|}{ Interactions with Wave Effects } \\
\hline & $\begin{array}{l}\text { Main } \\
\text { Effect } \\
\text { for } \\
\text { Uave } \\
\end{array}$ & $\begin{array}{c}\text { Wave X } \\
\text { Pubertal } \\
\text { Growth } \\
\end{array}$ & $\begin{array}{c}\text { Wave } x \\
\text { Child } \\
\text { Sex } \\
\end{array}$ & $\begin{array}{c}\text { Uave } x \\
\text { Fanily } \\
\text { Type } \\
\end{array}$ & $\begin{array}{l}\text { Uave X } \\
\text { Pub_Gru } \\
\text { X Gender } \\
\end{array}$ & $\begin{array}{l}\text { Uave X } \\
\text { Pub_Gru } \\
\text { X Fanily } \\
\end{array}$ & $\begin{array}{l}\text { Wave } X \\
\text { Family } X \\
\text { Gender } \\
\end{array}$ & $\begin{array}{l}\text { Fanily } X \\
\text { Uave } X \\
\text { Gender } X \\
\text { Pub.Growth }\end{array}$ \\
\hline Negativity & $M 2>41$ & - & - & - & - & - & - & - \\
\hline Positivity & $\mathbf{N 1}>\mathbf{W R}$ & - & - & - & - & - & - & - \\
\hline Control & W1 > U2 & - & - & - & - & - & - & - \\
\hline
\end{tabular}


Table 22 (cont inued).

F-Values and Significant Levels for Multivariate Analyses of Fathers' Parenting (Family Type Analyses): Repeated Measures from Composite Ratings

Note: Multivariate test is Pillais.

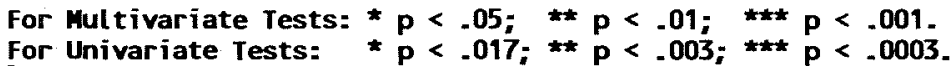

For Univariate Tests:
Univariate tests are follow-up tests based on multivariate results.

These results were based on the univariate sample.

bubertal Growth Group differences are post hoc tests.

Abbreviations

Family Type: Step = Stepfamily

Nondiv = Nondivorced fani lies

Pubertal Growth Groups: Early-Mid = Early-to-Mid Pubertal Growth Group

No Chng = No Change Pubertal Growth Group

Haves: $\mathrm{H} 1=$ Have 1

Mid-Late $=$ Mid-to-Late Pubertal Growth Group

U2 = Have 2 
Table 23.

Mothers' Control (Combined Ratings): Significant Differences in Regression slopes between Curvil inear Pubertal Growth and Maternal Control.

Beta Weights and Significance of Regression Line

$$
\begin{gathered}
\text { beta Change } \\
\text { Heights in R2 F-value }
\end{gathered}
$$

\begin{tabular}{|c|c|c|c|c|}
\hline $\begin{array}{l}\text { Overall Boys } \\
\text { overall Girls }\end{array}$ & $\begin{array}{l}167 \\
162\end{array}$ & $\begin{array}{r}.04 \\
-.11\end{array}$ & $\begin{array}{l}.00 \\
.01\end{array}$ & $\begin{array}{l}\text { n.s. } \\
\text { n.s. }\end{array}$ \\
\hline $\begin{array}{c}\text { Nondivorced/Owrness } \\
\text { Boys } \\
\text { Girls }\end{array}$ & $\begin{array}{r}169 \\
81 \\
88\end{array}$ & $\begin{array}{l}.14 \\
.06 \\
.18\end{array}$ & $\begin{array}{l}.02 \\
.00 \\
.03\end{array}$ & $\begin{array}{l}\text { n.s. } \\
\text { n.s. } \\
\text { n.s. }\end{array}$ \\
\hline $\begin{array}{c}\text { Stepfami ly/0umness } \\
\text { Boys } \\
\text { Girls }\end{array}$ & $\begin{array}{r}143 \\
77 \\
66\end{array}$ & $\begin{array}{l}-.23 \\
-.09 \\
-.38\end{array}$ & $\begin{array}{l}.06 \\
.01 \\
.14\end{array}$ & $\begin{array}{l}7.44^{*} \\
\text { n.s. } \\
10.45^{*}\end{array}$ \\
\hline $\begin{array}{c}\text { Stepfamily/Not own } \\
\text { Boys } \\
\text { Girls }\end{array}$ & $\begin{array}{r}17 \\
9 \\
8\end{array}$ & $\begin{array}{r}.00 \\
.71 \\
-.53\end{array}$ & $\begin{array}{l}.00 \\
.50 \\
.28\end{array}$ & $\begin{array}{l}\text { n.s. } \\
\text { n.s. } \\
\text { n.s. }\end{array}$ \\
\hline
\end{tabular}

Testing for significant Differences in Regression Lines

Omibus Test

\begin{tabular}{|c|c|c|}
\hline Overall Fanily Type/Omness Test & $\begin{aligned} 5.21^{\star} \\
10.56\end{aligned}$ & \\
\hline $\begin{array}{l}\text { Comparing Nondiv/Om vs. Step/Own } \\
\text { Comparing Nondiv/Own vs. Step/Not omn } \\
\text { Comparing Step/own vs. Step/Not Own }\end{array}$ & $\begin{array}{l}\text { 10.56* } \\
\text { n.s. } \\
\text { n.s. }\end{array}$ & Step/own \\
\hline Family Type/Ounness Within Gender & & \\
\hline $\begin{array}{l}\text { Boys: Overall } \\
\text { Boys: Nondiv/Own vs. Step/Own } \\
\text { Boys: Nondiv/Own vs. Step/Not own } \\
\text { Boys: Step/Om vs. Step/Not Own }\end{array}$ & $\begin{array}{l}\text { n.s. } \\
\text { n.s. } \\
\text { n.s. } \\
\text { n.s. }\end{array}$ & \\
\hline $\begin{array}{l}\text { Girls: Overall } \\
\text { Girls: Nondiv/Om vs. Step/own } \\
\text { Girls: Nondiv/Om vs. Step/Not own } \\
\text { Girls: Step/Om vs. Step/Not own }\end{array}$ & $\begin{array}{l}7.21 * \\
12.79 * * \\
\text { n.s. } \\
\text { n.s. }\end{array}$ & Step/own \\
\hline Overall Gender Test & n.s. & \\
\hline Gender within Family Type/Ounness Growp & & \\
\hline $\begin{array}{l}\text { Mondivorced/Omness } \\
\text { Stepfami ly/Omness } \\
\text { Stepfami ly/Not om }\end{array}$ & $\begin{array}{l}\text { n.s. } \\
\text { n.s. } \\
\text { n.s. }\end{array}$ & \\
\hline
\end{tabular}

Group with

Stronger

$\frac{\text { F-Value Relationship }}{4.18 *}$

$5.21 *$

n.s.

Note: Bonferroni alpha adjustments within each set of analyses.

Asterisks correspond to the common alpha levels: $*=\mathbf{p} \leq .05 ; * \star=\mathbf{p} \leq .01 ; \star \star \star=\mathbf{p} \leq .001$;

${ }^{1}$ The listed group was the most strongly related 
Table 24.

Fathers' Parenting by Differences Scores (Composite Ratings): Means and Standard Deviations from Multivariate Iables for Three Family Type/Oumness Groups.

$\frac{\text { NEGATIVITY }}{\text { MEAN (SD) N }} \quad \frac{\text { POSITIVITY }}{\text { MEAN (SD) N }} \quad \frac{\text { CONTROL }}{\text { MEAN (SD) N }}$

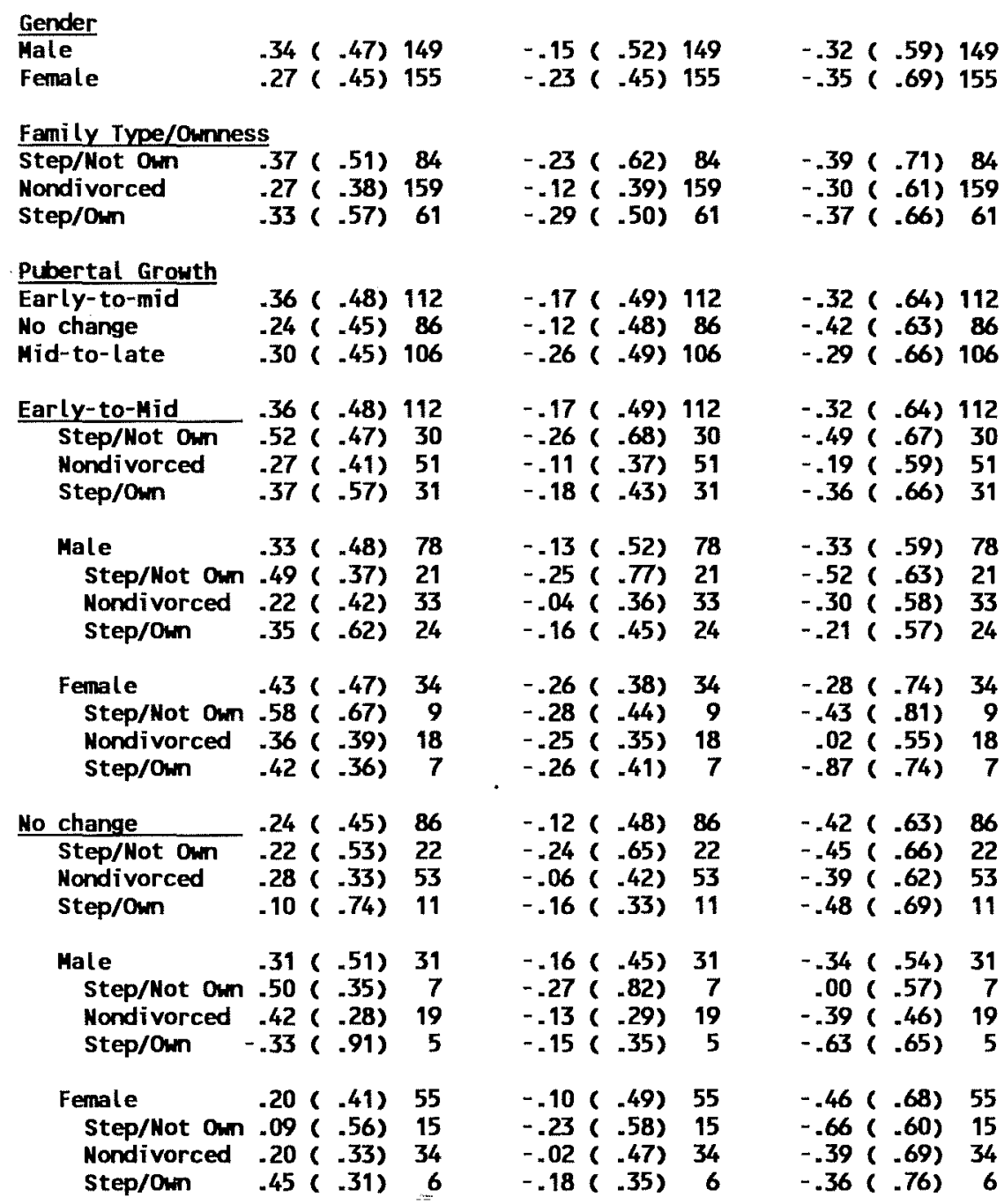


Table 24 (continued).

Fathers' Parenting by Differences Scores (Composite Ratings): Means and Standard Deviations from Multivariate Tables for Three Family Type/Owness Groups.

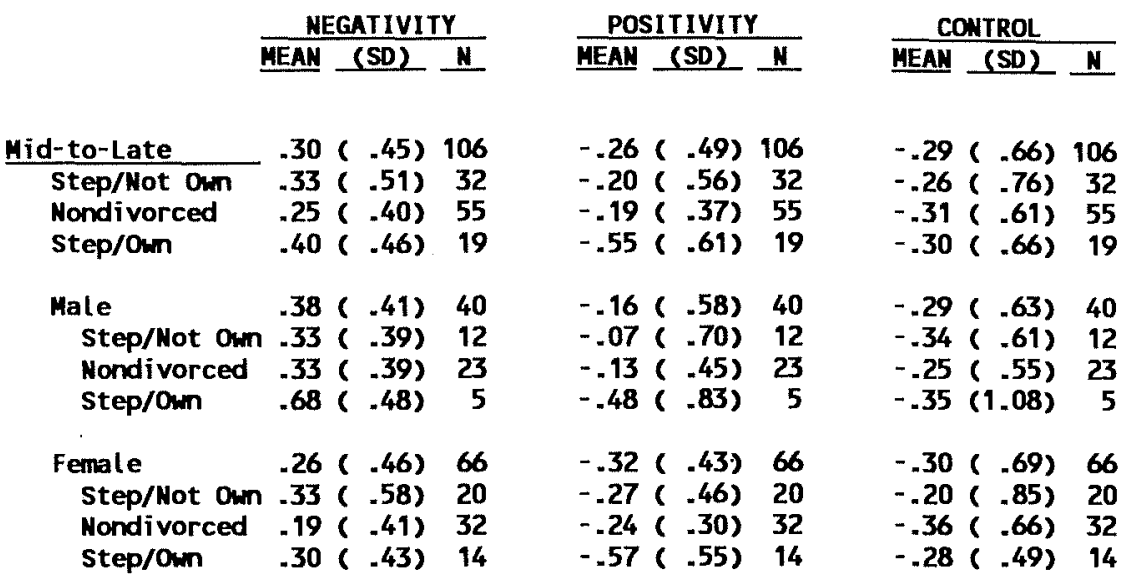

Note: Step/Not $\mathrm{am}_{\mathrm{m}}=$ Stepfather-adolescent relationships step/Om = Biological father-adolescent relationships in stepfamilies 
Parent-Adolescent Relations and Puberty

Table 25.

F-Values and Significant Levels for Multivariate Analyses of Father's Parenting (Fami ly Type/Oumess Analyses): Difference Scores from Composite Ratings.

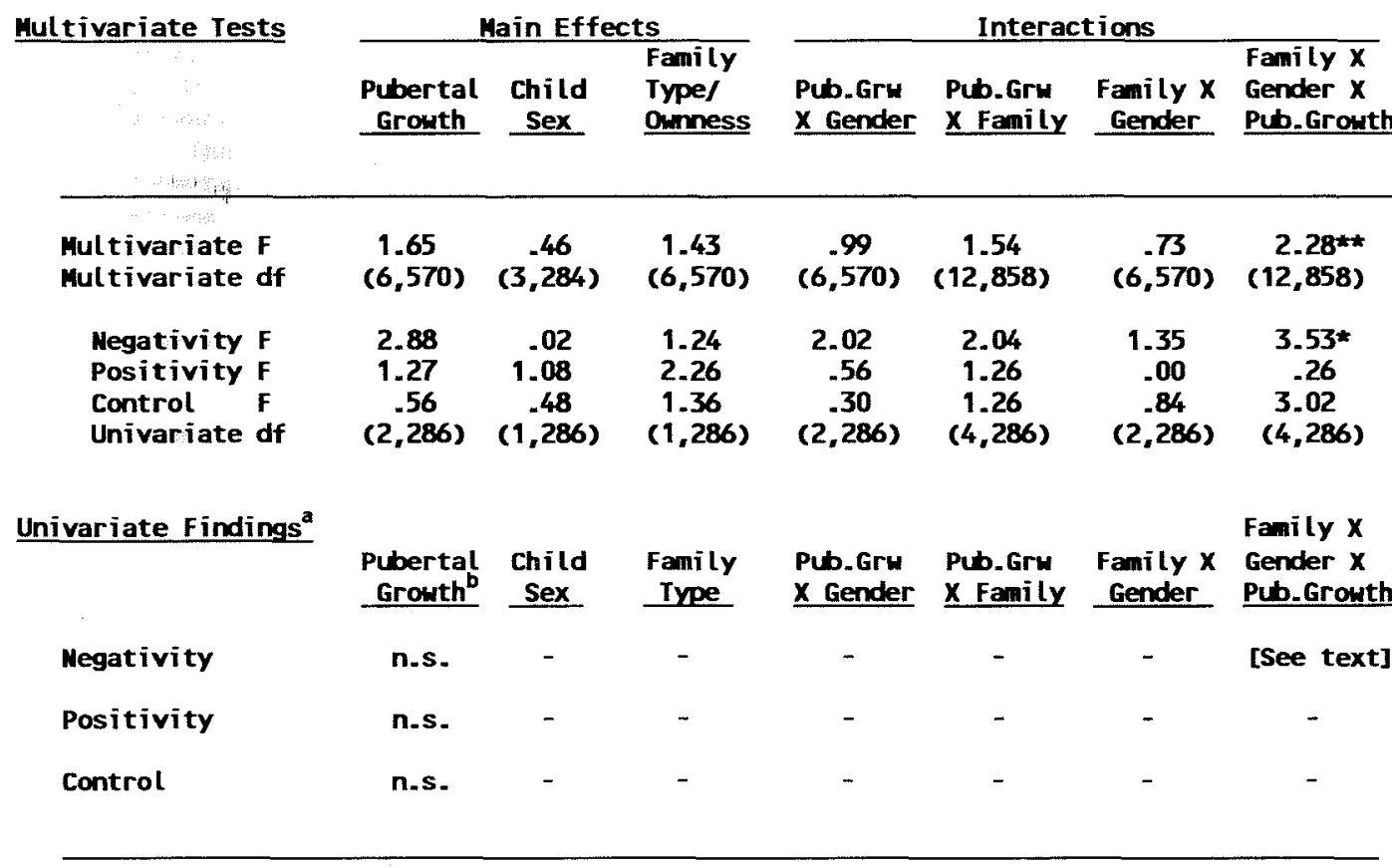


Table 25 (continued).

F-Values and Significant Levels for Multivariate Analyses of Father's Parenting (Family Type/Oumess Analyses): Difference Scores from Composite Ratings.

Note: Multivariate test is Pillais.

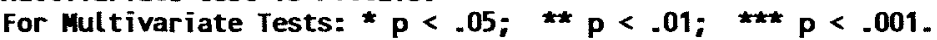

For Univariate Tests: $\quad * p<.017 ; * p_{0}<.003 ; \star \star \star p<.0003$.

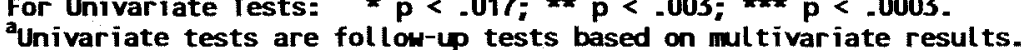

These results were based on the univariate sample.

bubertal Growth Group differences are post hoc tests.

Abbreviations

Family Type: Step = Biological Relationship within Stepfamily

Nondiv = Mondivorced families

Not Own = Stepfather-child Relationship

Pubertal Growth Groups: Early-Mid = Early-to-Mid Pubertal Growth Group

No Chng = No Change Pubertal Growth Group

Uaves: $\mathrm{H1}=$ Wave 1

Mid-Late = Mid-to-Late Pubertal Growth Group

UR = Nave 2 
Parent-Adolescent Relations and Puberty

Table 26.

Fathers' Parenting by Composite Scores Have 1 and Have 2 (Repeated Measures) Multivariate Means and Standard Deviations for Three Family Type/Omness Groups.

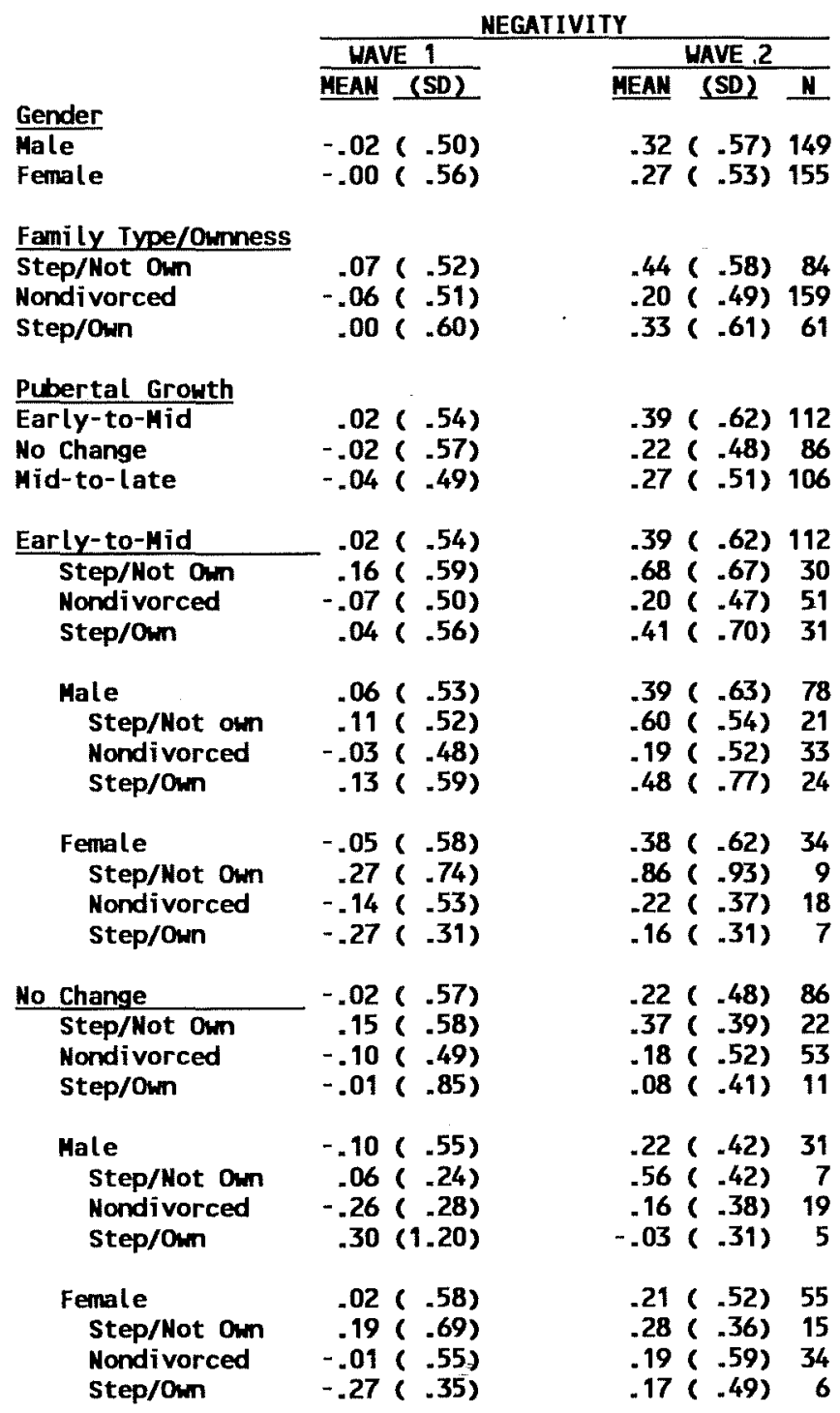


Table 26 (Continued).

Fathers' Parenting by Composite Scores Wave 1 and Wave 2 (Repeated Measures) Mult ivariate Means and Standard Deviations for Three Family Type/Owness Groups.

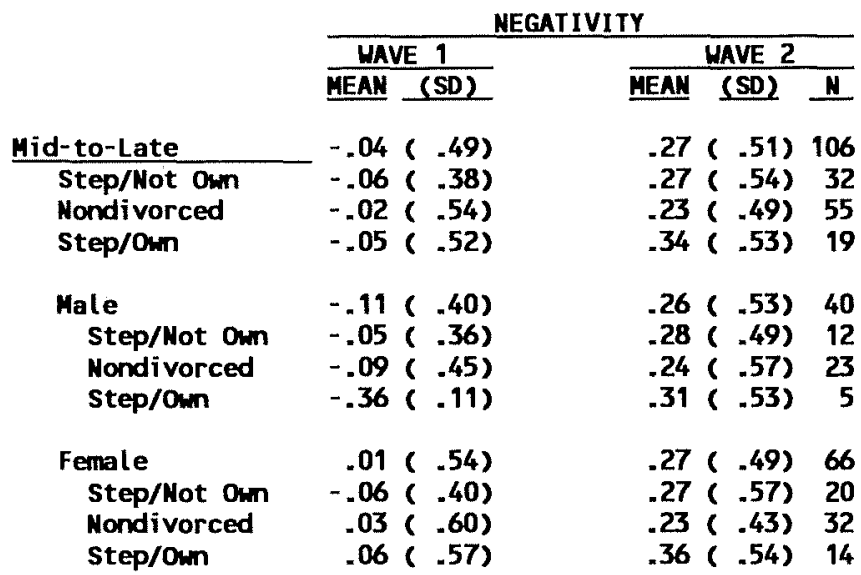

Note: step/not own $=$ stepfather-adolescent relationship step/own = stepfanily with biological father-adolescent relationship nondiv/own = non-stepfamily with biological father-adolescent relationship 
Table 26 (Continued)

Fathers' Parenting by Composite Scores Mave 1 and Have 2 (Repeated Measures) Mul tivariate Means and Standard Deviations for Three Family Type/Ounness Groups.

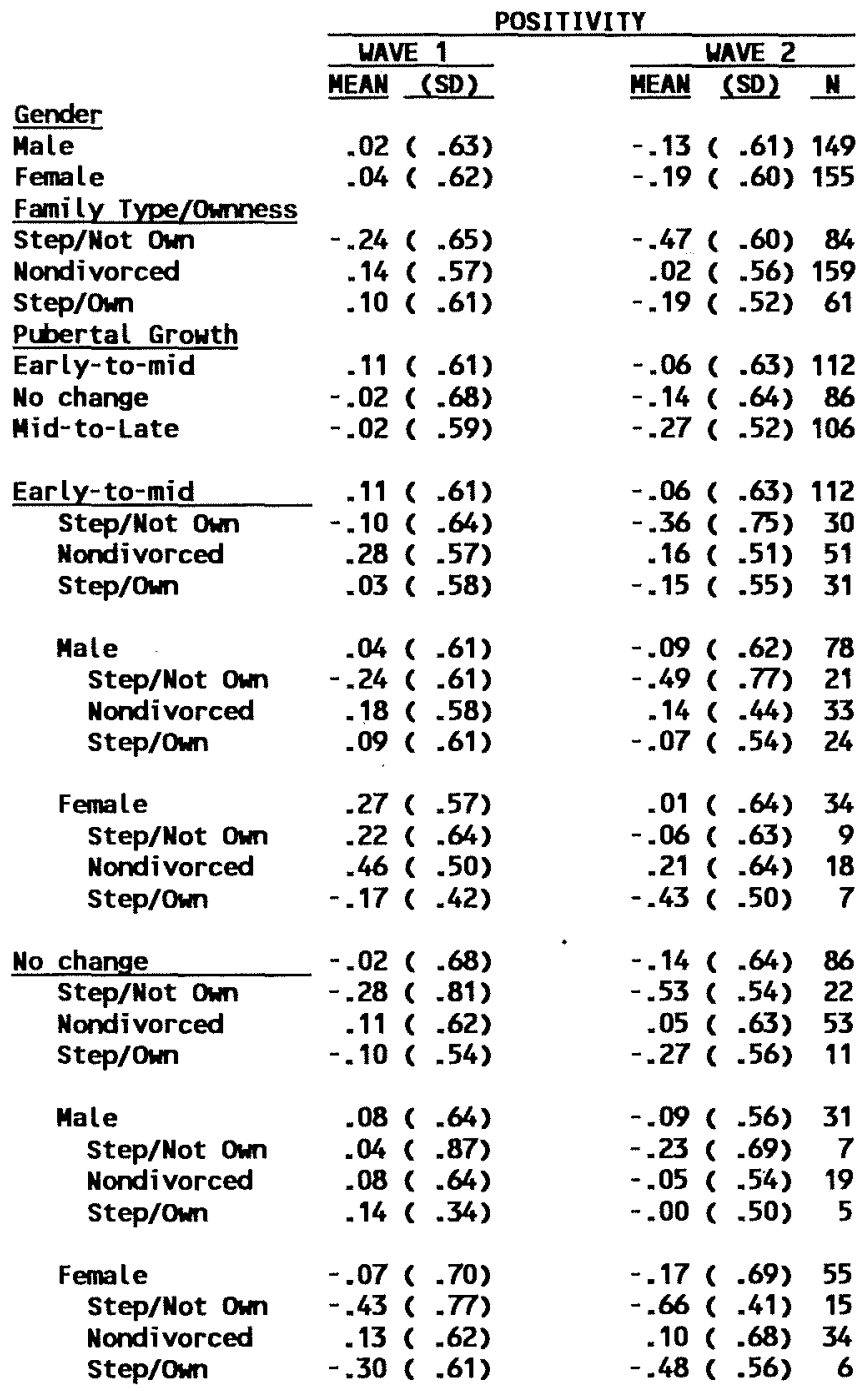


Table 26 (continued)

Fathers' Parenting by Composite Scores Mave 1 and Mave 2 (Repeated Measures) Multivariate Means and standard Deviations for Three Family Type/Owmess Groups.

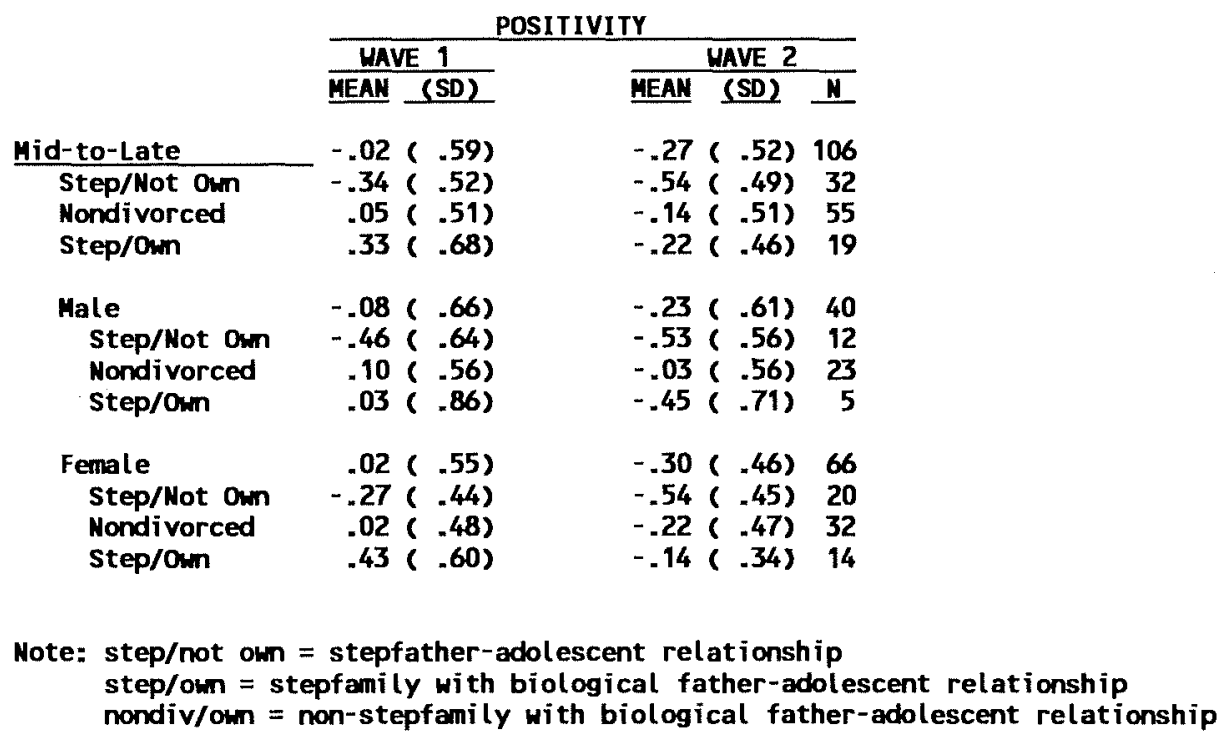


Table 26 (cont inued)

Fathers' Parenting by Composite Scores Wave 1 and Wave 2 (Repeated Measures) Mult ivariate Means and Standard Deviations for Three Family Type/Ourness Groups.

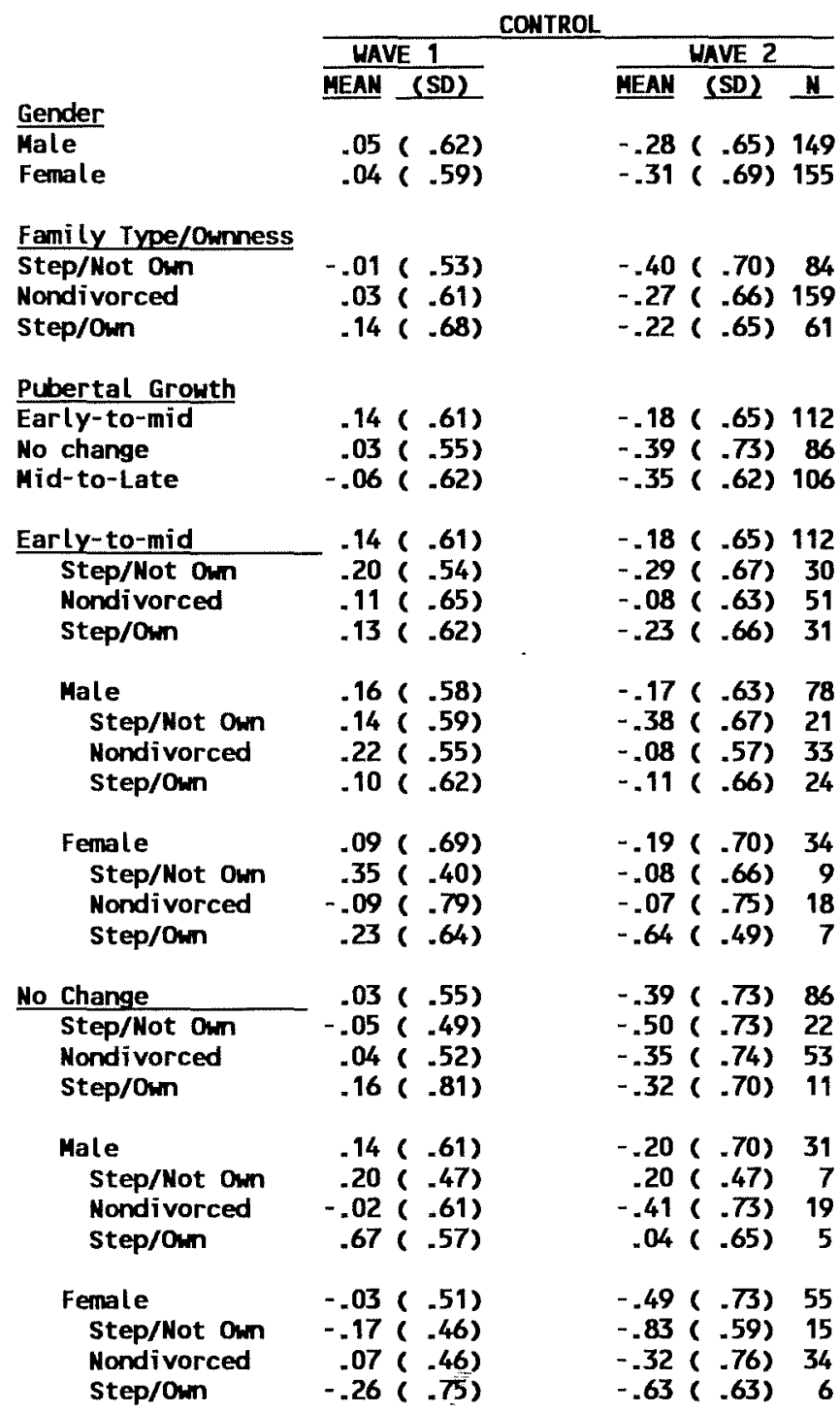


Table 26 (continued)

Fathers' Parenting by Composite Scores Wave 1 and Wave 2 (Repeated Measures) Mul tivari ate Means and Standard Deviations for Three Fanily Type/Owness Groups.

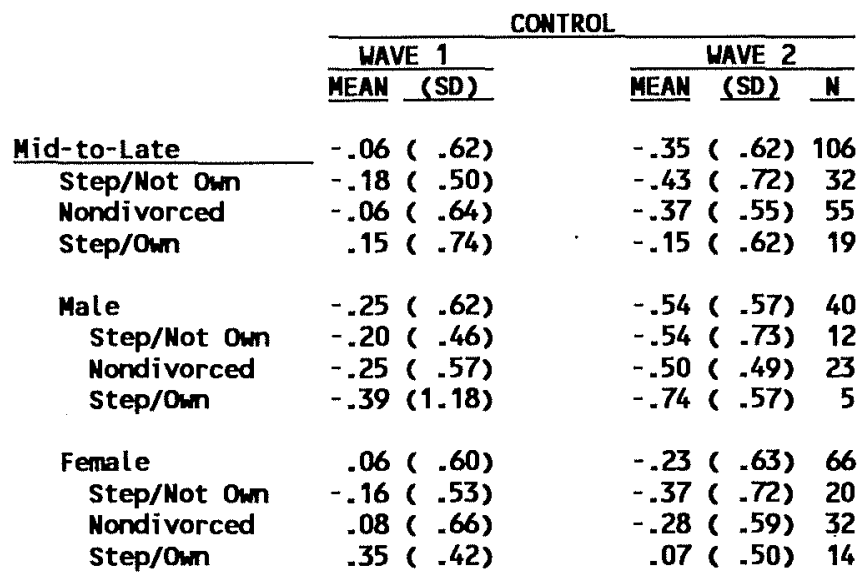

Note: step/not own = stepfather-adolescent relationship step/own = stepfamily with biological father-adolescent relationship nondiv/own = non-stepfamily with biological father-adolescent relationship 
Parent-Adolescent Relations and Puberty

Table 27.

F-Values and Significant Levels for Multivariate Analyses of Father's Parenting (Family Iype/Ommess Analyses): Repeated Measures from Composite Ratings.

\begin{tabular}{|c|c|c|c|c|c|c|c|}
\hline \multirow{2}{*}{ Multivariate Tests } & \multicolumn{3}{|c|}{ Main Effects } & \multicolumn{4}{|c|}{ Interactions } \\
\hline & $\begin{array}{c}\text { Pubertal } \\
\text { Growth } \\
\end{array}$ & $\begin{array}{l}\text { Child } \\
\text { Sex } \\
\end{array}$ & $\begin{array}{l}\text { Family } \\
\text { Iype }\end{array}$ & $\begin{array}{l}\text { Pub.Gru } \\
X \text { Gender }\end{array}$ & $\begin{array}{l}\text { Pub.Gru } \\
\text { X Family }\end{array}$ & $\begin{array}{l}\text { Family } x \\
\text { Gender }\end{array}$ & $\begin{array}{l}\text { Family X } \\
\text { Gender X } \\
\text { Pub.Growth }\end{array}$ \\
\hline $\begin{array}{l}\text { Multivariate } F \\
\text { Multivariate df }\end{array}$ & $\begin{array}{c}1.67 \\
(6,570)\end{array}$ & $\begin{array}{c}-09 \\
(3,284)\end{array}$ & $\begin{array}{l}6.42^{\star \star *} \\
(6,570)\end{array}$ & $\begin{array}{r}3.72^{\star \star} \\
(6,570)\end{array}$ & $\begin{array}{c}-94 \\
(12,858)\end{array}$ & $\begin{array}{c}-64 \\
(6,570)\end{array}$ & $\begin{array}{c}2.21 * \\
(12,858)\end{array}$ \\
\hline $\begin{array}{ll}\text { Megativity } F \\
\text { Positivity } \\
\text { Control F } \\
\text { Univariate df }\end{array}$ & $\begin{array}{l}1.31 \\
2.04 \\
3.21 \\
(2,286)\end{array}$ & $\begin{array}{c}-00 \\
-09 \\
-28 \\
(1,286)\end{array}$ & $\begin{array}{c}5.11^{\star \star} \\
14.35^{\star \star *} \\
.09 \\
(2,286)\end{array}$ & $\begin{array}{c}.55 \\
2.59 \\
10.44^{\star \star \star} \\
(2,286)\end{array}$ & $\begin{array}{c}1.52 \\
1.06 \\
-47 \\
(4,286)\end{array}$ & $\begin{array}{c}-46 \\
-55 \\
-86 \\
(2,286)\end{array}$ & $\begin{array}{c}1.20 \\
3.17^{\star} \\
4.36 \star \star \\
(4,286)\end{array}$ \\
\hline Univariate Findings $^{\mathbf{a}}$ & $\begin{array}{l}\text { Pubertal } \\
\text { Growth }^{\mathrm{b}} \\
\end{array}$ & $\begin{array}{l}\text { Child } \\
\text { Sex } \\
\end{array}$ & $\begin{array}{l}\text { Family } \\
\text { Type }\end{array}$ & $\begin{array}{l}\text { Pub_Grw } \\
\text { X Gender }\end{array}$ & $\begin{array}{l}\text { Pub_Gru } \\
\text { X Fanily }\end{array}$ & $\begin{array}{l}\text { Fami ly } x \\
\text { Gender }\end{array}$ & $\begin{array}{l}\text { Fanily } X \\
\text { Gender } X \\
\text { Pub_Growth }\end{array}$ \\
\hline Negativity & n.s. & - & $\begin{array}{l}\text { Mot Om } \\
>\text { Mondiv }\end{array}$ & - & - & - & - \\
\hline Positivity & n.s. & - & $\begin{array}{l}\text { Nondiv > } \\
\text { Mot Own }\end{array}$ & - & - & - & [See text] \\
\hline Control & n.s. & - & - & $\begin{array}{l}\text { Mid-Late: } \\
\text { Girls > } \\
\text { Boys }\end{array}$ & : & - & [See text] \\
\hline
\end{tabular}


Table 27 (cont inued)

F-Values and Significant Levels for Multivariate Analyses of Father's Parenting (Fami ly Type/Oumess Analyses): Repeated Measures from Composite Ratings.

\begin{tabular}{|c|c|c|c|c|c|c|c|c|}
\hline \multirow[t]{2}{*}{ Multivariate Tests } & \multirow[b]{2}{*}{$\begin{array}{l}\text { Main } \\
\text { Effect } \\
\text { for } \\
\text { Uave } \\
\end{array}$} & \multicolumn{6}{|c|}{ Interactions with Wave Effects } & \multirow[b]{2}{*}{$\begin{array}{l}\text { Fami ly } X \\
\text { Uave } X \\
\text { Gender } X \\
\text { Pub_Growth } \\
\end{array}$} \\
\hline & & $\begin{array}{l}\text { Wave X } \\
\text { Pubertal } \\
\text { Growth } \\
\end{array}$ & $\begin{array}{r}\text { Wave } X \\
\text { Child } \\
\text { Sex } \\
\end{array}$ & $\begin{array}{l}\text { Wave } x \\
\text { Family } \\
\text { Type } \\
\end{array}$ & $\begin{array}{l}\text { Uave } X \\
\text { Pub_Gru } \\
\text { X Gender }\end{array}$ & $\begin{array}{l}\text { Wave } X \\
\text { Pub_Gru } \\
\text { X Family }\end{array}$ & $\begin{array}{l}\text { Wave } x \\
\text { Fani ly } x \\
\text { Gender }\end{array}$ & \\
\hline $\begin{array}{l}\text { Multivariate } F \\
\text { Multivariate } d f\end{array}$ & $\begin{array}{l}66.21 \star \star \star \\
(3,284)\end{array}$ & $\begin{array}{c}1.65 \\
(6,570)\end{array}$ & $\frac{-46}{(3,284)}$ & $\begin{array}{c}1.43 \\
(6,570)\end{array}$ & $\begin{array}{c}.99 \\
(6,570)\end{array}$ & $\begin{array}{c}1.54 \\
(12,858)\end{array}$ & $\begin{array}{c}-73 \\
(6,570)\end{array}$ & $\begin{array}{r}2.28 * \star \\
(12,858)\end{array}$ \\
\hline $\begin{array}{ll}\text { Negativity } & F \\
\text { Positivity } & F \\
\text { Control } & F \\
\text { Univariate } & \text { df }\end{array}$ & $\begin{array}{r}110.98^{\star \star \star} \\
42.95^{\star \star \star} \\
66.63^{\star \star \star} \\
(1.286)\end{array}$ & $\begin{array}{c}2.88 \\
1.27 \\
-56 \\
(2,286)\end{array}$ & $\begin{array}{c}.02 \\
1.08 \\
-48 \\
(1,286)\end{array}$ & $\begin{array}{c}1.24 \\
2.26 \\
1.36 \\
(2.286)\end{array}$ & $\begin{array}{c}2.02 \\
-56 \\
-30 \\
(2,286)\end{array}$ & $\begin{array}{c}2.04 \\
1.26 \\
1.26 \\
(4,286)\end{array}$ & $\begin{array}{c}1.35 \\
-00 \\
-84 \\
(2,286)\end{array}$ & $\begin{array}{c}3.53^{\star *} \\
-26 \\
3.02 \\
(2.286)\end{array}$ \\
\hline \multirow[t]{2}{*}{ Univariate Findings $^{a}$} & \multicolumn{8}{|c|}{ Interactions with Wave Effects } \\
\hline & $\begin{array}{l}\text { Main } \\
\text { Effect } \\
\text { for } \\
\text { Mave } \\
\end{array}$ & $\begin{array}{c}\text { Wave } x \\
\text { Pubertal } \\
\text { Growth } \\
\end{array}$ & $\begin{array}{r}\text { Wave } x \\
\text { Child } \\
\text { Sex } \\
\end{array}$ & $\begin{array}{l}\text { Wave } x \\
\text { Family } \\
\text { Type } \\
\end{array}$ & $\begin{array}{l}\text { Wave X } \\
\text { Pub.Grw } \\
\text { X Gender } \\
\end{array}$ & $\begin{array}{l}\text { Wave X } \\
\text { Pub.Gru } \\
\text { X Family }\end{array}$ & $\begin{array}{l}\text { Wave } X \\
\text { Family } x \\
\text { Gender } \\
\end{array}$ & $\begin{array}{l}\text { Fami ty } x \\
\text { Wave } X \\
\text { Gender } X \\
\text { Pub_Grouth } \\
\end{array}$ \\
\hline Negativity & $W 2>W 1$ & - & - & - & - & - & - & [See text] \\
\hline Positivity & $\mathrm{H1}>\mathrm{MR}$ & - & - & - & - & - & - & - \\
\hline Control & $\mathrm{W1}>\mathrm{W} 2$ & - & - & - & - & - & - & - \\
\hline
\end{tabular}


Table 27 (continued)

F-Values and Significant Levels for Multivariate Analyses of Father's Parenting (Family Type/Omness Analyses): Repeated Measures from Composite Ratings.

Note: Multivariate test is Pillais.

For Multivariate Tests: $* p<.05 ; \star \star p<.01 ; \star \star \star p<.001$.

For Univariate Tests: $\neq p<.017 ; * \neq<.003 ; * * \neq<.0003$.

Univariate tests are follow-up tests based on multivariate results.

These results were based on the univariate sample.

bubertal Growth Group differences are post hoc tests.

Abbreviations

Family Type: Step = Biological Relationship within Stepfamily

Mondiv = Mondivorced families

Not own = Stepfather-child Relationship

Pubertal Growth Groups: Early-Mid = Early-to-Mid Pubertal Growth Group

No Chng = No Change Pubertal Growth Group

Waves: $\mathbf{H 1}=$ Have

Mid-Late $=$ Mid-to-Late Pubertal Growth Group

$\mathbf{L}$ = Uave 2 
Table 28.

Mothers' Parenting by Differences Scores (Mothers' Ratings): Univariate Means and Standard Deviations.

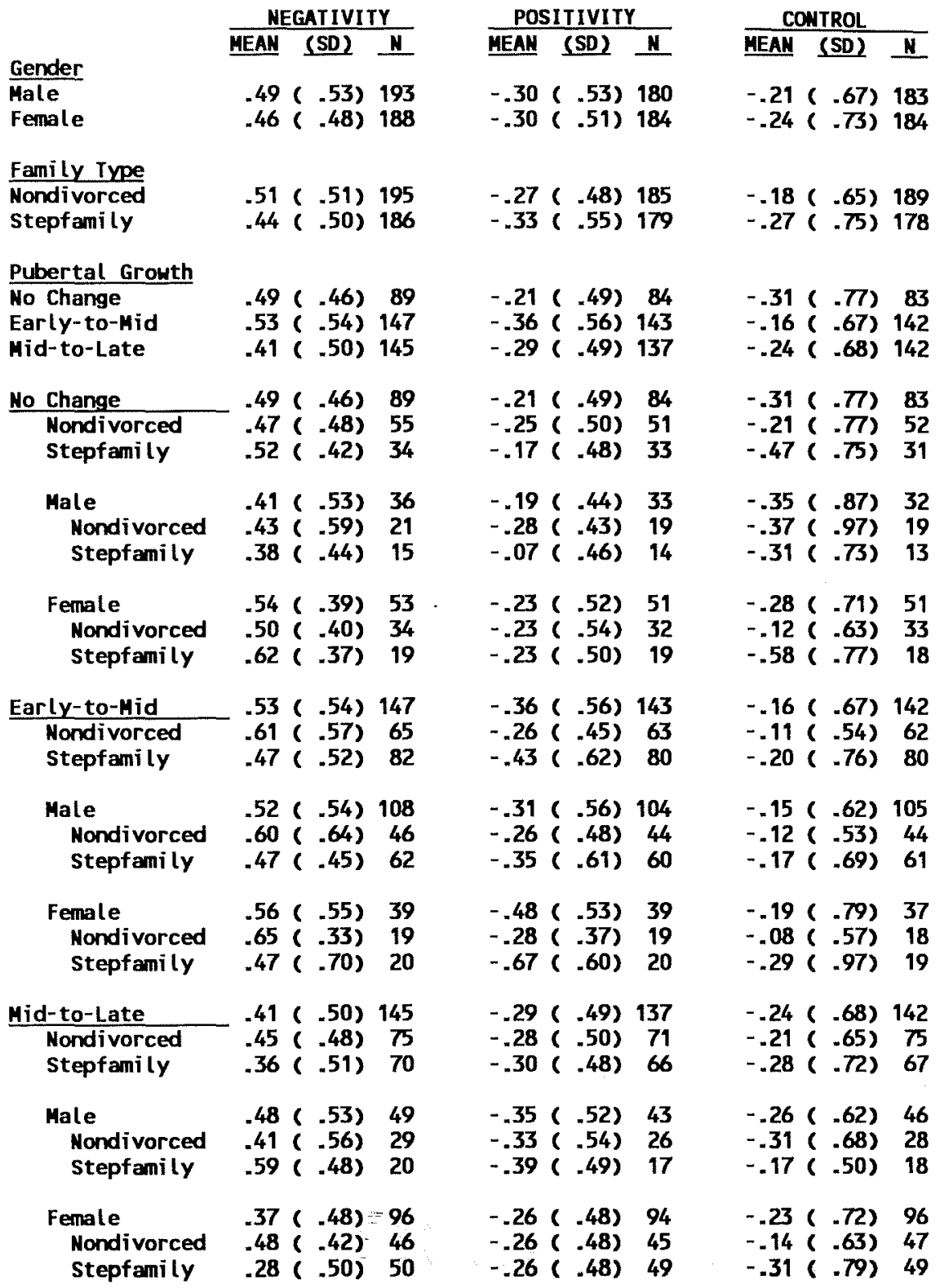


Parent-Adolescent Relations and Puberty

Table 29.

F-Values and Significant Levels for Multivariate Analyses of Mother's Parenting: Difference Scores from Mothers' Ratings.

\begin{tabular}{|c|c|c|c|c|c|c|c|}
\hline \multirow[t]{2}{*}{ Multivariate Tests } & \multicolumn{3}{|c|}{ Main Effects } & \multicolumn{3}{|c|}{ Interactions } & \multirow[b]{2}{*}{$\begin{array}{l}\text { Family } x \\
\text { Gender } x \\
\text { Pub.Growth } \\
\end{array}$} \\
\hline & $\begin{array}{l}\text { Pubertal } \\
\text { Growth } \\
\end{array}$ & $\begin{array}{l}\text { Child } \\
\text { Sex } \\
\end{array}$ & $\begin{array}{l}\text { Family } \\
\text { Type }\end{array}$ & $\begin{array}{l}\text { Pub.Grw } \\
\text { X Gender }\end{array}$ & $\begin{array}{l}\text { Pub_Gru } \\
\text { X Family }\end{array}$ & $\begin{array}{l}\text { Fani ly } X \\
\text { Gender }\end{array}$ & \\
\hline $\begin{array}{l}\text { Multivariate } F \\
\text { Multivariate df }\end{array}$ & $\begin{array}{c}1.82 \\
(6,686)\end{array}$ & $\begin{array}{c}-15 \\
(3,342)\end{array}$ & $\begin{array}{c}1.06 \\
(3,342)\end{array}$ & $\begin{array}{c}1.12 \\
(6,686)\end{array}$ & $\begin{array}{c}1.54 \\
(6,686)\end{array}$ & $\begin{array}{c}1.95 \\
(3,342)\end{array}$ & $\begin{array}{c}.81 \\
(6,686)\end{array}$ \\
\hline $\begin{array}{l}\text { Negativity } F \\
\text { Positivity } F \\
\text { Control F F } \\
\text { Univariate df }\end{array}$ & $\begin{array}{c}1.37 \\
2.40 \\
1.35 \\
(2,344)\end{array}$ & $\begin{array}{c}-11 \\
.31 \\
.06 \\
(1,344)\end{array}$ & $\begin{array}{c}-49 \\
1.24 \\
1.69 \\
(1,344)\end{array}$ & $\begin{array}{c}1.57 \\
1.79 \\
.03 \\
(2,344)\end{array}$ & $\begin{array}{c}1.50 \\
2.46 \\
-61 \\
(2,344)\end{array}$ & $\begin{array}{c}.85 \\
1.03 \\
4.29 \\
(1.344)\end{array}$ & $\begin{array}{c}1.55 \\
.47 \\
.42 \\
(2,344)\end{array}$ \\
\hline Univariate Findings & $\begin{array}{l}\text { Pubertal } \\
\text { Growth }^{\mathrm{b}} \\
\end{array}$ & $\begin{array}{l}\text { Child } \\
\text { Sex } \\
\end{array}$ & $\begin{array}{l}\text { Family } \\
\text { Type }\end{array}$ & $\begin{array}{l}\text { Pub_Grw } \\
\text { X Gender }\end{array}$ & $\begin{array}{l}\text { Pub_Gru } \\
\text { X Family }\end{array}$ & $\begin{array}{l}\text { Fami ly } x \\
\text { Gender }\end{array}$ & $\begin{array}{l}\text { Fani Ly X } \\
\text { Gender } X \\
\text { Pub_Growth }\end{array}$ \\
\hline Negativity & n.s. & - & - & - & - & - & - \\
\hline Positivity & n.s. & - & - & - & - & - & - \\
\hline Control & n.s. & - & - & - & - & - & - \\
\hline
\end{tabular}


Table 29 (continued).

F-Values and Significant Levels for Multivariate Analyses of Mother's Parenting: Difference Scores from Mothers' Ratings-

Note: Multivariate test is Pillais.

For Multivariate Tests: $\star p<.05 ; * \neq p<.01 ; * \star * p<.001$.

For Univariate Tests: * $p<.017 ; \star \star p<.003 ; * \star * p<.0003$.

anivariate tests are follow-up tests based on multivariate results.

These results were based on the univariate sample.

bubertal Growth Group differences are post hoc tests.

\section{Abbreviations}

Fami ly Type: Step = Stepfami ly

Nondiv = Nondivorced families

Pubertal Growth Groups: Early-Mid = Early-to-Mid Pubertal Growth Group

No Chng = No Change Pubertal Growth Group

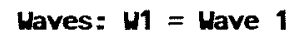

Mid-Late $=$ Mid-to-Late Pubertal Growth Group

WR = Wave 2
WR 
Table 30 .

Mothers' Parenting by Mothers' Report Wave 1 and Wave 2 (Repeated Measures)

Univariate Means and Standard Deviations.

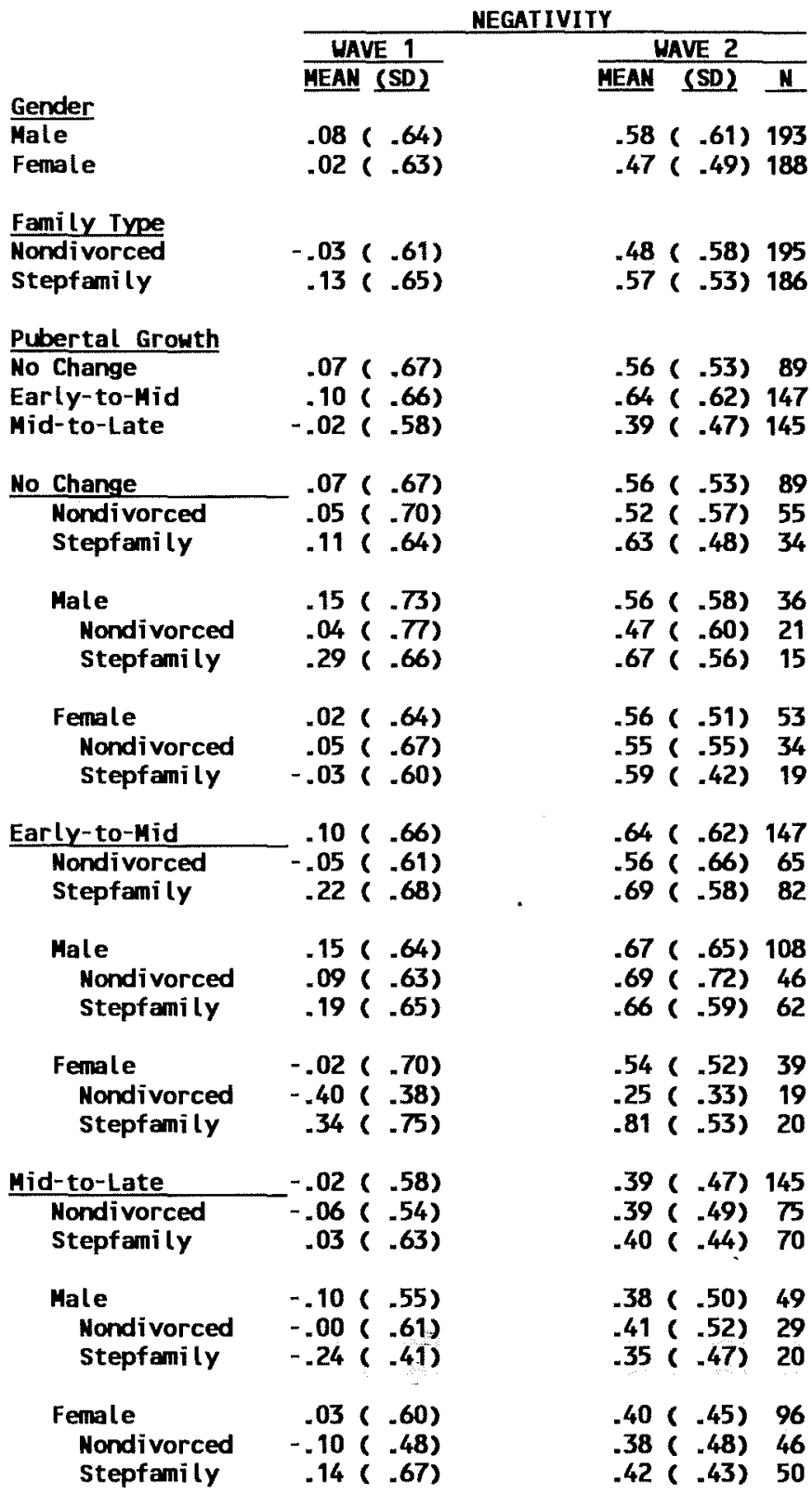


Table 30 (Cont inued).

Mothers' Parenting by Mothers' Report Wave 1 and Lave 2 (Repeated Measures) Univariate Means and Standard Deviations.

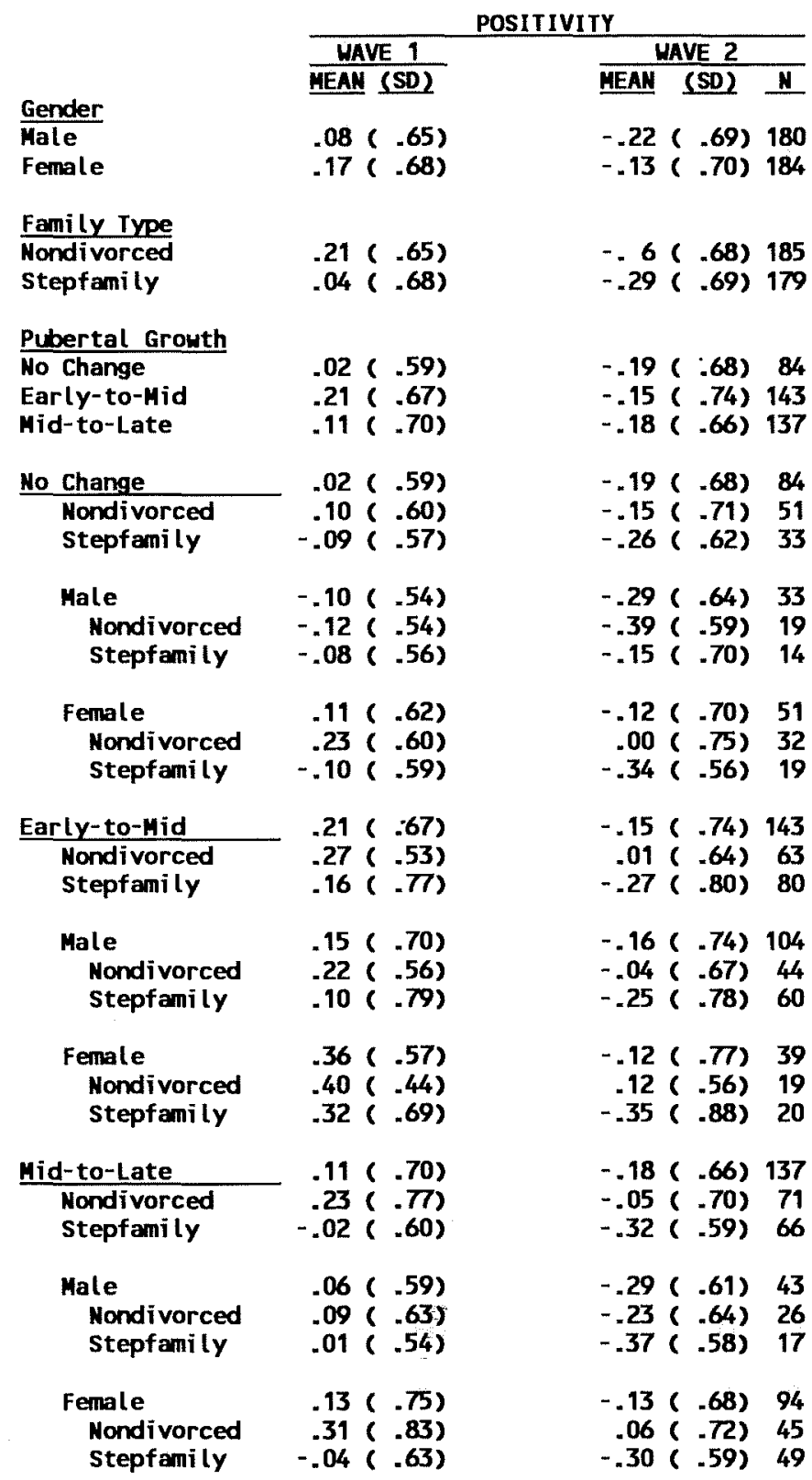


Table 30 (continued).

Mothers' Parenting by Mothers' Report Wave 1 and Wave 2 (Repeated Measures)

Univariate Means and Standard Deviations.

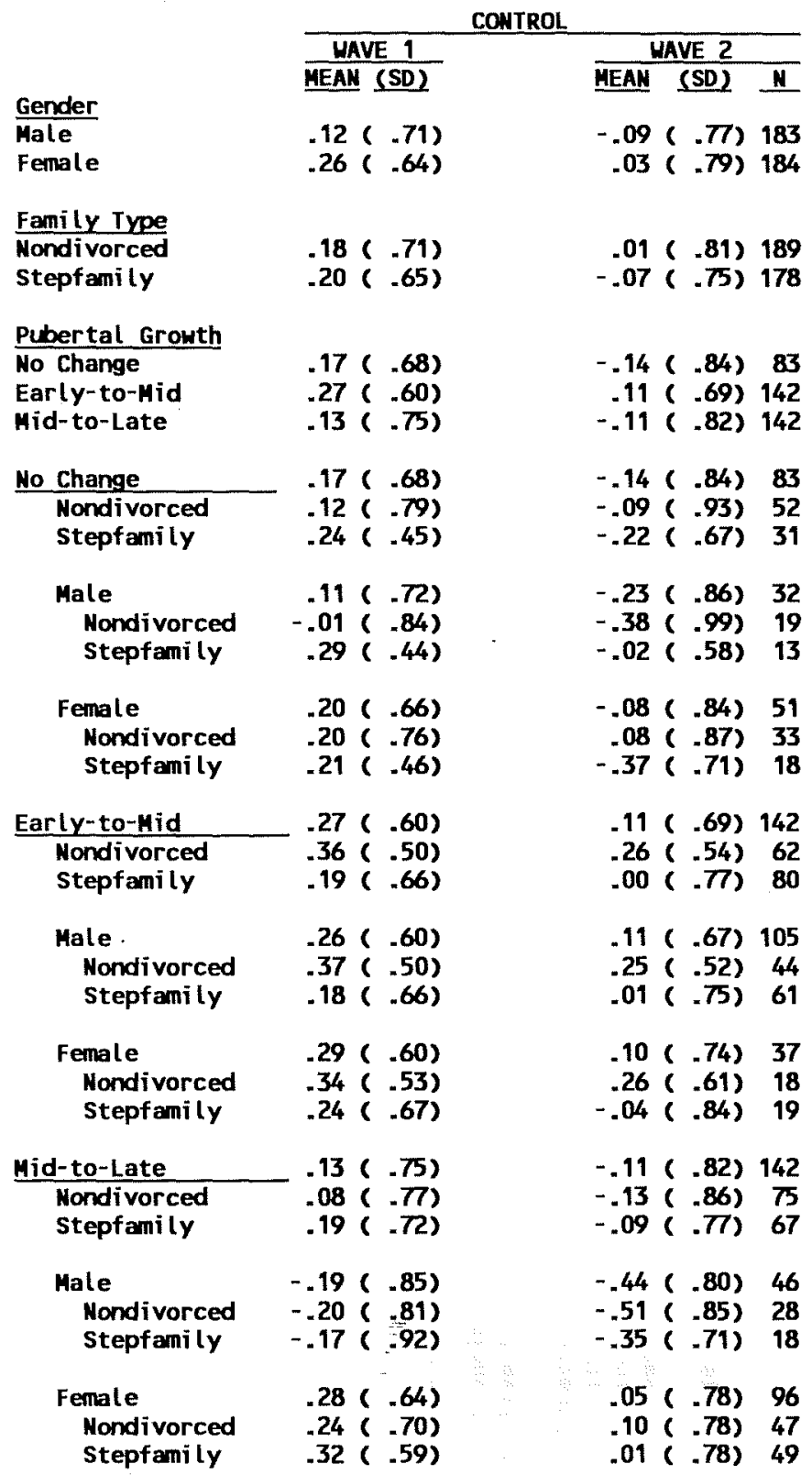


Parent-Adolescent Relations and Puberty

152

Table 31.

F-Values and Significant Levels for Multivariate Analyses of Mother's Parenting: Repeated Measures from Mothers' Ratings.

\begin{tabular}{|c|c|c|c|c|c|c|c|}
\hline \multirow{2}{*}{ Multivariate lests } & \multicolumn{3}{|c|}{ Main Effects } & \multicolumn{4}{|c|}{ Interactions } \\
\hline & $\begin{array}{l}\text { Pubertal } \\
\text { Growth }\end{array}$ & $\begin{array}{l}\text { Child } \\
\text { Sex } \\
\end{array}$ & $\begin{array}{l}\text { Family } \\
\text { Type }\end{array}$ & $\begin{array}{l}\text { Pub.Gru } \\
\text { X Gender }\end{array}$ & $\begin{array}{l}\text { Pub.Gru } \\
\text { X Fanily } \\
\end{array}$ & $\begin{array}{l}\text { Fani ly } x \\
\text { Gender } \\
\end{array}$ & $\begin{array}{l}\text { Family } X \\
\text { Gender X } \\
\text { Pub.Growth }\end{array}$ \\
\hline 1.34 & & & & & & & \\
\hline $\begin{array}{l}\text { Multivariate } F \\
\text { Multivariate df }\end{array}$ & $\begin{array}{l}3.66^{* * *} \\
(6,686)\end{array}$ & $\begin{array}{c}2.65^{\star} \\
(3,342)\end{array}$ & $\begin{array}{l}3.57 \\
(3,342)\end{array}$ & $\begin{array}{l}2.17 \\
(6,686)\end{array}$ & $\begin{array}{c}1.85 \\
(6,686)\end{array}$ & $\begin{array}{l}2.07 \\
(3,342)\end{array}$ & $\begin{array}{c}1.89 \\
(6,686)\end{array}$ \\
\hline $\begin{array}{ll}\text { Megativity } & F \\
\text { Positivity } & F \\
\text { Control F } & F \\
\text { Univariate df }\end{array}$ & $\begin{array}{l}4.05 \\
2.35 \\
5.88^{* *} \\
(2,344)\end{array}$ & $\begin{array}{c}-44 \\
4.17 \\
5.63 * \\
(1,344)\end{array}$ & $\begin{array}{c}5.41 \\
6.07 \star \\
.08 \\
(1.344)\end{array}$ & $\begin{array}{c}1.74 \\
.02 \\
4.60^{\star} \\
(2,344)\end{array}$ & $\begin{array}{c}3.38 \\
.28 \\
1.77 \\
(2.344)\end{array}$ & $\begin{array}{c}2.58 \\
2.85 \\
2.24 \\
(1,344)\end{array}$ & $\begin{array}{c}4.48^{\star} \\
-32 \\
1.07 \\
(2,344)\end{array}$ \\
\hline Univariate Findings ${ }^{a}$ & $\begin{array}{l}\text { Pubertal } \\
\text { Growth } \\
\end{array}$ & $\begin{array}{l}\text { Child } \\
\text { Sex } \\
\end{array}$ & $\begin{array}{l}\text { Fanily } \\
\text { Type }\end{array}$ & $\begin{array}{l}\text { Pub_Grw } \\
\text { X Gender }\end{array}$ & $\begin{array}{l}\text { Pub.Gru } \\
\text { X Family }\end{array}$ & $\begin{array}{l}\text { Fani ly X } \\
\text { Gender }\end{array}$ & $\begin{array}{l}\text { Fami ly } X \\
\text { Gender X } \\
\text { Pub.Growth }\end{array}$ \\
\hline Megativity & $\begin{array}{l}\text { [Early-Mid } \\
\text { > Mid-Late] }\end{array}$ & d - & - & - & - & - & [see text] \\
\hline Positivity & n.s. & - & $\begin{array}{l}\text { [Mondiv > } \\
\text { Step] }\end{array}$ & - & - & - & - \\
\hline Control & $\begin{aligned} & \text { Early-Mid } \\
&>\text { Mid-Late }\end{aligned}$ & $\begin{array}{c}\text { Gīrls > } \\
\text { Boys }\end{array}$ & - & $\begin{array}{l}\text { [Mid-Late: } \\
\text { iirls > Boy }\end{array}$ & - & - & - \\
\hline
\end{tabular}


Table 31 (Continued)

F-Values and Significant Levels for Multivariate Analyses of Mother's Parenting: Repeated Measures from Mothers' Ratings.

\begin{tabular}{|c|c|c|c|c|c|c|c|c|}
\hline \multirow[b]{2}{*}{ Multivariate Tests } & \multirow[b]{2}{*}{$\begin{array}{l}\text { Main } \\
\text { Effect } \\
\text { for } \\
\text { Uave } \\
\end{array}$} & \multicolumn{6}{|c|}{ Interactions with Have Effects } & \multirow[b]{2}{*}{$\begin{array}{l}\text { Family } X \\
\text { Uave } X \\
\text { Gender } X \\
\text { Pub_Grouth }\end{array}$} \\
\hline & & $\begin{array}{c}\text { Wave X } \\
\text { Pubertal } \\
\text { Growth } \\
\end{array}$ & $\begin{array}{c}\text { Wave } X \\
\text { Child } \\
\text { Sex } \\
\end{array}$ & $\begin{array}{l}\text { Uave X } \\
\text { Family } \\
\text { Iype } \\
\end{array}$ & $\begin{array}{l}\text { Wave X } \\
\text { Pub_Gry } \\
\text { X Gender } \\
\end{array}$ & $\begin{array}{l}\text { Uave X } \\
\text { Pub_Gru } \\
\text { X Family } \\
\end{array}$ & $\begin{array}{l}\text { Uave X } \\
\text { Family X } \\
\text { Gender } \\
\end{array}$ & \\
\hline $\begin{array}{l}\text { Multivariate } F \\
\text { Multivariate } d f\end{array}$ & $\begin{array}{l}124.86 * * * \\
(3,342)\end{array}$ & $\begin{array}{c}1.82 \\
(6,686)\end{array}$ & $\begin{array}{c}-15 \\
(3,342)\end{array}$ & $\begin{array}{c}1.06 \\
(3,342)\end{array}$ & $\begin{array}{c}1.11 \\
(6,686)\end{array}$ & $\begin{array}{c}1.54 \\
(6,686)\end{array}$ & $\begin{array}{c}1.95 \\
(3,342)\end{array}$ & $\begin{array}{c}-81 \\
(6,686)\end{array}$ \\
\hline $\begin{array}{ll}\text { Megativity } & F \\
\text { Positivity } & F \\
\text { Control F } & F \\
\text { Univariate df }\end{array}$ & $\begin{array}{r}259.51^{\star * *} \\
95.60^{\star \star \star} \\
34.28^{\star * *} \\
(1,344)\end{array}$ & $\begin{array}{c}1.37 \\
2.40 \\
1.35 \\
(2.344)\end{array}$ & $\begin{array}{c}.11 \\
.31 \\
.06 \\
(1,344)\end{array}$ & $\begin{array}{c}-49 \\
1.24 \\
1.69 \\
(1,344)\end{array}$ & $\begin{array}{c}1.56 \\
1.78 \\
-03 \\
(2,344)\end{array}$ & $\begin{array}{c}1.50 \\
2.46 \\
-61 \\
(2,344)\end{array}$ & $\begin{array}{c}.85 \\
1.03 \\
4.29 \\
(1,344)\end{array}$ & $\begin{array}{c}1.55 \\
-47 \\
-42 \\
(2,344)\end{array}$ \\
\hline Univariate Findings ${ }^{a}$ & $\begin{array}{l}\text { Main } \\
\text { Effect } \\
\text { for } \\
\text { Wave } \\
\end{array}$ & $\begin{array}{c}\text { Uave X } \\
\text { Pubertal } \\
\text { Growth } \\
\end{array}$ & $\begin{array}{r}\text { Wave } X \\
\text { Child } \\
\text { Sex } \\
\end{array}$ & $\begin{array}{l}\text { Uave } X \\
\text { Family } \\
\text { Type } \\
\end{array}$ & $\begin{array}{l}\text { Wave X } \\
\text { Pub.Grw } \\
\text { X Gender } \\
\end{array}$ & $\begin{array}{l}\text { Wave X } \\
\text { Pub_Grw } \\
\text { X Family }\end{array}$ & $\begin{array}{l}\text { Uave } x \\
\text { Family } x \\
\text { Gender } \\
\end{array}$ & $\begin{array}{l}\text { Fami ly } X \\
\text { Wave } X \\
\text { Gender X } \\
\text { Pub.Growth }\end{array}$ \\
\hline Negativity & $\mathrm{W} 2>\mathrm{H1}$ & - & - & - & - & - & - & - \\
\hline Positivity & U1 > WR & - & - & - & - & - & - & - \\
\hline Control & $H 1>W 2$ & - & - & - & - & - & - & - \\
\hline
\end{tabular}


Table 31 (Continued)

F-Values and Significant Levels for Multivariate Analyses of Mother's Parenting: Repeated Measures from Mothers' Ratings.

Mote: Multivariate test is Pillais.

For Multivariate Tests $=\star p<.05 ; \star \star p<.01 ; \star \star \star p<.001$

For Univariate Tests: $\quad$ - $p<.017 ; \star p_{0}<.003 ; \star \star \star p<.0003$.

square brackets denote univariate results from the multivariate analyses thich had no corresponding multivariate significant effect or interaction.

anivariate tests are follow-up tests based on multivariate results.

These results were based on the univariate sample.

bubertal Growth Group differences are post hoc tests.

Abbreviations

Family Iype: Step = Stepfamily

Mondiv = Nondivorced families

Pubertal Growth Groups: Early-Mid = Early-to-Mid Pubertal Growth Grow

Mo Chng = Mo Change Pubertal Growth Group
Mid-Late = Mid-to-Late Pubertal Growth Group

Waves: $\mathbf{~} 1=$ Wave 1

U2 = Mave 2 
Table 32.

Mothers' Parenting by Differences Scores (Adolescent Ratings): Univariate Means and Standard Deviations.

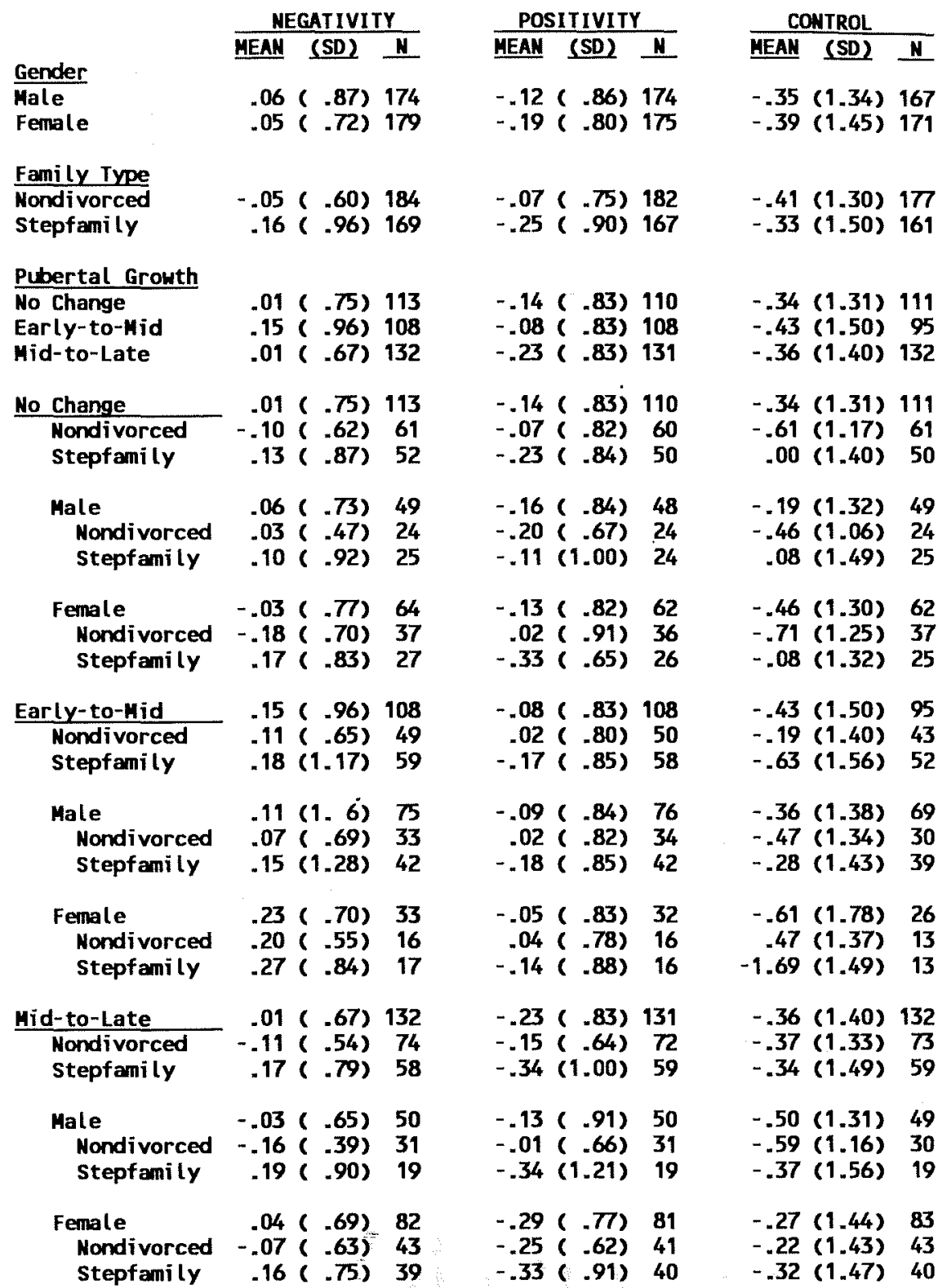


Parent-Adolescent Relations and Puberty

156

Table 33.

F-Values and Significant Levels for Multivariate Analyses of Mother's Parenting: Difference Scores from Adolescents' Ratings.

\begin{tabular}{|c|c|c|c|c|c|c|c|}
\hline \multirow[t]{2}{*}{ Multivariate Tests } & \multicolumn{3}{|c|}{ Main Effects } & \multicolumn{3}{|c|}{ Interactions } & \multirow[b]{2}{*}{$\begin{array}{l}\text { Family X } \\
\text { Gender X } \\
\text { Pub.Growth }\end{array}$} \\
\hline & $\begin{array}{l}\text { Pubertal } \\
\text { Growth } \\
\end{array}$ & $\begin{array}{l}\text { Child } \\
\text { Sex } \\
\end{array}$ & $\begin{array}{l}\text { Family } \\
\text { Iype }\end{array}$ & $\begin{array}{l}\text { Pub.Gru } \\
\times \text { Gender } \\
\end{array}$ & $\begin{array}{l}\text { Pub-Gru } \\
\text { X Family }\end{array}$ & $\begin{array}{l}\text { Family X } \\
\text { Gender }\end{array}$ & \\
\hline $\begin{array}{l}\text { Multivariate } F \\
\text { Multivariate df }\end{array}$ & $\frac{.82}{(6,630)}$ & $\begin{array}{c}-58 \\
(3,314)\end{array}$ & $\begin{array}{c}3,66^{*} \\
(3,314)\end{array}$ & $\begin{array}{c}.59 \\
(6,630)\end{array}$ & $\begin{array}{c}1.88 \\
(6,630)\end{array}$ & $\begin{array}{c}2.25 \\
(3,314)\end{array}$ & $\begin{array}{c}2.14^{\star} \\
(6,630)\end{array}$ \\
\hline $\begin{array}{l}\text { Megativity } F \\
\text { Positivity } F \\
\text { Control F } F \\
\text { Univariate df }\end{array}$ & $\begin{array}{c}1.66 \\
-37 \\
-24 \\
(2.316)\end{array}$ & $\begin{array}{c}-55 \\
1.31 \\
-08 \\
(1,316)\end{array}$ & $\begin{array}{c}6.62^{\star} \\
5.25 \\
.29 \\
(1.316)\end{array}$ & $\begin{array}{c}-76 \\
-20 \\
-81 \\
(2,316)\end{array}$ & $\begin{array}{c}-07 \\
-11 \\
5.67 \\
(2,316)\end{array}$ & $\begin{array}{c}-21 \\
-41 \\
6.46^{*} \\
(1,316)\end{array}$ & $\begin{array}{c}-52 \\
1.54 \\
4.39 * \\
(2,316)\end{array}$ \\
\hline Univariate Findings $^{\mathbf{a}}$ & $\begin{array}{l}\text { Pubertal } \\
\text { Growth }^{\mathbf{b}}\end{array}$ & $\begin{array}{l}\text { Child } \\
\text { Sex }\end{array}$ & $\begin{array}{l}\text { Family } \\
\text { Type }\end{array}$ & $\begin{array}{l}\text { Pub_Gru } \\
\text { X Gender }\end{array}$ & $\begin{array}{l}\text { Pub-Gru } \\
\text { X Family }\end{array}$ & $\begin{array}{l}\text { Family } x \\
\text { Gender }\end{array}$ & $\begin{array}{l}\text { Family } x \\
\text { Gender } x \\
\text { Pub.Growth } \\
\end{array}$ \\
\hline Negativity & n.s. & - & $\begin{array}{l}\text { Step > } \\
\text { Nondiv }\end{array}$ & - & - & - & - \\
\hline Positivity & n.s. & - & - & - & - & - & - \\
\hline Control & n.s. & - & - & - & - & $\begin{array}{l}\text { [Gïrls: } \\
\text { Nondiv } \\
>\text { Step] }\end{array}$ & [See text] \\
\hline
\end{tabular}


Table 34 (Cont inued).

F-Values and Significant Levels for Multivariate Analyses of Mother's Parenting: Difference Scores from Adolescents' Ratings.

Note: Multivariate test is Pillais.

For Multivariate Tests: * $p<.05 ; * 0<.01 ; \star * \neq<<.001$.

For Univariate Tests: $\quad$ p $<.017 ; * \star p<.003 ; \star \star \star p<.0003$.

Square brackets denote univariate results from the multivariate analyses wich had no

corresponding multivariate significant effect or interaction.

anivariate tests are follow-up tests based on multivariate results.

These results were based on the univariate sample.

Abbreviations

Growth Group differences are post hoc tests.

Family Type: Step = Stepfamily

Mondiv = Nondivorced families

Pubertal Growth Groups: Early-Mid = Early-to-Mid Pubertal Growth Group

No Chng = No Change Pubertal Growth Group

Uaves: $\mathbf{H 1}=$ Wave 1

Mid-Late = Mid-to-Late Pubertal Growth Grop

$$
\text { WR }=\text { Have } 2
$$


Table 34.

Fathers' Parenting by Differences Scores (Adolescent Ratings) : Univariate Means and Standard Deviations.

\begin{tabular}{|c|c|c|c|c|c|c|c|c|c|}
\hline & \multicolumn{3}{|c|}{ NEGATIVITY } & \multicolumn{3}{|c|}{ POSITIVITY } & \multicolumn{3}{|c|}{ CONTROL } \\
\hline & MEAN & (SD) & $\mathbf{N}$ & MEAN & (SD) & $N$ & MEAN & (SD) & $\mathbf{N}$ \\
\hline \multicolumn{10}{|l|}{ Gender } \\
\hline $\begin{array}{l}\text { Male } \\
\text { Female }\end{array}$ & $\begin{array}{l}.10 \\
.01\end{array}$ & $\begin{array}{l}(.88) \\
(.72)\end{array}$ & $\begin{array}{l}174 \\
177\end{array}$ & $\begin{array}{r}.03 \\
-.18\end{array}$ & $\begin{array}{l}(.84) \\
(.80)\end{array}$ & $\begin{array}{l}172 \\
174\end{array}$ & $\begin{array}{l}-.41 \\
-.46\end{array}$ & $\begin{array}{l}(1.48) \\
(1.47)\end{array}$ & $\begin{array}{l}165 \\
170\end{array}$ \\
\hline \multicolumn{10}{|l|}{ Family Type } \\
\hline $\begin{array}{l}\text { Nondivorced } \\
\text { Stepfanily }\end{array}$ & $\begin{array}{r}-.05 \\
.17\end{array}$ & $\begin{array}{l}(.58) \\
(.98)\end{array}$ & $\begin{array}{l}183 \\
168\end{array}$ & $\begin{array}{r}.01 \\
-.16\end{array}$ & $\begin{array}{l}(.72) \\
(.92)\end{array}$ & $\begin{array}{l}181 \\
165\end{array}$ & $\begin{array}{l}-.46 \\
-.40\end{array}$ & $\begin{array}{l}(1.28) \\
(1.48)\end{array}$ & $\begin{array}{l}175 \\
160\end{array}$ \\
\hline \multicolumn{10}{|l|}{ Pubertal Growth } \\
\hline $\begin{array}{l}\text { No Change } \\
\text { Early-to-Mid } \\
\text { Mid-to-Late }\end{array}$ & $\begin{array}{l}.02 \\
.12 \\
.03\end{array}$ & $\begin{array}{l}(.80) \\
(.99) \\
(.62)\end{array}$ & $\begin{array}{l}112 \\
108 \\
131\end{array}$ & $\begin{array}{r}-.05 \\
.07 \\
-.22\end{array}$ & $\begin{array}{l}(.78) \\
(.90) \\
(.78)\end{array}$ & $\begin{array}{l}108 \\
108 \\
130\end{array}$ & $\begin{array}{l}-.39 \\
-.49 \\
-.43\end{array}$ & $\begin{array}{l}(1.34) \\
(1.40) \\
(1.40)\end{array}$ & $\begin{array}{r}110 \\
93 \\
132\end{array}$ \\
\hline $\begin{array}{l}\text { No Change } \\
\text { Nondivorced } \\
\text { Stepfamily }\end{array}$ & $\begin{array}{r}.02 \\
-.03 \\
.07\end{array}$ & $\begin{array}{l}(.80) \\
(.58) \\
(1.00)\end{array}$ & $\begin{array}{r}112 \\
61 \\
51\end{array}$ & $\begin{array}{l}-.05 \\
-.02 \\
-.08\end{array}$ & $\begin{array}{l}(.78) \\
(.82) \\
(.74)\end{array}$ & $\begin{array}{r}108 \\
59 \\
49\end{array}$ & $\begin{array}{l}-.39 \\
-.52 \\
-.22\end{array}$ & $\begin{array}{l}(1.34) \\
(1.23) \\
(1.46)\end{array}$ & $\begin{array}{r}110 \\
61 \\
49\end{array}$ \\
\hline $\begin{array}{l}\text { Male } \\
\text { Nondivorced } \\
\text { Stepfamily }\end{array}$ & $\begin{array}{l}.10 \\
.16 \\
.04\end{array}$ & $\begin{array}{l}(.72) \\
(.44) \\
(.91)\end{array}$ & $\begin{array}{l}49 \\
24 \\
25\end{array}$ & $\begin{array}{r}-.06 \\
-.16 \\
.06\end{array}$ & $\begin{array}{l}(.71) \\
(.62) \\
(.79)\end{array}$ & $\begin{array}{l}47 \\
24 \\
23\end{array}$ & $\begin{array}{l}-.23 \\
-.29 \\
-.17\end{array}$ & $\begin{array}{l}(1.30) \\
(1.06) \\
(1.52)\end{array}$ & $\begin{array}{l}49 \\
24 \\
25\end{array}$ \\
\hline $\begin{array}{l}\text { Female } \\
\text { Nondivorced } \\
\text { Stepfani ly }\end{array}$ & $\begin{array}{r}-.05 \\
-.15 \\
.11\end{array}$ & $\begin{array}{l}(.86) \\
(.63) \\
(1.09)\end{array}$ & $\begin{array}{l}63 \\
37 \\
26\end{array}$ & $\begin{array}{r}-.04 \\
.07 \\
-.20\end{array}$ & $\begin{array}{l}(.84) \\
(.94) \\
(.69)\end{array}$ & $\begin{array}{l}61 \\
35 \\
26\end{array}$ & $\begin{array}{l}-.52 \\
-.68 \\
-.27\end{array}$ & $\begin{array}{l}(1.37) \\
(1.33) \\
(1.43)\end{array}$ & $\begin{array}{l}61 \\
37 \\
24\end{array}$ \\
\hline $\begin{array}{l}\text { Early-to-Mid } \\
\text { Nondivorced } \\
\text { Stepfamily }\end{array}$ & $\begin{array}{r}.12 \\
-.02 \\
.23\end{array}$ & $\begin{array}{l}(.99) \\
(.68) \\
(1.18)\end{array}$ & $\begin{array}{r}108 \\
49 \\
59\end{array}$ & $\begin{array}{r}.07 \\
.22 \\
-.06\end{array}$ & $\begin{array}{l}(.90) \\
(.74) \\
(1.01)\end{array}$ & $\begin{array}{r}108 \\
50 \\
58\end{array}$ & $\begin{array}{l}-.49 \\
-.34 \\
-.61\end{array}$ & $\begin{array}{l}(1.40) \\
(1.32) \\
(1.46)\end{array}$ & $\begin{array}{l}93 \\
41 \\
52\end{array}$ \\
\hline $\begin{array}{l}\text { Male } \\
\text { Nondivorced } \\
\text { Stepfami ly }\end{array}$ & $\begin{array}{r}.09 \\
-.05 \\
.19\end{array}$ & $\begin{array}{l}(1.10) \\
(.72) \\
(1.33)\end{array}$ & $\begin{array}{l}75 \\
33 \\
42\end{array}$ & $\begin{array}{l}.14 \\
.29 \\
.02\end{array}$ & $\begin{array}{l}(.92) \\
(.75) \\
(1.03)\end{array}$ & $\begin{array}{l}76 \\
34 \\
42\end{array}$ & $\begin{array}{l}-.48 \\
-.60 \\
-.39\end{array}$ & $\begin{array}{l}(1.31) \\
(1.20) \\
(1.40)\end{array}$ & $\begin{array}{l}67 \\
28 \\
39\end{array}$ \\
\hline $\begin{array}{l}\text { Female } \\
\text { Nondivorced } \\
\text { Stepfani ly }\end{array}$ & $\begin{array}{l}.18 \\
.04 \\
.31\end{array}$ & $\begin{array}{l}(.67) \\
(.60) \\
(.72)\end{array}$ & $\begin{array}{l}33 \\
16 \\
17\end{array}$ & $\begin{array}{r}-.09 \\
.08 \\
-.26\end{array}$ & $\begin{array}{l}(.87) \\
(.73) \\
(.98)\end{array}$ & $\begin{array}{r}32 \\
.16 \\
16\end{array}$ & $\begin{array}{r}-.51 \\
-24 \\
-1.26\end{array}$ & $\begin{array}{l}(1.62) \\
(1.42) \\
(1.49)\end{array}$ & $\begin{array}{l}26 \\
13 \\
13\end{array}$ \\
\hline $\begin{array}{l}\text { Mid-to-Late } \\
\text { Nondivorced } \\
\text { Stepfanily }\end{array}$ & $\begin{array}{r}.03 \\
-.10 \\
.19\end{array}$ & $\begin{array}{l}(.62) \\
(.51) \\
(.71)\end{array}$ & $\begin{array}{r}131 \\
73 \\
58\end{array}$ & $\begin{array}{l}-.22 \\
-.12 \\
-.33\end{array}$ & $\begin{array}{l}(.78) \\
(.59) \\
(.95)\end{array}$ & $\begin{array}{r}130 \\
72 \\
58\end{array}$ & $\begin{array}{l}-.43 \\
-.48 \\
-.37\end{array}$ & $\begin{array}{l}(1.40) \\
(1.31) \\
(1.52)\end{array}$ & $\begin{array}{r}132 \\
73 \\
59\end{array}$ \\
\hline $\begin{array}{l}\text { Male } \\
\text { Nondivorced } \\
\text { Stepfani ly }\end{array}$ & $\begin{array}{r}.11 \\
-.01 \\
.31\end{array}$ & $\begin{array}{l}(.64) \\
(.50) \\
(.80)\end{array}$ & $\begin{array}{l}50 \\
31 \\
19\end{array}$ & $\begin{array}{r}-.05 \\
.04 \\
-.21\end{array}$ & $\begin{array}{l}(.83) \\
(.60) \\
(1.14)\end{array}$ & $\begin{array}{l}49 \\
31 \\
18\end{array}$ & $\begin{array}{l}-.50 \\
-.56 \\
-.41\end{array}$ & $\begin{array}{l}(1.23) \\
(1.19) \\
(1.33)\end{array}$ & $\begin{array}{l}49 \\
30 \\
19\end{array}$ \\
\hline $\begin{array}{l}\text { Female } \\
\text { Nondivorced } \\
\text { Stepfamily }\end{array}$ & $\begin{array}{r}-.02 \\
-.16 \\
.13\end{array}$ & $\begin{array}{l}(.61) \\
(.52) \\
(.67)\end{array}$ & $\begin{array}{r}81 \\
42 \\
39\end{array}$ & $\begin{array}{l}-.32 \\
-.24 \\
-.39\end{array}$ & $\begin{array}{l}(.72) \\
(.56) \\
(.87)\end{array}$ & $\begin{array}{l}81 \\
41 \\
40\end{array}$ & $\begin{array}{l}-.39 \\
-.43 \\
-.35\end{array}$ & $\begin{array}{l}(1.50) \\
(1.40) \\
(1.62)\end{array}$ & $\begin{array}{l}83 \\
43 \\
40\end{array}$ \\
\hline
\end{tabular}


Parent-Adolescent Relations and Puberty

159

Table 35.

F-Values and Significant Levels for Multivariate Analyses of Father's Parenting: Difference Scores from Adolescents' Ratings.

\begin{tabular}{|c|c|c|c|c|c|c|c|}
\hline \multirow{2}{*}{ Multivariate Tests } & \multicolumn{3}{|c|}{ Main Effects } & \multicolumn{4}{|c|}{ Interactions } \\
\hline & $\begin{array}{l}\text { Pubertal } \\
\text { Growth } \\
\end{array}$ & $\begin{array}{l}\text { Child } \\
\text { Sex } \\
\end{array}$ & $\begin{array}{l}\text { Family } \\
\text { Type }\end{array}$ & $\begin{array}{l}\text { Pub.Gru } \\
\text { X Gender }\end{array}$ & $\begin{array}{l}\text { Pub_Gru } \\
\text { X Fanily }\end{array}$ & $\begin{array}{l}\text { Fani ly } x \\
\text { Gender }\end{array}$ & $\begin{array}{l}\text { Familly } x \\
\text { Gender } x \\
\text { Pub.Growth }\end{array}$ \\
\hline $\begin{array}{l}\text { Multivariate } F \\
\text { Multivariate df }\end{array}$ & $\begin{array}{c}.79 \\
(6,618)\end{array}$ & $\begin{array}{c}2.01 \\
(3,308)\end{array}$ & $\begin{array}{c}3.77^{*} \\
(3,308)\end{array}$ & $\begin{array}{c}1.12 \\
(6,618)\end{array}$ & $\begin{array}{c}1.15 \\
(6,618)\end{array}$ & $\begin{array}{c}1.04 \\
(3,308)\end{array}$ & $\begin{array}{c}1.51 \\
(6,618)\end{array}$ \\
\hline $\begin{array}{ll}\text { Negativity } F \\
\text { Positivity } F \\
\text { Control F } \\
\text { Univariate of }\end{array}$ & $\begin{array}{c}.93 \\
1240 \\
.07 \\
(2,310)\end{array}$ & $\begin{array}{c}-14 \\
5.67 \\
-03 \\
(1,310)\end{array}$ & $\begin{array}{c}5.65 \\
6.63^{\star} \\
.12 \\
(1.310)\end{array}$ & $\begin{array}{c}1.40 \\
1.18 \\
-57 \\
(2.310)\end{array}$ & $\begin{array}{c}.92 \\
1.41 \\
1.74 \\
(2,310)\end{array}$ & $\begin{array}{c}.37 \\
1.61 \\
1.84 \\
(1.310)\end{array}$ & $\begin{array}{l}.59 \\
1.12 \\
2.78 \\
(2.310)\end{array}$ \\
\hline Univariate Findings $^{\mathbf{a}}$ & $\begin{array}{l}\text { Pubertal } \\
\text { Growth }^{\mathbf{b}}\end{array}$ & $\begin{array}{l}\text { Child } \\
\text { Sex }\end{array}$ & $\begin{array}{l}\text { Fami ly } \\
\text { Type }\end{array}$ & $\begin{array}{l}\text { Pub_Gru } \\
\text { X Gender }\end{array}$ & $\begin{array}{l}\text { Pub_Gru } \\
\text { X Family }\end{array}$ & $\begin{array}{l}\text { Fani ly } \mathbf{x} \\
\text { Gender }\end{array}$ & $\begin{array}{l}\text { Family } x \\
\text { Gender X } \\
\text { Pub_Growth }\end{array}$ \\
\hline
\end{tabular}

$\begin{array}{lccc}\text { Negativity } & \text { n.s. } & - & - \\ \text { Positivity } & \text { n.s. } & - & \begin{array}{c}\text { Nondiv }> \\ \text { Step }\end{array} \\ \text { Control } & \text { n.s. } & - & -\end{array}$


Table 35.

F-Values and Significant Levels for Multivariate Analyses of Father's Parenting: Difference Scores from Adolescents' Ratings.

Note: Multivariate test is pillais.

For Multivariate Tests: $* p<.05 ; \star * p<.01 ; \star \star \star p<.001$.

For Univariate Tests: $* p<.017 ; * \neq p<.003 ; * * * p<.0003$.

Univariate tests are follow-up tests based on multivariate results.

These results were based on the univariate sample.

bubertal Growth Group differences are post hoc tests.

Abbreviations

Fami ly Iype: Step = Stepfamily Nondiv = Nondivorced families

Pubertal Growth Groups: Early-Mid = Early-to-Mid Pubertal Growth Group

Ho chng = No Change Pubertal Growth Group

Waves: $\begin{aligned} & \text { W1 }=\text { Wave } 1 \\ & \text { UR }=\text { Wave } 2\end{aligned}$

Mid-Late $=$ Mid-to-Late Pubertal Growth Group 
Table 36.

Mothers' Parenting by Adolescents' Report Have 1 and Wave 2 (Repeated Measures) Univariate Means and Standard Deviations.

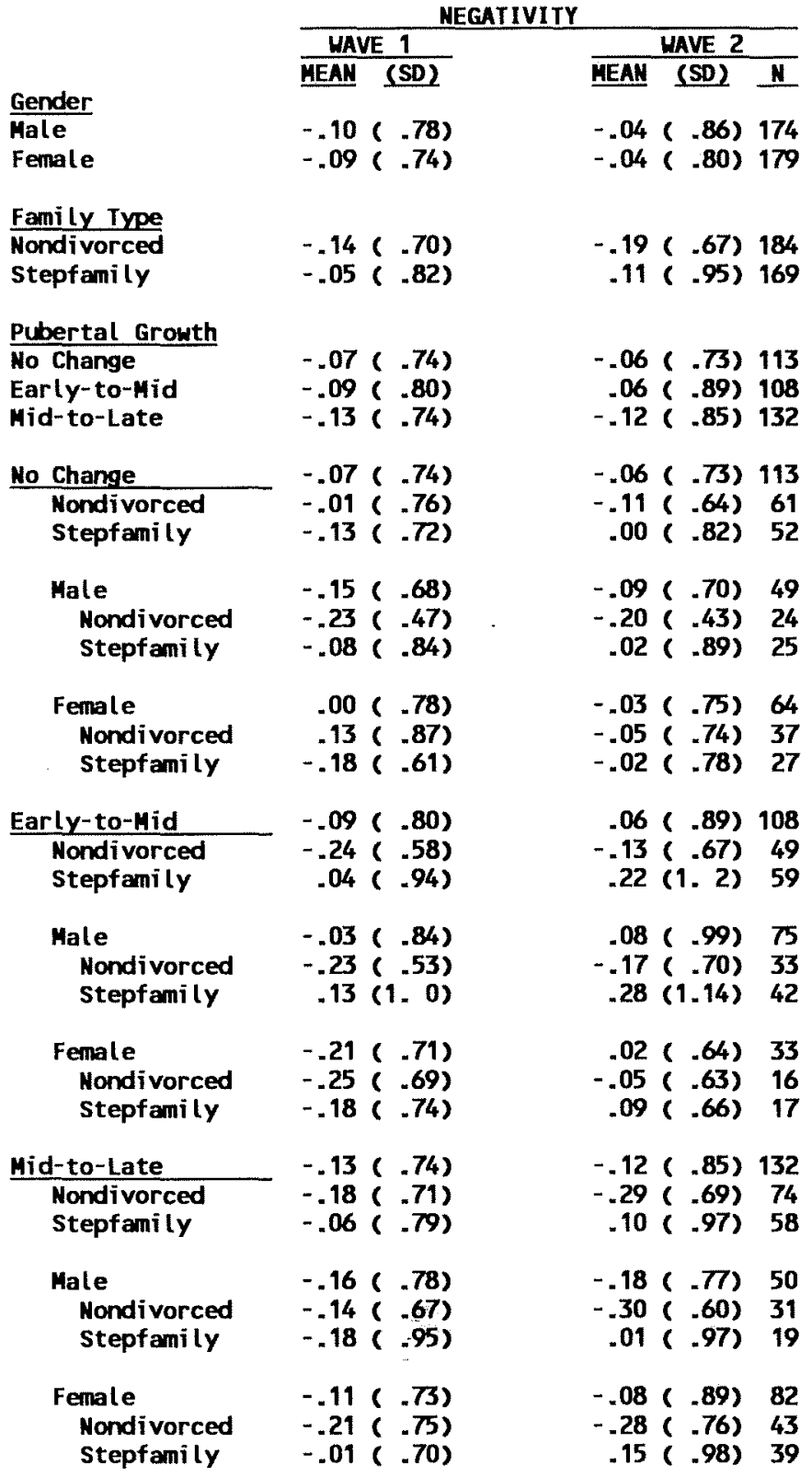


Table 36 (cont inued)

Mothers' Parenting by Adolescents' Report Have 1 and Wave 2 (Repeated Measures) Univariate Means and Standard Deviations.

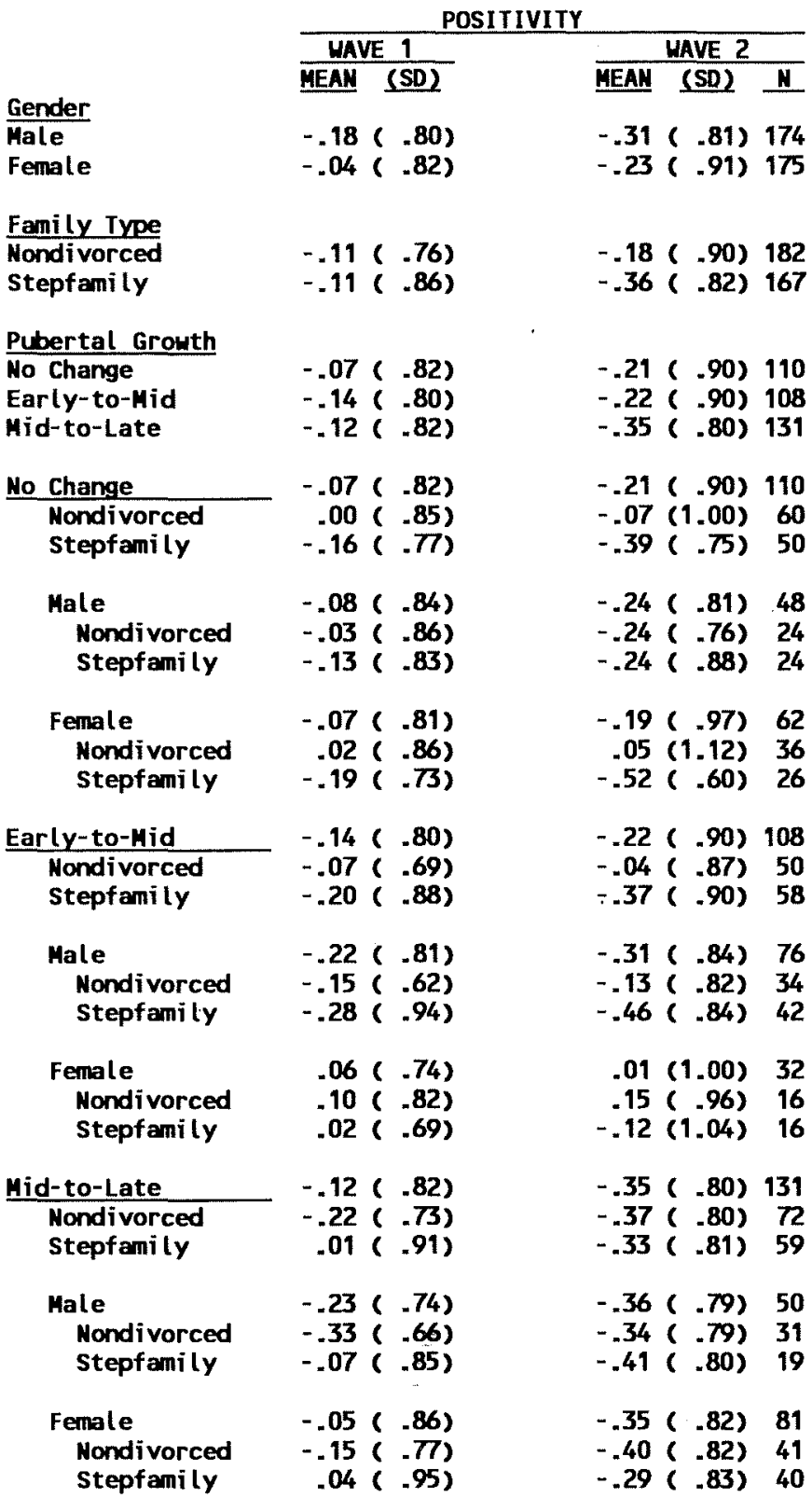


Table 36 (cont inued).

Mothers' Parenting by Adolescents' Report Uave 1 and Nave 2 (Repeated Measures)

Univariate Means and Standard Deviations.

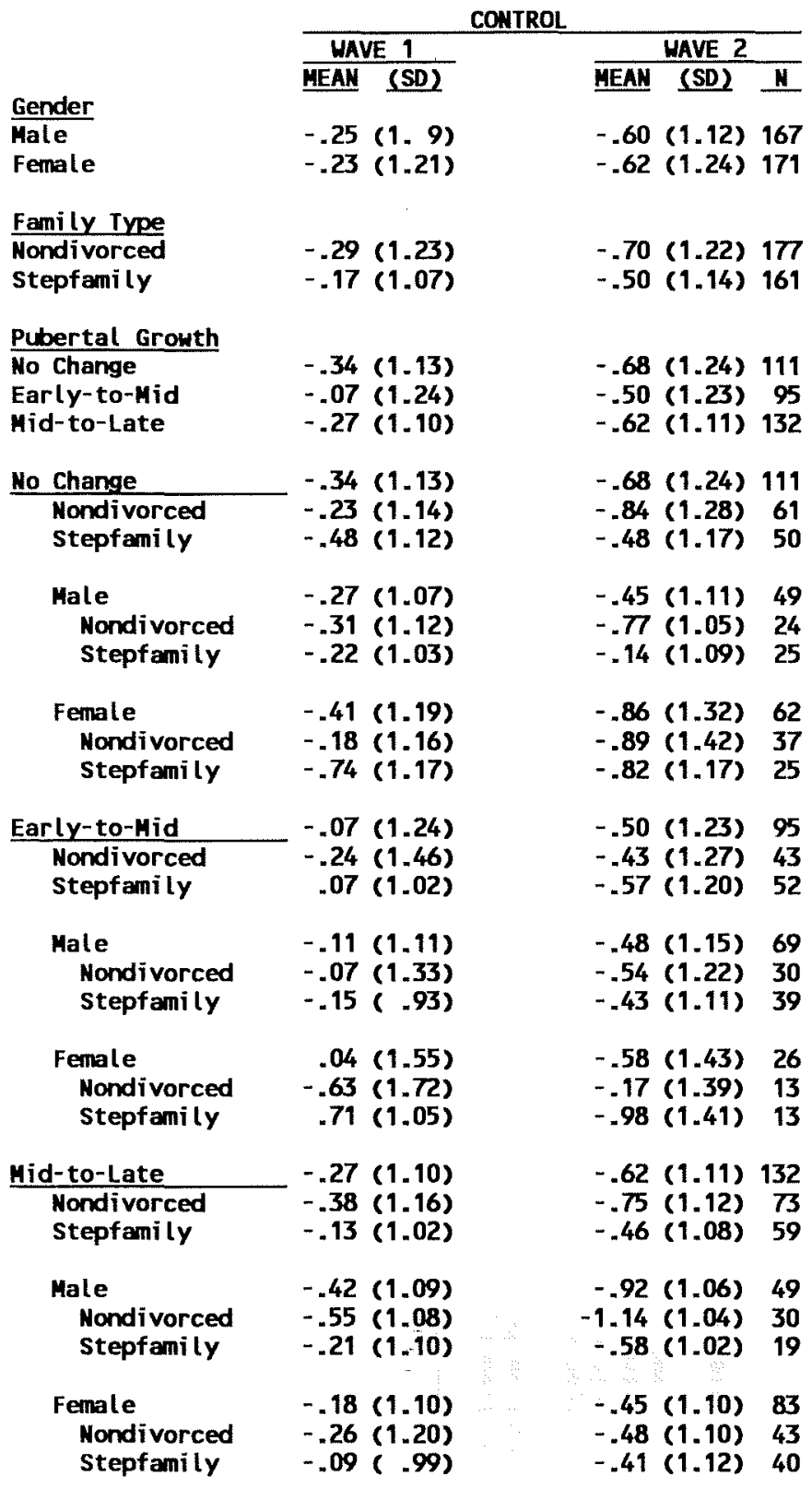




\section{Parent-Adolescent Relations and Puberty}

Table 37.

F-Values and Significant Levels for Multivariate Analyses of Mother's Parenting: Repeated Measures from Adolescents' Ratings

\begin{tabular}{|c|c|c|c|c|c|c|c|}
\hline \multirow[t]{2}{*}{ Multivariate Tests } & \multicolumn{3}{|c|}{ Main Effects } & \multicolumn{4}{|c|}{ Interactions } \\
\hline & $\begin{array}{l}\text { Pubertal } \\
\text { Growth }\end{array}$ & $\begin{array}{l}\text { Child } \\
\text { Sex } \\
\end{array}$ & $\begin{array}{l}\text { Family } \\
\text { Iype }\end{array}$ & $\begin{array}{l}\text { Pub_Gru } \\
\text { X Gender }\end{array}$ & $\begin{array}{l}\text { Pub_Gru } \\
\text { X Family }\end{array}$ & $\begin{array}{l}\text { Fanily } x \\
\text { Gender } \\
\end{array}$ & $\begin{array}{l}\text { Family X } \\
\text { Gender X } \\
\text { Pub_Growth }\end{array}$ \\
\hline $\begin{array}{l}\text { Multivariate } F \\
\text { Multivariate df }\end{array}$ & $\begin{array}{c}-81 \\
(6,630)\end{array}$ & $\frac{-65}{(3,314)}$ & $\begin{array}{c}2.76^{*} \\
(3,314)\end{array}$ & $\begin{array}{c}1.14 \\
(6,630)\end{array}$ & $\begin{array}{c}1.11 \\
(6,630)\end{array}$ & $\begin{array}{c}-73 \\
(3,314)\end{array}$ & $\begin{array}{c}1.14 \\
(6,630)\end{array}$ \\
\hline $\begin{array}{l}\text { Negativity } F \\
\text { Positivity } \\
\text { Control F } \\
\text { Univariate df }\end{array}$ & $\begin{array}{c}-44 \\
-48 \\
1.61 \\
(2,316)\end{array}$ & $\begin{array}{c}-09 \\
1.61 \\
-01 \\
(1,316)\end{array}$ & $\begin{array}{l}4.11 * \\
1.99 \\
2.09 \\
(1,316)\end{array}$ & $\begin{array}{c}-46 \\
-72 \\
2.43 \\
(2,316)\end{array}$ & $\begin{array}{c}-80 \\
2.17 \\
-90 \\
(2,316)\end{array}$ & $\begin{array}{c}1.39 \\
-20 \\
.95 \\
(1,316)\end{array}$ & $\begin{array}{c}1.30 \\
.68 \\
1.58 \\
(2,316)\end{array}$ \\
\hline Univariate Findings $^{\text {a }}$ & $\begin{array}{l}\text { Pubertal } \\
\text { Growth }^{6}\end{array}$ & $\begin{array}{l}\text { Child } \\
\text { Sex } \\
\end{array}$ & $\begin{array}{l}\text { Family } \\
\text { Iype }\end{array}$ & $\begin{array}{l}\text { Pub.Gru } \\
\text { X Gender }\end{array}$ & $\begin{array}{l}\text { Pub_Gru } \\
\text { X Family }\end{array}$ & $\begin{array}{l}\text { Fami ly } x \\
\text { Gender } \\
\end{array}$ & $\begin{array}{l}\text { Family } x \\
\text { Gender } x \\
\text { Pub.Growth } \\
\end{array}$ \\
\hline Megativity & n.s. & - & $\begin{array}{l}\text { Step > } \\
\text { Nondiv }\end{array}$ & - & - & - & - \\
\hline Positivity & n.s. & - & - & - & - & - & - \\
\hline Control & n.s. & - & - & - & - & - & - \\
\hline
\end{tabular}


Table 37 (Cont inued).

F-Values and Significant Levels for Multivariate Analyses of Mother's

Parenting: Repeated Measures from Adolescents' Ratings

\begin{tabular}{|c|c|c|c|c|c|c|c|c|}
\hline \multirow[b]{2}{*}{ Multivariate Tests } & \multirow[b]{2}{*}{$\begin{array}{l}\text { Main } \\
\text { Effect } \\
\text { for } \\
\text { Uave } \\
\end{array}$} & \multicolumn{6}{|c|}{ Interactions with Wave Effects } & \multirow[b]{2}{*}{$\begin{array}{l}\text { Family } X \\
\text { Uave } X \\
\text { Gender } X \\
\text { Pub_Growth } \\
\end{array}$} \\
\hline & & $\begin{array}{c}\text { Mave X } \\
\text { Pubertal } \\
\text { Growth } \\
\end{array}$ & $\begin{array}{r}\text { Wave } x \\
\text { Child } \\
\text { Sex } \\
\end{array}$ & $\begin{array}{l}\text { Wave X } \\
\text { Fami ly } \\
\text { Iype } \\
\end{array}$ & $\begin{array}{l}\text { Wave X } \\
\text { Pub.Grw } \\
X \text { Gender } \\
\end{array}$ & $\begin{array}{l}\text { Uave X } \\
\text { Pub.Gru } \\
\text { X Family }\end{array}$ & $\begin{array}{l}\text { Wave } X \\
\text { Family } x \\
\text { Gender } \\
\end{array}$ & \\
\hline $\begin{array}{l}\text { Multivariate } F \\
\text { Multivariate of }\end{array}$ & $\begin{array}{l}11,70^{\star \star \star} \\
(3,3-2)\end{array}$ & $\begin{array}{c}-82 \\
(6,630)\end{array}$ & $\begin{array}{c}.58 \\
(3,314)\end{array}$ & $\begin{array}{c}3.66^{*} \\
(3,314)\end{array}$ & $\begin{array}{c}-60 \\
(6,630)\end{array}$ & $\begin{array}{c}1.87 \\
(6,630)\end{array}$ & $\begin{array}{l}2.25 \\
(3,314)\end{array}$ & $\begin{array}{l}2.14^{*} \\
(6,630)\end{array}$ \\
\hline $\begin{array}{l}\text { Negativity } F \\
\text { Positivity } F \\
\text { Control F } \\
\text { Univariate df }\end{array}$ & $\begin{array}{l}4.15 \\
12.87^{\star \star \star} \\
22.64^{\star \star \star} \\
(1,316)\end{array}$ & $\begin{array}{c}1.65 \\
.36 \\
.78 \\
(2,316)\end{array}$ & $\begin{array}{c}.55 \\
1.31 \\
.08 \\
(1,316)\end{array}$ & $\begin{array}{c}6.62^{\star} \\
5.25 \\
.29 \\
(1,316)\end{array}$ & $\begin{array}{c}.76 \\
-20 \\
-81 \\
(2,316)\end{array}$ & $\begin{array}{c}.07 \\
-11 \\
5.66^{*} \\
(2,316)\end{array}$ & $\begin{array}{c}.21 \\
-41 \\
6.47^{*} \\
(1,-44)\end{array}$ & $\begin{array}{c}.52 \\
1.54 \\
4.39 * \\
(2,316)\end{array}$ \\
\hline$\underline{\text { Univariate Findings }}^{\mathrm{a}}$ & $\begin{array}{l}\text { Main } \\
\text { Effect } \\
\text { for } \\
\text { Wave } \\
\end{array}$ & $\begin{array}{c}\text { Wave } X \\
\text { Pubertal } \\
\text { Growth } \\
\end{array}$ & $\begin{array}{c}\text { Wave } X \\
\text { Child } \\
\text { Sex } \\
\end{array}$ & $\begin{array}{l}\text { Wave } X \\
\text { Fami ly } \\
\text { Type } \\
\end{array}$ & $\begin{array}{l}\text { Wave X } \\
\text { Pub.Gru } \\
\text { X Gender } \\
\end{array}$ & $\begin{array}{l}\text { Wave X } \\
\text { Pub.Gru } \\
\text { X Fanily } \\
\end{array}$ & $\begin{array}{l}\text { Wave } X \\
\text { Fami ly } x \\
\text { Gender } \\
\end{array}$ & $\begin{array}{l}\text { Family } X \\
\text { Mave } X \\
\text { Gender } X \\
\text { Pub_Growth } \\
\end{array}$ \\
\hline Negativity & - & - & - & $\begin{array}{l}\text { w1: Ster } \\
>\text { Mondiy }\end{array}$ & p & - & - & - \\
\hline Positivity & $\mathrm{w1}_{1}>\mathrm{H2}$ & - & - & - & - & - & - & - \\
\hline Control & u1 > & - & - & - & - & $\begin{array}{l}\text { [UR } \\
\text { Ho Chng: } \\
\text { Mondiv > } \\
\text { Step] }\end{array}$ & $\begin{array}{l}\text { [W2 Girls: } \\
\text { Nondiv } \\
>\text { Stepl }\end{array}$ & [See text] \\
\hline
\end{tabular}


Table 37 (Cont inued).

F-Values and Significant Levels for Multivariate Analyses of Mother's

Parenting: Repeated Measures from Adolescents" Ratings

Mote: Multivariate test is Pillais.

For Multivariate Tests: $* p<.05 ; \approx * p<.01 ; \star \star \star * p<.001$.

For Univariate Tests: $\quad p<.017 ; \star * \neq<.003 ; \star \star \star \neq<<.0003$.

square brackets denote univariate results from the multivariate analyses which had no corresponding multivariate significant effect or interaction.

univariate tests are follow-up tests based on multivariate results.

These results were based on the univariate sample.

bubertal Growth Group differences are post hoc tests.

\section{Abbreviations}

Fami ly Type: Step = Stepfamily

Mondiv = Mondivorced famil ies

Pubertal Growth Groups: Early-Mid = Early-to-Mid Pubertal Growth Group

$$
\text { No Chng = No Change Pubertal Growth Group }
$$

Uaves: $41=$ Wave 1

Mid-Late $=$ Mid-to-Late Pubertal Growth Group

$$
\text { U2 = Uave } 2
$$


Table 38 .

Fathers' Parenting by Adolescents' Report Wave 1 and Wave 2 (Repeated Measures) Univariate Means and Standard Deviations.

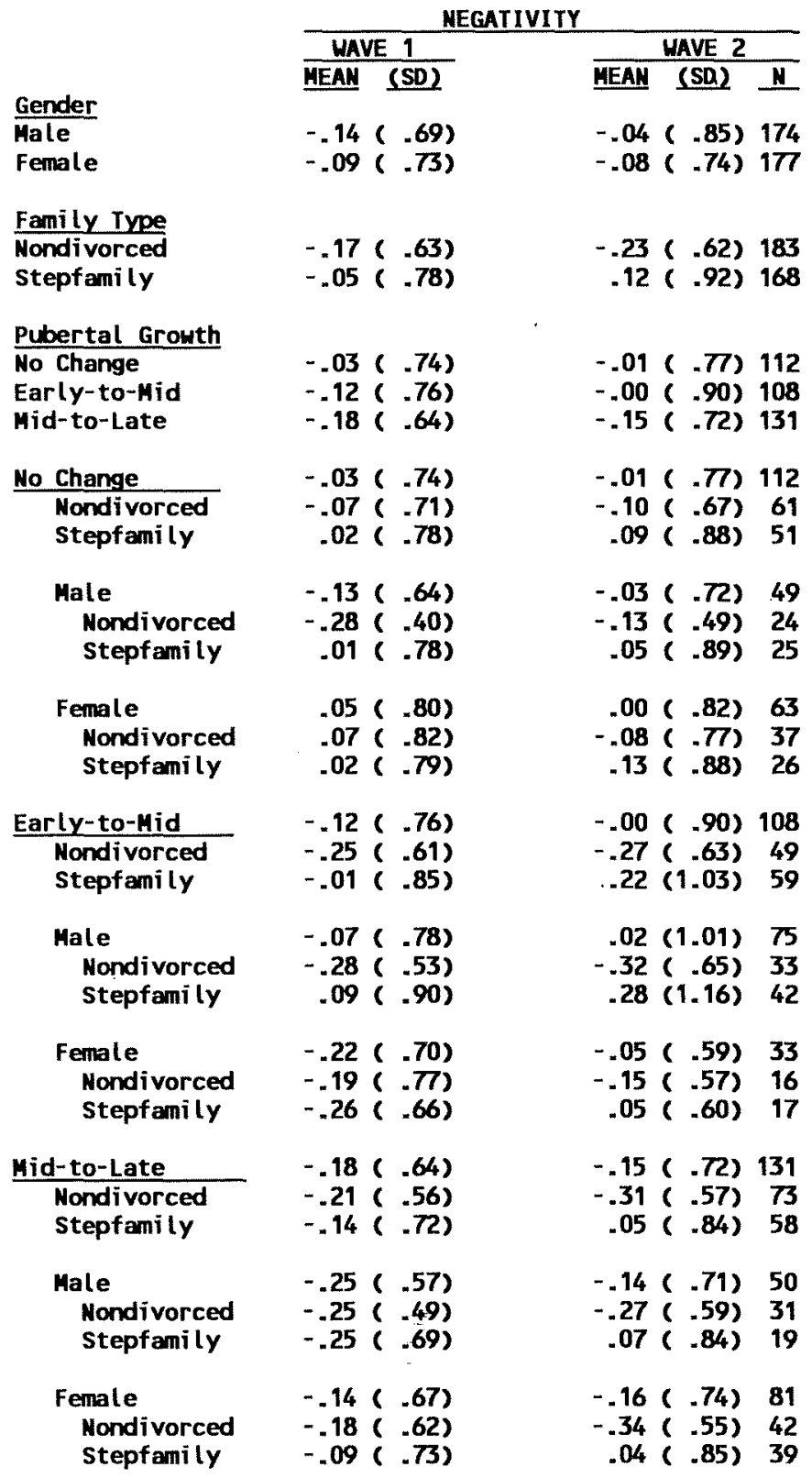


Table 38 (Cont inued).

Fathers' Parenting by Adolescents' Report Mave 1 and Mave 2 (Repeated Measures) Univariate Means and Standard Deviations.

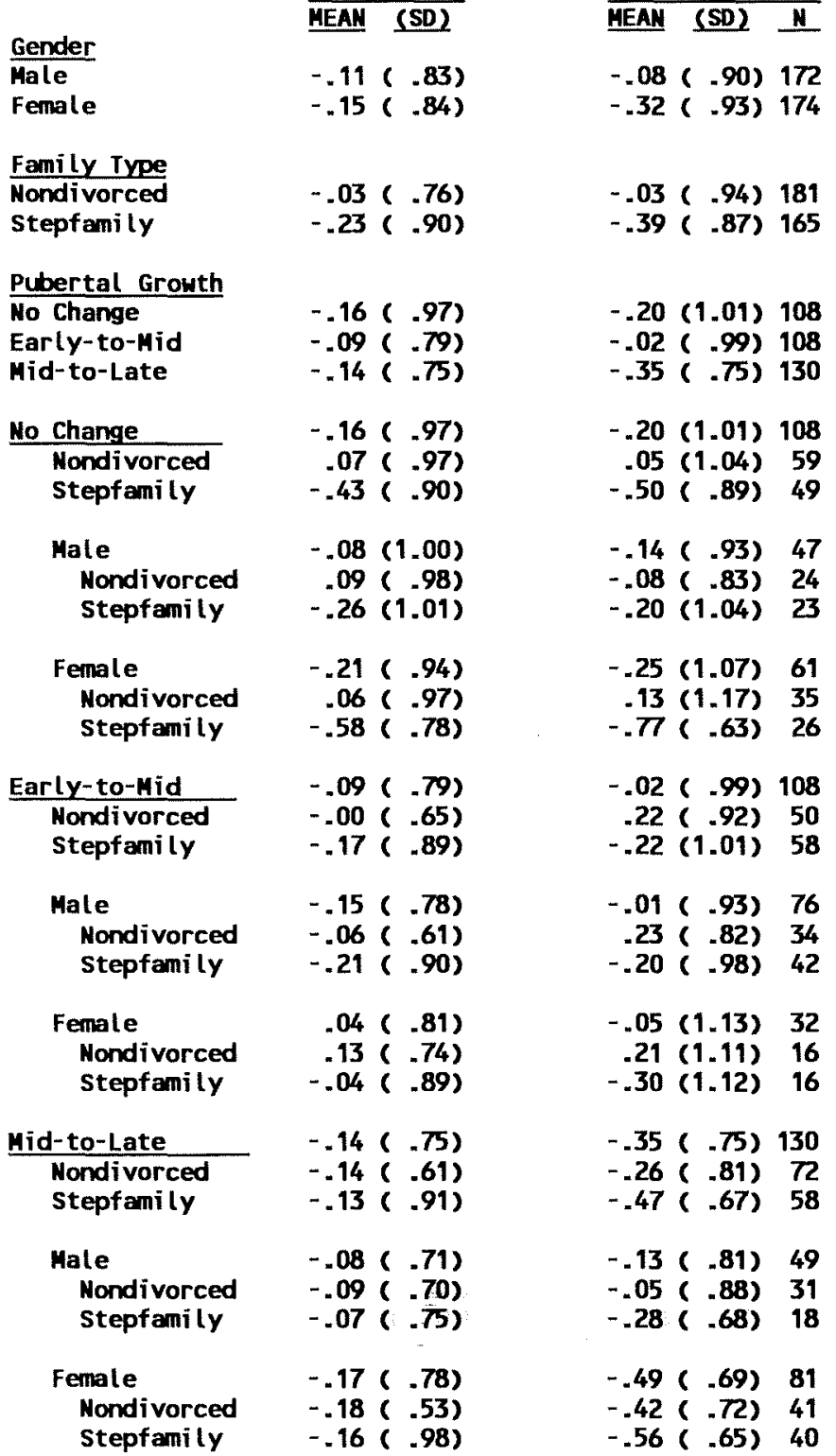


Table 38 (Cont inued).

Fathers' Parenting by Adolescents' Report Wave 1 and Wave 2 (Repeated Measures) Univariate Means and Standard Deviations.

\begin{tabular}{|c|c|c|c|c|}
\hline & & & & \\
\hline & WAVE 1 & & UAVE 2 & \\
\hline & MEAN (SD) & MEAN & (SD) & N \\
\hline Gender & & & & \\
\hline Male & $-.23(1.07)$ & -.64 & $(1.16)$ & 165 \\
\hline Female & $-.21(1.17)$ & -.67 & $(1.22)$ & 170 \\
\hline Family Type & & & & \\
\hline Nondivorced & $-.26(1.17)$ & -.73 & $(1.19)$ & 175 \\
\hline Stepfamily & $-.18(1.07)$ & -.58 & $(1.19)$ & 160 \\
\hline Pubertal Growth & & & & \\
\hline No Change & $-.28(1.10)$ & -.67 & $(1.28)$ & 110 \\
\hline Early-to-Mid & $-.03(1.15)$ & -.52 & $(1.20)$ & 93 \\
\hline Mid-to-Late & $-.30(1.11)$ & -.74 & $(1.11)$ & 132 \\
\hline No Change & $-.28(1.10)$ & -.67 & $(1.28)$ & 110 \\
\hline Nond ivorced & $-.19(1.09)$ & -.71 & $(1,26)$ & 61 \\
\hline Stepfamily & $-.41(1.12)$ & & $(1.51)$ & 49 \\
\hline Male & $-.25(1.08)$ & -.48 & $(1.21)$ & 49 \\
\hline Nondivorced & $-.35(1.08)$ & -.64 & $(1.11)$ & 24 \\
\hline Stepfanily & $-.15(1.09)$ & -.32 & $(1.30)$ & 25 \\
\hline Female & $-.31(1.13)$ & -.83 & $(1.32)$ & 61 \\
\hline Nondivorced & $-.08(1.10)$ & -.76 & $(1.36)$ & 37 \\
\hline Stepfamily & $-.67(1.11)$ & -.95 & $(1.27)$ & 24 \\
\hline Early-to-Mid & $-.03(1.15)$ & -.52 & $(1.20)$ & 93 \\
\hline Nondivorced & $-.11(1.27)$ & -.44 & $(1.22)$ & 41 \\
\hline Stepfami ly & $.03(1.06)$ & -.57 & $(1.19)$ & 52 \\
\hline Male & $-.07(1.06)$ & -.55 & $(1.18)$ & 67 \\
\hline Nondivorced & $.05(1.11)$ & -.55 & $(1.14)$ & 28 \\
\hline Stepfami l & $-.15(1.02)$ & -.54 & $(1.22)$ & 39 \\
\hline Female & $.07(1.39)$ & -.43 & $(1.26)$ & 26 \\
\hline Nondivorced & $-.45(1.55)$ & -.21 & $(1.40)$ & 13 \\
\hline Stepfamily & $.60(1.01)$ & -.66 & $(1.12)$ & 13 \\
\hline Mid-to-Late & $-.30(1.11)$ & -.74 & (1.11) & 132 \\
\hline Nondivorced & $-.41(1.18)$ & -.90 & $(1.09)$ & 73 \\
\hline Step & $-.17(1.01)$ & -.54 & (1.11) & 59 \\
\hline Male & $-.44(1.08)$ & -.94 & $(1.04)$ & 49 \\
\hline $\begin{array}{l}\text { Nondivorced } \\
\text { Stenfamily }\end{array}$ & $\begin{array}{l}-.63(1.11) \\
-.15(98)\end{array}$ & $\begin{array}{r}-1.19 \\
-56\end{array}$ & $(1.01)$ & $\begin{array}{l}30 \\
10\end{array}$ \\
\hline step & $\begin{array}{c}-.15<=98 \\
-\end{array}$ & -.3 & 1.003 & 19 \\
\hline Female & $-.22(1.12)$ & -.62 & $(1.13)$ & 83 \\
\hline $\begin{array}{l}\text { Nondivorced } \\
\text { Stepfami ly }\end{array}$ & $\begin{array}{l}-.26(1.21) \\
-.18(1.03)\end{array}$ & $\begin{array}{l}-.69 \\
-.53\end{array}$ & $\begin{array}{l}(1.11) \\
(1.17)\end{array}$ & $\begin{array}{l}43 \\
40\end{array}$ \\
\hline & & & & \\
\hline
\end{tabular}


Parent-Adolescent Relations and Puberty

170

Table 39.

F-Values and Significant Levels for Multivariate Analyses of Father's Parenting: Repeated Measures from Adolescents' Ratings-

\begin{tabular}{|c|c|c|c|c|c|c|c|}
\hline & \multicolumn{3}{|c|}{ Main Effects } & \multicolumn{3}{|c|}{ Interactions } & \multirow{3}{*}{$\begin{array}{l}\text { Fani ly X } \\
\text { Gender X } \\
\text { Pub_Growth }\end{array}$} \\
\hline & $\begin{array}{l}\text { Pubertal } \\
\text { Growth }\end{array}$ & $\begin{array}{l}\text { Child } \\
\text { Sex } \\
\end{array}$ & $\begin{array}{l}\text { Family } \\
\text { Type } \\
\end{array}$ & $\begin{array}{l}\text { Pub.Grw } \\
\mathrm{X} \text { Gender }\end{array}$ & $\begin{array}{l}\text { Pub.Gru } \\
\text { X Family }\end{array}$ & $\begin{array}{l}\text { Fanily } x \\
\text { Gender }\end{array}$ & \\
\hline \multicolumn{7}{|l|}{$\therefore 8$} & \\
\hline $\begin{array}{l}\text { Multivariate } F \\
\text { Multivariate off }\end{array}$ & $\begin{array}{c}1.45 \\
(6,618)\end{array}$ & $\begin{array}{c}-80 \\
(3,308)\end{array}$ & $\begin{array}{l}7.42 \star \star \star \\
(3,308)\end{array}$ & $\begin{array}{c}1.38 \\
(6,618)\end{array}$ & $\begin{array}{c}.88 \\
(6,618)\end{array}$ & $\begin{array}{c}1.21 \\
(3,308)\end{array}$ & $\begin{array}{c}1.56 \\
(6,618)\end{array}$ \\
\hline $\begin{array}{ll}\text { Negativity } & F \\
\text { Positivity } & F \\
\text { Control } F \\
\text { Univariate of }\end{array}$ & $\begin{array}{c}1.29 \\
.77 \\
3.01 \\
(2.310)\end{array}$ & $\begin{array}{c}-09 \\
1.42 \\
-16 \\
(1,310)\end{array}$ & $\begin{array}{c}6.36^{\star} \\
12.17^{\star \star} \\
-77 \\
(1,310)\end{array}$ & $\begin{array}{c}-78 \\
-68 \\
1.90 \\
(2,310)\end{array}$ & $\begin{array}{c}-.03 \\
2.04 \\
1.56 \\
(2,310)\end{array}$ & $\begin{array}{c}1.86 \\
1.57 \\
-85 \\
(1,310)\end{array}$ & $\begin{array}{c}1.44 \\
.89 \\
1.94 \\
(2.310)\end{array}$ \\
\hline \multicolumn{8}{|l|}{ Univariate Findings ${ }^{a}$} \\
\hline & $\begin{array}{l}\text { Pubertal } \\
\text { Growth }_{b}\end{array}$ & $\begin{array}{l}\text { Child } \\
\text { Sex } \\
\end{array}$ & $\begin{array}{l}\text { Family } \\
\text { Type } \\
\end{array}$ & $\begin{array}{l}\text { Pub.Gru } \\
\text { X Gender }\end{array}$ & $\begin{array}{l}\text { Pub_Grw } \\
\text { X Family }\end{array}$ & $\begin{array}{l}\text { Fami ly } x \\
\text { Gender }\end{array}$ & $\begin{array}{l}\text { Fanily X } \\
\text { Gender X } \\
\text { Pub_Growth }\end{array}$ \\
\hline Megativity & n.s. & - & $\begin{array}{l}\text { Step > } \\
\text { Mondiv }\end{array}$ & - & - & - & - \\
\hline Positivity & n.s. & - & $\begin{array}{l}\text { Mondiv > } \\
\text { Step }\end{array}$ & - & - & - & - \\
\hline Control & n.s. & - & - & - & - & - & - \\
\hline
\end{tabular}


Table 39 (continued).

F-Values and Significant Levels for Multivariate Analyses of Father's Parenting: Repeated Measures from Adolescents' Ratings

\begin{tabular}{|c|c|c|c|c|c|c|c|c|}
\hline \multirow[b]{2}{*}{ Multivariate Tests } & \multirow[b]{2}{*}{$\begin{array}{l}\text { Main } \\
\text { Effect } \\
\text { for } \\
\text { Uave } \\
\end{array}$} & \multicolumn{6}{|c|}{ Interactions with Uave Effects } & \multirow[b]{2}{*}{$\begin{array}{l}\text { Fani Iy X } \\
\text { Uave X } \\
\text { Gender X } \\
\text { Pub.Growth }\end{array}$} \\
\hline & & $\begin{array}{l}\text { Uave } X \\
\text { Pubertal } \\
\text { Growth }\end{array}$ & $\begin{array}{c}\text { Wave } X \\
\text { Child } \\
\text { Sex } \\
\end{array}$ & $\begin{array}{l}\text { Uave } X \\
\text { Fami ly } \\
\text { Type } \\
\end{array}$ & $\begin{array}{l}\text { Wave X } \\
\text { Pub.Gru } \\
\text { X Gender }\end{array}$ & $\begin{array}{l}\text { Uave X } \\
\text { Pub_Gru } \\
\text { X Fanily }\end{array}$ & $\begin{array}{l}\text { Uave } x \\
\text { Fami ly } x \\
\text { Gender } \\
\end{array}$ & \\
\hline $\begin{array}{l}\text { Multivariate } F \\
\text { Multivariate df }\end{array}$ & $\begin{array}{l}10,42^{\star * * *} \\
(3,308)\end{array}$ & $\begin{array}{c}-79 \\
(6,618)\end{array}$ & $\begin{array}{c}2.01 \\
(3,308)\end{array}$ & $\begin{array}{c}3.77^{*} \\
(3,308)\end{array}$ & $\begin{array}{c}1.12 \\
(6,618)\end{array}$ & $\begin{array}{c}1.14 \\
(6,618)\end{array}$ & $\begin{array}{c}1,04 \\
(3,308)\end{array}$ & $\begin{array}{c}1.51 \\
(6,618)\end{array}$ \\
\hline $\begin{array}{ll}\text { Megativity } & F \\
\text { Positivity } & F \\
\text { Control } & F \\
\text { Univariate } & \text { df }\end{array}$ & $\begin{array}{l}3.87 \\
3.27 \\
27.65^{\star \star \star} \\
(1,310)\end{array}$ & $\begin{array}{c}.93 \\
1.23 \\
.07 \\
(2,310)\end{array}$ & $\begin{array}{c}-14 \\
5.67 \\
.03 \\
(1,310)\end{array}$ & $\begin{array}{c}5.64 \\
6.63^{\star} \\
-12 \\
(1,310)\end{array}$ & $\begin{array}{c}1.40 \\
1.17 \\
-57 \\
(2,310)\end{array}$ & $\begin{array}{c}-92 \\
1.41 \\
1.74 \\
(2,310)\end{array}$ & $\begin{array}{c}-37 \\
1.61 \\
1.84 \\
(1,310)\end{array}$ & $\begin{array}{c}.59 \\
1.12 \\
2.78 \\
(2,310)\end{array}$ \\
\hline Univariate Findings ${ }^{a}$ & $\begin{array}{l}\text { Main } \\
\text { Effect } \\
\text { for } \\
\text { Uave } \\
\end{array}$ & $\begin{array}{c}\text { Wave } X \\
\text { Pubertal } \\
\text { Grouth } \\
\end{array}$ & $\begin{array}{c}\text { Wave } X \\
\text { Child } \\
\text { Sex } \\
\end{array}$ & $\begin{array}{l}\text { Wave } x \\
\text { Family } \\
\text { Type } \\
\end{array}$ & $\begin{array}{l}\text { Wave X } \\
\text { Pub_Grw } \\
X \text { Gender }\end{array}$ & $\begin{array}{l}\text { Wave } X \\
\text { Pub.Gru } \\
\text { X Family }\end{array}$ & $\begin{array}{l}\text { Uave X } \\
\text { Fani ly X } \\
\text { Gender } \\
\end{array}$ & $\begin{array}{l}\text { Fani ly } x \\
\text { Wave } x \\
\text { Gender } x \\
\text { Pub_Growth }\end{array}$ \\
\hline Megativity & - & - & - & - & - & - & - & - \\
\hline Positivity & - & - & - & $\begin{aligned} \text { H2: } & \text { Mond } \\
& >\text { Step }\end{aligned}$ & liv & - & - & - \\
\hline Control & $H_{1}>W_{2}$ & - & - & - & - & - & - & - \\
\hline
\end{tabular}


Table 39 (cont inued).

F-Values and Significant Levels for Multivariate Analyses of Father's Parenting: Repeated Measures from Adolescents' Ratings.

Note: Multivariate test is Pillais.

For Multivariate Tests: ${ }^{*} p<.05 ; \star \star * p<.01 ; \star \star \star p<.001$.

For Univariate Tests: $\quad p<.017 ; \star \star p<.003 ; \star \star \star * p<.0003$

aUnivariate tests are follow-up tests based on multivariate results.

These results were based on the univariate sample.

bpubertal Growth Group differences are post hoc tests.

Abbrevīations

Fani ly Type: Step = Stepfamily

Nondiv = Mondivorced families

Pubertal Growth Groups: Early-Mid = Early-to-Mid Pubertal Growth Group

Ho Chng = No Change Pubertal Growth Group

Waves: $\mathrm{H}_{\mathrm{H}}=$ Wave 1

Mid-Late = Mid-to-Late Pubertal Growth Group 
Table 40.

Mothers' Parenting Related to Pubertal Timing for Girls (Repeated Measures) Univar iate Means and Standard Deviations.

\begin{tabular}{|c|c|c|c|}
\hline & \multicolumn{3}{|c|}{ NEGATIVITY } \\
\hline & WAVE 1 & \multicolumn{2}{|l|}{ HAVE 2} \\
\hline & MEAN (SD) & MEAN (SD) & $\mathbf{N}$ \\
\hline \multicolumn{4}{|l|}{ Fanily Type } \\
\hline Nondivorced & $-.13(-45)$ & $.05(.46)$ & 72 \\
\hline Stepfanily & $-.03(.55)$ & $.20(.49)$ & 51 \\
\hline \multicolumn{4}{|l|}{ Pubertal Timing } \\
\hline Early Development & $-.17(.36)$ & $.04(.39)$ & 30 \\
\hline On-Time Development & $-.03(.57)$ & $.17(.54)$ & 61 \\
\hline Late Development & $-.12(.47)$ & $.07(.42)$ & 32 \\
\hline \multicolumn{4}{|l|}{ Early Development } \\
\hline Nondivorced & $-.21(.34)$ & $-.01(.31)$ & 17 \\
\hline Stepfamily & $-.13(.39)$ & $.11(.48)$ & 13 \\
\hline \multicolumn{4}{|l|}{ On-Time Development } \\
\hline $\begin{array}{l}\text { Nondivorced } \\
\text { Stepfamily }\end{array}$ & $\begin{array}{r}-.17(.51) \\
.14(.59)\end{array}$ & $\begin{array}{l}.04(.55) \\
.31(.51)\end{array}$ & $\begin{array}{l}33 \\
28\end{array}$ \\
\hline \multicolumn{4}{|l|}{ Late Development } \\
\hline $\begin{array}{l}\text { Nondivorced } \\
\text { Stepfani ly }\end{array}$ & $\begin{array}{l}-.02(-45) \\
-.35(-.46)\end{array}$ & 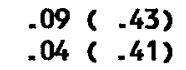 & $\begin{array}{l}22 \\
10\end{array}$ \\
\hline
\end{tabular}

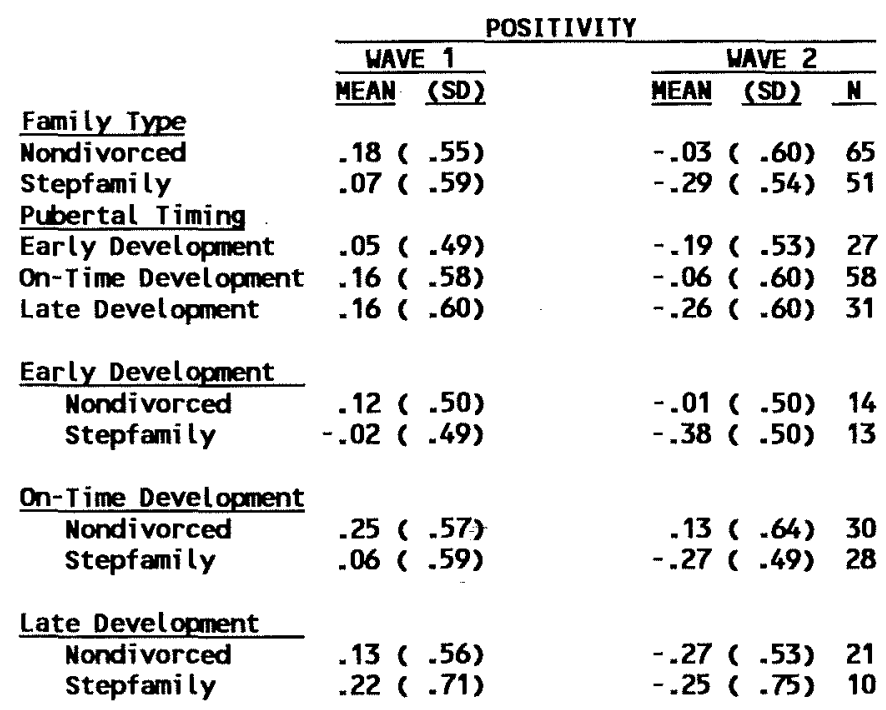


Table 40 (continued)

Mothers' Parenting Related to Pubertal Timing for Girls (Repeated Measures)

Univariate Means and Standard Deviations.

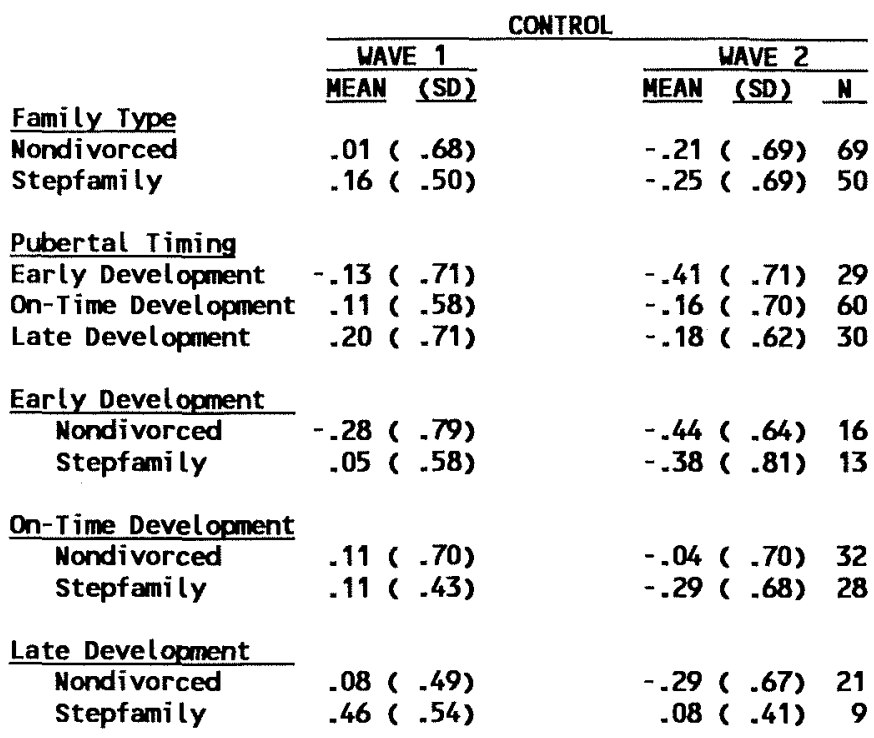


Table 41.

F-Values and Significant Levels for Multivariate Analyses of Mother's Parenting Related to Pubertal Timing Groups (Composite Scores).

\begin{tabular}{|c|c|c|c|c|c|c|c|}
\hline \multirow[t]{2}{*}{ Multivariate Tests } & \multicolumn{3}{|c|}{ Main Effects } & \multicolumn{4}{|c|}{ Interactions } \\
\hline & $\begin{array}{l}\text { Pubertal } \\
\text { Timing } \\
\end{array}$ & $\begin{array}{l}\text { Fanily } \\
\text { Type }\end{array}$ & Yave & $\begin{array}{c}\text { Pubertal } \\
\text { Timing } \\
\times \quad \text { Fam.Type } \\
\end{array}$ & $\begin{array}{l}\text { Pubertal } \\
\text { Timing } \\
\text { by Uave }\end{array}$ & $\begin{array}{l}\text { Family } \\
\text { Type } \\
\text { by Have }\end{array}$ & $\begin{array}{l}\text { Pubertal } \\
\text { Timing } \\
\text { by Fam. Type } \\
\text { by Uave } \\
\end{array}$ \\
\hline 4 & & & $\cdot$ & & & & . \\
\hline $\begin{array}{l}\text { Multivariate } F \\
\text { Multivariate df }\end{array}$ & $\begin{array}{c}1.98 \\
(6,208)\end{array}$ & $\begin{array}{c}2.21 \\
(3,103)\end{array}$ & $\begin{array}{l}36.09 * * * \\
(3,103)\end{array}$ & $\begin{array}{c}1.56 \\
(6,208)\end{array}$ & $\begin{array}{c}-87 \\
(6,208)\end{array}$ & $\begin{array}{c}2.00 \\
(3,103)\end{array}$ & $\begin{array}{c}-74 \\
(6,208)\end{array}$ \\
\hline $\begin{array}{ll}\text { Negativity } & F \\
\text { Positivity } & F \\
\text { Control } & F \\
\text { Univariate } & \text { df }\end{array}$ & $\begin{array}{c}1.73 \\
-56 \\
3.49 \\
(2,105)\end{array}$ & $\begin{array}{c}-32 \\
2.32 \\
2.19 \\
(1.105)\end{array}$ & $\begin{array}{l}27.55^{\star \star \star \star} \\
41.48^{\star \star \star} \\
20.38^{\star * \star} \\
(1.105)\end{array}$ & $\begin{array}{l}1.78 \\
2.06 \\
1.73 \\
(2.105)\end{array}$ & $\begin{array}{c}-20 \\
2.19 \\
-36 \\
(2.105)\end{array}$ & $\begin{array}{c}-91 \\
4.12 \\
1.63 \\
(1.105)\end{array}$ & $\begin{array}{c}1.33 \\
.36 \\
-36 \\
(2,105)\end{array}$ \\
\hline Univariate Findings & & & & & & & \\
\hline Negativity & - & - & $\mathbf{U}>\mathbf{Y 1}$ & - & - & - & - \\
\hline Positivity & - & - & $\mathrm{H} 1>\mathrm{H2}$ & - & - & - & - \\
\hline Control & - & - & $\mathrm{u} 1>\mathrm{u} 2$ & - & - & - & - \\
\hline
\end{tabular}

Mote: Multivariate test is Pillais.

For Multivariate Tests: $* p<.05 ; \star \star * p<.01 ; \star \star \star * p<.001$

For Univariate Tests: $\quad \neq p<.017 ; \star \star p<.003 ; \star \star \star p<.0003$. 
Table 42.

Fathers' Parenting Related to Pubertal Timing for Girls (Repeated Measures) Univariate Means and Standard Deviations.

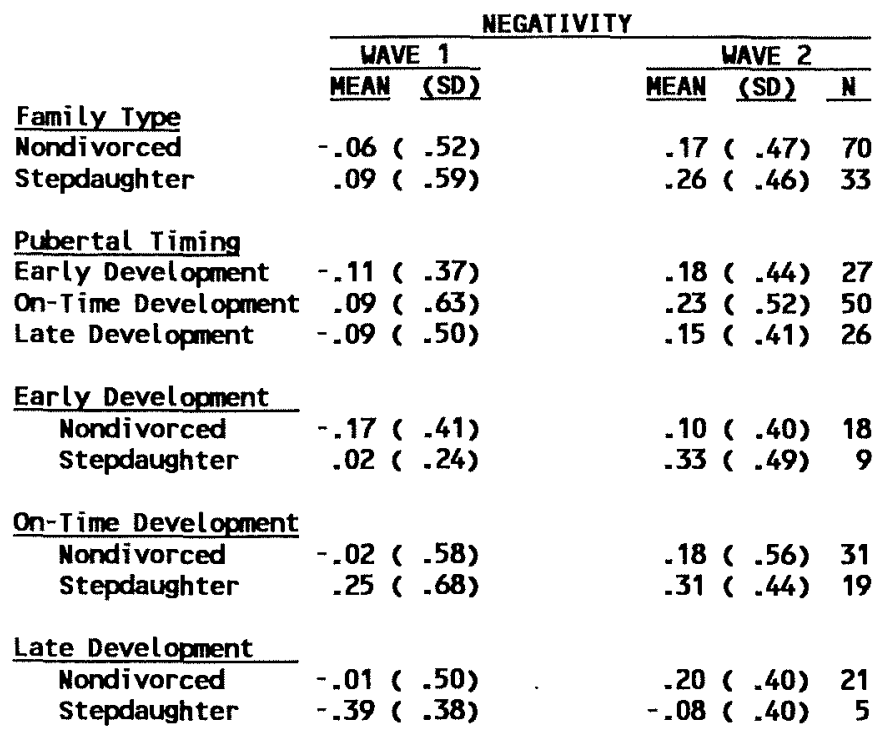

\begin{tabular}{|c|c|c|c|}
\hline & \multicolumn{3}{|c|}{ POSITIVITY } \\
\hline & WAVE 1 & \multicolumn{2}{|l|}{ WAVE 2} \\
\hline & MEAN (SD) & MEAN (SD) & $\mathbf{N}$ \\
\hline \multicolumn{4}{|l|}{ Fanily Type } \\
\hline $\begin{array}{l}\text { Nondivorced } \\
\text { Stepdaughter }\end{array}$ & $\begin{array}{r}.08(.53) \\
-.39(.64)\end{array}$ & $\begin{array}{l}-.09(.58) \\
-.58(.45)\end{array}$ & $\begin{array}{l}64 \\
32\end{array}$ \\
\hline \multicolumn{4}{|l|}{ Pubertal Timing } \\
\hline $\begin{array}{l}\text { Early Development } \\
\text { On-T ime Devel opment } \\
\text { Late Development }\end{array}$ & $\begin{array}{l}-.17(.56) \\
-.09(.65) \\
.03(.57)\end{array}$ & $\begin{array}{l}-.34(.53) \\
-.21(.63) \\
-.25(.56)\end{array}$ & $\begin{array}{l}23 \\
48 \\
25\end{array}$ \\
\hline \multicolumn{4}{|l|}{ Early Development } \\
\hline $\begin{array}{l}\text { Nondivorced } \\
\text { Stepdaughter }\end{array}$ & $\begin{array}{l}-.05(.50) \\
-.39(.63)\end{array}$ & $\begin{array}{l}-.18(.51) \\
-.64(.44)\end{array}$ & $\begin{array}{r}15 \\
8\end{array}$ \\
\hline \multicolumn{4}{|l|}{ On-Time Development } \\
\hline $\begin{array}{l}\text { Nondivorced } \\
\text { Stepdaughter }\end{array}$ & $\begin{array}{r}.22(.51) \\
-.61(.52)\end{array}$ & $\begin{array}{r}.08(.60) \\
-.69(.33)\end{array}$ & $\begin{array}{l}30 \\
18\end{array}$ \\
\hline \multicolumn{4}{|l|}{ Late Development } \\
\hline $\begin{array}{l}\text { Nondivorced } \\
\text { Stepdaughter }\end{array}$ & $\begin{array}{r}-.05(.56) \\
.26(.61)\end{array}$ & $\begin{array}{l}-.27(.55) \\
-.17(.62)\end{array}$ & $\begin{array}{r}19 \\
6\end{array}$ \\
\hline
\end{tabular}


Table 42 (cont inued).

Fathers' Parenting Related to Pubertal Timing for Girls (Repeated Measures)

Univariate Means and Standard Deviations.

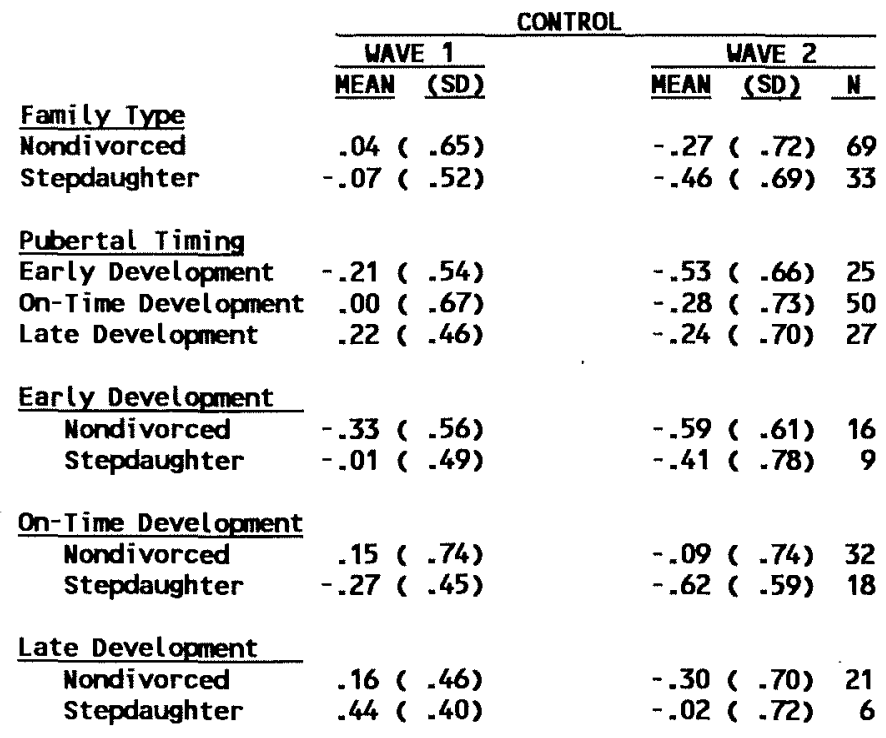


Parent-Adolescent Relations and Puberty

178

Table 43.

F-Values and Significant Levels for Multivariate Analyses of Father's Parenting Related to Pubertal Timing Groups (Composite Scores).

\begin{tabular}{|c|c|c|c|c|c|c|c|}
\hline \multirow{2}{*}{ Multivariate Iests } & \multicolumn{3}{|c|}{ Main Effects } & \multicolumn{4}{|c|}{ Interactions } \\
\hline & $\begin{array}{l}\text { Pubertal } \\
\text { Iiming }\end{array}$ & $\begin{array}{l}\text { Family } \\
\text { Iype }\end{array}$ & Have & $\begin{array}{c}\text { Pubertal } \\
\text { Timing } \\
\times \text { Fam_Type } \\
\end{array}$ & $\begin{array}{l}\text { Pubertal } \\
\text { Timing } \\
\text { by Mave }\end{array}$ & $\begin{array}{l}\text { Family } \\
\text { Type } \\
\text { by Wave }\end{array}$ & $\begin{array}{l}\text { Pubertal } \\
\text { Timing } \\
\text { by Fam.Type } \\
\text { by Uave }\end{array}$ \\
\hline $\begin{array}{l}\text { Multivariate } F \\
\text { Multivariate df }\end{array}$ & $\begin{array}{l}1.81 \\
(6,168)\end{array}$ & $\begin{array}{c}3.25 \\
(3,83)\end{array}$ & $\begin{array}{l}36 .-9 * * * \\
(3,83)\end{array}$ & $\begin{array}{l}2.66 \\
(6,168)\end{array}$ & $\begin{array}{l}1.41 \\
(6,168)\end{array}$ & $\begin{array}{c}-80 \\
(3,83)\end{array}$ & $(6,168)$ \\
\hline $\begin{array}{ll}\text { Megativity } & F \\
\text { Positivity } & F \\
\text { Control } F \\
\text { Univariate df }\end{array}$ & $\begin{array}{c}1.81 \\
1.39 \\
2.75 \\
(2.85)\end{array}$ & $\begin{array}{c}.15 \\
8.34 * \\
-18 \\
(1,85)\end{array}$ & $\begin{array}{l}27 .-5^{\star \star \star} \\
41 .-8^{\star \star \star} \\
20 .-8^{\star \star \star} \\
(1,85)\end{array}$ & $\begin{array}{c}2.41 \\
5.19^{\star} \\
3.36 \\
(2.85)\end{array}$ & $\begin{array}{r}1.70 \\
2.52 \\
-11 \\
(2,85)\end{array}$ & $\begin{array}{c}.01 \\
2.02 \\
-42 \\
(1,85)\end{array}$ & $\begin{array}{c}-48 \\
1.27 \\
-14 \\
(2,85)\end{array}$ \\
\hline
\end{tabular}

Univariate Findings

Negativity

$-\quad$ WR > U1

Positivity

Nondiv >

$w 1>M R$ Not Oun

[On-Time:

Nondiv >

Control

H1 > U2 
Table 43 (Cont inued).

F-Values and Significant Levels for Multivariate Analyses of Father's Parenting Related to Pubertal Timing Groups (Composite Scores).

Note: Multivariate test is Pillais.

For Multivariate Tests: $* p<.05 ; * * p<.01 ; * \star * p<.001$.

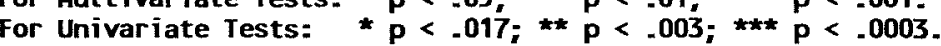

aFamily Type is Nondivorced versus Stepfather-stepdaughter dyads.

Abbreviations: Nondiv = Mondivorced family

Not $\mathrm{Om}=$ Stepfather-stepdaughter dyads

Early = Early Pubertal Development

On-Time = On-Time Pubertal Development

Late = Late Pubertal Development

W1 $=$ Mave 1

U2 = Have 2 